\title{
Estudios epidérmicos en helechos y licófitas medicinales de la Provincia de Córdoba, Argentina
}

\author{
María Claudia Luján ${ }^{1,2}$, Rita Morero ${ }^{1}$ y Gloria Estela Barboza ${ }^{1}$
}

Recibido: 30.12.2009; aceptado: 29.12.2011

\begin{abstract}
Epidermal studies in medicinal ferns and lycophytes from Córdoba Province, Argentina). An epidermal analysis of vegetative and reproductive organs of 28 medicinal ferns from Córdoba Province (Argentina) has been carried out. The objectives were: a) to characterize in detail the epidermis of the organs; b) to contribute to the delimitation at specific level in cases of close morphological similarities; c) to provide additional information for a quality control of the commercialized ferns. Hair types, scales, microscales, respiratory structures, and epidermal cells features are described in detail. For each taxon, a description with illustrations and photographs are provided. Trichomes and type of stomata are novel data for some taxa. From a taxonomical point of view, indument and stomata types were the most significant characters to differentiate the taxa. The contribution to the quality control is summarized in the differential key and the iconography that allow the identification of a vegetal drug when it is fragmented or powered.
\end{abstract}

Key words: hairs, microscales, quality control, scales, stomata

RESUMEN - (Estudios epidérmicos en helechos y licófitas medicinales de Provincia de Córdoba, Argentina). Se realiza un análisis epidérmico de los órganos vegetativos y reproductivos de 28 helechos y licófitas medicinales, que crecen en Córdoba (Argentina). Los objetivos fueron: a) caracterizar en detalle la epidermis de todos los órganos; b) contribuir a la diferenciación de taxones estrechamente relacionados y c) proveer información adicional para un adecuado control de calidad de los helechos medicinales que se comercializan. Se describen en detalle distintos tipos de pelos, escamas, microescamas, estructuras de respiración y características de las células epidérmicas. Para cada taxón, se provee una descripción acompañada de dibujos lineales y fotomicrografías. Se describen por primera vez pelos y escamas inéditos y se mencionan tipos de estomas novedosos en varios taxones. Desde el punto de vista taxonómico, el indumento y los tipos de estomas fueron los caracteres más significativos para diferenciar taxones. El aporte al control de calidad queda resumido en los caracteres diagnósticos de la clave y en la iconografía que permiten la identificación de una especie cuando la droga vegetal se encuentra fragmentada o pulverizada.

Palabras clave: control de calidad, escamas, estomas, microescamas, pelos

\section{Introducción}

La Provincia de Córdoba (Argentina) presenta, dada su ubicación geográfica, una marcada heterogeneidad de sus ambientes donde la riqueza de helechos y licófitas es relevante, comparable al centro de diversidad de la región templada sur de Argentina y Chile (90 especies), propuesto por Ponce et al. (2002). La diversidad de estos grupos en Córdoba está representada por 86 taxones específicos e infraespecíficos (Arana et al. 2004, Morero et al. 2006), siendo predominantemente elementos andino-pampeanos.
Para Argentina se citan 56 taxones de helechos y licófitas que son empleados con fines medicinales (Barboza et al. 2009, Martínez 2010), de los cuales 33 habitan en Córdoba. Todos ellos son de uso popular y sólo Equisetum giganteum y Dryopteris filix-mas son reconocidos como droga oficial (Farmacopea Argentina 1978) o como medicamento fitoterápico (Disposición 2673/99, ANMAT).

El uso de los helechos como plantas medicinales se conoce desde el pasado remoto. Así, Dioscórides, que vivió en el siglo I de nuestra Era, en su tratado "Ciencia Médica", dio ya a conocer los usos medicinales de Dryopteris filix-mas, especie incorporada actualmente

1. Instituto Multidisciplinario de Biología Vegetal (CONICET-UNC) y Facultad Ciencias Químicas (UNC), Casilla de Correo 495, 5000 Córdoba, Argentina

2. Autor correspondiente: clujan@imbiv.unc.edu.ar 
en muchas farmacopeas del mundo por sus propiedades vermífugas (Font Quer 1993). En la Edad Media, era habitual relacionar la morfología de los soros con órganos humanos, para cuyas afecciones se creía que la planta poseía virtudes curativas (Salvo-Tierra 1990). Desde ese entonces, con el transcurso del tiempo, se ha generado una extensa literatura especializada sobre el tema. En Sudamérica, numerosas publicaciones han contribuido al conocimiento de los helechos medicinales de distintos países; cabe mencionar a Murillo (1983) quien hace especial referencia a los usos de los helechos de Colombia, a Looser \& Rodrígues (2004), quienes describen los propiedades y nombres vulgares de especies medicinales chilenas y a Navarrete et al. (2006), por presentar información sobre los usos atribuidos a Pteridofitas de Ecuador, Bolivia y Perú.

Numerosos trabajos aportan información sobre el tema para Argentina. La obra Plantae Diaphoricae Florae Argentinae (Hieronymus 1882) merece especial referencia por ser uno de los primeros antecedentes bibliográficos, en el que se registran ca. 30 entidades, preferentemente del centro y norte de Argentina. Asimismo, pueden destacarse las floras medicinales de Córdoba (Barboza et al. 2006) y Mendoza (Roig 2002), las contribuciones florísticas regionales de Martínez Crovetto (1981a, b), Bianco \& Cantero (1988), Hurrell \& Sota (1996), Lahitte et al. (1998) y trabajos que abordan aspectos etnobotánicos de los helechos en diferentes comunidades nativas (Conticello et al. 1997, Filipov 1997)

Dada la importancia de estas plantas en etnomedicina y las frecuentes adulteraciones de las que han sido objeto (Luján et al. 2000, 2007, Luján \& Barboza 2008) es indispensable aportar herramientas idóneas que permitan la correcta identificación de las especies, tanto de los órganos enteros como fragmentados.

En este grupo de plantas, los atributos morfo-anatómicos de los órganos vegetativos y estructuras reproductivas tienen un significativo valor como caracteres diagnósticos de identificación. La gran diversidad de pelos y escamas que protegen los ejes caulinares y a otros órganos (pecíolos, láminas, ejes foliares), es de gran importancia en la sistemática de los helechos, mereciendo especial atención (Sota 1977, Lavalle \& Rodríguez 2010, Sundue 2010, Sundue et al. 2010). De igual modo, los tipos de estomas pueden ser un valioso elemento para estimar las relaciones entre familias, géneros y especies (Van Cotthem 1970a, b, 1973).
Si bien existen obras clásicas que brindan información sobre la anatomía de los helechos (Ogura 1972, Gifford \& Foster 1989, Strasburger et al. 1994) y estudios que comprenden algunas familias y géneros de Pteridófitas de Argentina (Di Fulvio 1956, Sota 1960, Giúdice \& Nieto 1994, Giúdice 1999, Luján et al. 2000, Lavalle \& Rodríguez 2010), aún la información disponible es incompleta y las ilustraciones son escasas.

En el presente trabajo se estudiaron 28 taxones de helechos y licófitas con los siguientes objetivos: a) caracterizar en detalle la epidermis de todos los órganos; b) contribuir a la diferenciación de taxones estrechamente relacionados y c) proveer información adicional para un adecuado control de calidad de los helechos medicinales que se comercializan. Quedan excluidos los 5 taxones conocidos como "helechos machos" que forman parte de otra contribución (Pacciaroni et al. 2009).

\section{Materiales y métodos}

Se procedió a la búsqueda y recolección de materiales vivos en varios viajes de campo a distintos departamentos de Córdoba. Los ejemplares que documentan estos estudios fueron depositados en el herbario del Museo Botánico de Córdoba (CORD); también se consultaron ejemplares de otros herbarios cuando fue necesario (RCV, RIOC). Se trabajó con material fresco, fijado en formalina aceto-alcohólica (FAA) al $50 \%$ y con material seco previamente hidratado con detergente diluido al $70 \%$ y sometido a un ligero hervor. Las observaciones se realizaron directamente sobre el órgano (especialmente para observar escamas) o, tras previa diafanización, siguiendo la técnica de D`Ambrogio de Argüeso (1986). Se efectuaron preparaciones histoquímicas con diferentes ensayos de tinción: azul de algodón, safranina, sudán III, lugol y eosina, en preparaciones temporarias montadas en glicerina acuosa al 50\%.

Para probar los caracteres morfohistológicos, se analizaron 10 muestras comerciales de distintos laboratorios comerciales de los helechos y licófitas que se expenden en Córdoba. Estas muestras están depositadas en el herbario CORD.

Para la terminología específica se siguieron las acepciones de Lellinger (2002). Dada la alta variabilidad que presentan los pelos, se clasificaron según el criterio de Payne (1978), Theobald et al. (1979) y Di Fulvio \& Dottori (1995). En cambio, las escamas no pudieron ser tipificadas debido a la amplia 
variación cuantitativa y cualitativa que exhiben estos apéndices, aún en el mismo ejemplar. Se analizaron pelos y escamas epidérmicas en diferentes estructuras vegetativas y reproductivas, recurriendo a ejemplares muy jóvenes, cuando fue necesario (ej. Anemia australis, Cheilanthes obducta). En pocas situaciones se tuvo en cuenta la longitud de estos apéndices, ya que en la mayoría de los casos, varía durante el desarrollo del tricoma.

Para los estomas, se utilizó la clasificación de Van Cotthem (1970 a, b, 1973) y de Fryns-Claessens \& Van Cotthem (1973); cuando fue necesario, se recurrió a la tipología de Wilkinson (1979) y Sen \& De (1992).

Las ilustraciones son originales; los dibujos se realizaron con cámara clara y las fotomicrografías se tomaron con microscopio óptico Axiophot Zeiss.

La selección de los taxones medicinales incluidos en este trabajo está basada en el Catálogo de plantas medicinales de Argentina (Barboza et al. 2009), donde puede consultarse información sobre los órganos empleados y uso medicinal para cada especie.

En la tabla 1 están ordenados los taxones, por familia en forma alfabética, siguiendo la clasificación propuesta por Sylvestre \& Ponce (2008), salvo cambios producidos posteriormente en algunos grupos (Smith et al. 2006).

Respecto a los estudios epidérmicos de Anemia, se describe e ilustra en detalle A. australis y se compara con $A$. tomentosa. De igual modo se procedió con las variedades de Argyrochosma nivea, habiéndose dibujado solamente Argyrochosma nivea var. nivea

\section{Resultados}

Se presentan en cuatro secciones: 1) Clasificación y descripción de los tricomas; 2) Estructuras de ventilación; 3) Descripción de la epidermis de cada órgano (trofofilo, esporofilo, vaina foliar, fronde, tallo aéreo y rizoma) por especie, detallando características de las células epidérmicas propiamente dichas, estomas, otras estructuras de aireación e indumento. Las especies se presentan siguiendo el orden alfabético de las familias; 4) Clave diferencial de las especies basada en caracteres epidérmicos diagnósticos para un control de calidad.

Clasificación y descripción de los tricomas - Se clasifican en escamas y pelos. Las escamas y los pelos son apéndices epidérmicos que muestran amplia variabilidad. Difieren entre sí, en la forma, tamaño y organización celular. Mientras que los pelos son más simples, uni-pluricelulares, filiformes o, a veces, ramificados, las escamas son generalmente apéndices laminares de mayor tamaño y con estructura celular más compleja.

ESCAMAS - Con mayor frecuencia, las escamas o páleas se ubican en el rizoma y cubriendo la porción basal del pecíolo (Adiantum spp., Adiantopsis chlorophyla); también pueden localizarse en los raquis (Blechnum hastatum, Cheilanthes myriophylla) y en la superficie de las láminas enteras (Elaphoglossum gayanum) o en los segmentos foliares (Pleopeltis pinnatifida). Se disponen imbricadamente cubriendo toda la superficie de los rizomas, o regularmente esparcidas en las hojas.

Las escamas exhiben amplia variación en su forma, estructura, margen, tamaño y tipos de inserción. También se observaron microescamas que son mucho más pequeñas que las escamas, constituidas por una o varias series de células, con paredes engrosadas y pigmentadas; en ocasiones, estas microescamas son ramificadas y con extremos globosos.

Teniendo en cuenta estos atributos se pueden distinguir algunos tipos de escamas y microescamas que son característicos y constantes en ciertos géneros o especies (figuras 1, 2 y descripciones por especie).

PELOS - Se diferenciaron 3 tipos básicos de pelos: eglandulares, glandulares y de aspecto escamoso.

Pelos eglandulares - Pueden ser unicelulares o pluricelulares (simples, estrellados, dendroides y ramificados). Según su forma, se distinguen en:

Unicelulares cónicos: Variables en rigidez y longitud; pueden ser rectos (figura 4 D) o curvos (figura $7 \mathrm{G}$ ), con la base algo ensanchada (figura $5 \mathrm{M}$ ), de paredes delgadas, lisas (figura $5 \mathrm{M}$ ) o verrucosas (figuras $5 \mathrm{E}$, 7 G, 23 L).

Unicelulares cilíndricos: Rígidos, cortos, rectos, con la base más o menos redondeada, de paredes delgadas y lisas (figura $23 \mathrm{~T}$ ).

Unicelulares laminares: Flexibles, algo elongados, dispuestos paralelos a la superficie epidérmica, de paredes delgadas y lisas (figura $3 \mathrm{H}$ ).

Unicelulares filiformes: Flexibles, unas 10 veces más largos que anchos, ligeramente curvados, de paredes delgadas y lisas en la mitad superior y barbada en la base del pelo (figura $5 \mathrm{~N}$ ).

Unicelulares uncinados: Rígidos, cortos, curvos en el ápice, con la base ensanchada, de paredes lisas (figura $10 \mathrm{C}$ ).

Unicelulares acintados: Flexibles y chatos (sección rectangular), largos, rectos o curvos, con la base 
Tabla 1. Lista de taxones estudiados.

Table 1. List of taxa studied.

\begin{tabular}{|c|c|}
\hline TAXONES & EXSSICATA \\
\hline $\begin{array}{l}\text { ANEMIACEAE } \\
\text { Anemia australis (Mickel) M. Kessler \& A.R. Sm. }\end{array}$ & Luján 106; Luján 118 \\
\hline Anemia tomentosa (Savigny) Sw. var. tomentosa & Cantero et al. s.n. (RIOC2123) \\
\hline Anemia tomentosa var. anthriscifolia (Schrad.) Mickel & Ariza Espinar 1402 \\
\hline $\begin{array}{l}\text { ASPLENIACEAE } \\
\text { Asplenium monanthes L. }\end{array}$ & Morero 84; Cantero et al. s.n. (RIOC2190) \\
\hline $\begin{array}{l}\text { BLECHNACEAE } \\
\text { Blechnum cordatum (Desv.) Hieron. }\end{array}$ & Morero 161; Subils 1761 \\
\hline Blechnum hastatum Kaulf. & Morero 143; Morero 43 \\
\hline $\begin{array}{l}\text { DRYOPTERIDACEAE } \\
\text { Elaphoglossum gayanum (Fée) T. Moore }\end{array}$ & Barboza 783; Morero 24 \\
\hline $\begin{array}{l}\text { EQUISETACEAE } \\
\text { Equisetum bogotense Kunth }\end{array}$ & Zavala 3894 (RCV) \\
\hline Equisetum giganteum $\mathrm{L}$. & Luján 40; Luján 72 \\
\hline $\begin{array}{l}\text { LOMARIOPSIDACEAE } \\
\text { Nephrolepis cordifolia (L.) C. Presl }\end{array}$ & Luján 107; Luján 119 \\
\hline $\begin{array}{l}\text { LYCOPODIACEAE } \\
\text { Huperzia saururus (Lam.) Trevis. }\end{array}$ & Luján 73; Luján 120 \\
\hline Lycopodium clavatum $\mathrm{L}$. & Morero 89; Morero 152 \\
\hline Lycopodium thyoides Humb. \& Bonpl. ex Willd. & Morero 150; Ariza Espinar 3070 \\
\hline $\begin{array}{l}\text { POLYPODIACEAE } \\
\quad \text { Pleopeltis pinnatifida Gillies ex Hook. \& Grev. }\end{array}$ & Morero 133; Morero 25 \\
\hline Serpocaulon gilliesii (C. Chr.) A. R. Sm. & Morero 273; Morero 3 \\
\hline $\begin{array}{l}\text { PTERIDACEAE } \\
\text { Adiantopsis chlorophylla (Sw.) Fée }\end{array}$ & Morero 34; Morero 41 \\
\hline Adiantum orbignyanum Mett. ex Kuhn & Morero 83; Morero 162 \\
\hline Adiantum raddianum C. Presl & Morero 51; Morero 125 \\
\hline Adiantum thalictroides Willd. ex Schltdl. var. thalictroides & Morero 286; Morero 175 \\
\hline $\begin{array}{l}\text { Adiantum thalictroides var. hirsutum (Hook. \& Grev.) } \\
\text { de la Sota }\end{array}$ & Hunziker 8805; Cantero et al. s.n. (RIOC2294) \\
\hline Argyrochosma nivea (Poir.) Windham var. nivea & Morero 11; Morero 68 \\
\hline Argyrochosma nivea var. flava (Hook.) Ponce & Morero 227; Luján 111 \\
\hline Cheilanthes marginata Kunth & Morero 151; Morero 166 \\
\hline Cheilanthes myriophylla Desv. & Luján 108; Luján 115 \\
\hline Cheilanthes obducta Mett. ex Kuhn & Morero 59; Morero 97 \\
\hline $\begin{array}{l}\text { SALVINIACEAE } \\
\text { Azolla cristata Kaulf. }\end{array}$ & Di Fulvio 520; Hunziker 10348 \\
\hline Azolla filiculoides Lam. & Morero 287; Di Fulvio 466 \\
\hline $\begin{array}{l}\text { WOODSIACEAE } \\
\text { Cystopteris fragilis (L.) Bernh. }\end{array}$ & Morero 172; Morero 234 \\
\hline
\end{tabular}


ensanchada, de paredes delgadas. Pueden tener el ápice redondeado (figuras $4 \mathrm{~J}, 7 \mathrm{~J}$ ) o atenuado (figura $5 \mathrm{O}$ ). Los pelos absorbentes radicales de la mayoría de las especies tratadas son similares a los pelos acintados.

Papilas: Flexibles, cortas, en forma de dedo de guante o triangulares, de paredes delgadas y lisas (figuras $5 \mathrm{~K}$, 24 I, J); por excepción, bicelulares.

Pluricelulares cónicos: Con 4-10 células, de paredes lisas o verrucosas; la célula distal larga, angosta y con ápice agudo, las proximales rectangulares y casi de igual tamaño (figuras $9 \mathrm{G}, 19 \mathrm{H}$ ).

Pluricelulares cilíndricos: Con 5-10 células de paredes lisas; las células distales estrechas, las basales rectangulares o isodiamétricas, de igual longitud que las distales o más cortas (figuras 5 J, 15 G, 19 I). En las distales, puede haber indicios de ramificación (figura $5 \mathrm{~J}$ ).

Pluricelulares filiformes: Con 9-12 células, de paredes lisas; la célula distal muy corta y ápice agudo, las proximales largamente rectangulares (figuras $4 \mathrm{~L}$, $19 \mathrm{M})$.

Pluricelulares estrellados: Varían sustancialmente en tamaño y número de células. Pueden ser sésiles o pedicelados; con 9-15 ramas unicelulares, muy largas y flexuosas (figuras 22 F, 27 B), o con sólo 5-6 ramas muy cortas y rígidas (figura $23 \mathrm{~S}$ ). Son muy raros.

Pluricelulares dendroides: Las 9-12 ramificaciones largas, cónicas y de paredes lisas nacen sobre un eje más o menos articulado, distribuyéndose en distintos planos (figuras $8 \mathrm{D}, 16 \mathrm{I}, 27 \mathrm{~A}, 27 \mathrm{C}$ ).

Pluricelulares ramificados cónicos: Son largos, con varias ramificaciones cortas y cónicas o algo redondeadas (figura $19 \mathrm{E}$ ), de paredes lisas; las ramificaciones pueden ser distales (figura $19 \mathrm{G}$ ), proximales (figura $23 \mathrm{~N}$ ) o desarrollarse a lo largo de todo el pelo (figura $5 \mathrm{~F}$ ).

Pluricelulares ramificados acintados: Largamente flexuosos, aplanados y generalmente estriados, sostenidos por un pie corto bien desarrollado (figura $23 \mathrm{P}, \mathrm{Q}$ ). Las extensas ramificaciones pueden ser desde laminares a filamentosas, de longitud variable.

Pelos glandulares - Con un solo tipo unicelular; el resto son pluricelulares (capitados o no) y la mayoría de pared lisa. Se reconocen las siguientes variantes: Estipitados unicelulares globosos: La región apical globosa se prolonga en un cuello o estípite, con contenido denso y pared celular muy gruesa (figura $25 \mathrm{D}$ ).

Pluricelulares, cabeza unicelular cilíndrica: Con dos o más células del pie, todas cortas (figura $23 \mathrm{G}, \mathrm{I}$ ) o largas (figuras $4 \mathrm{H}, 22 \mathrm{~N}, \mathrm{O}$ ); cuando el pie es unicelular, éste puede ser de igual o un poco más largo que la cabezuela (figuras 15 E, 19 H, 25 G, 27 D, I, J). Algunos pelos tienen la célula subapical también secretora (figura $6 \mathrm{H}, \mathrm{Q}$ ).

Pluricelulares, cabeza unicelular elipsoidal: Según la característica de la célula glandular, se reconocen dos subtipos:

Con cabeza muy dilatada (figuras $4 \mathrm{I}, 5 \mathrm{P}, \mathrm{Q}$, 6 Q). En Anemia australis es notable la variación de la forma del pelo según su estado de desarrollo; cuando joven, las células del pie son poco alargadas (figura $3 \mathrm{~F}$ ) mientras que la cabezuela se dilata a la vez que se elonga (figura $3 \mathrm{C}, \mathrm{D}$ ). Cuando los pelos son adultos, las células distales del pie se alargan y sus paredes se pigmentan sustancialmente (figura $3 \mathrm{M}$ ), pudiendo perder la cabezuela.

Con cabeza muy estrecha (figura $4 \mathrm{~K}, 19 \mathrm{~F}$ ). Este subtipo tiene varias células basales del pie muy cortas y una muy larga hasta contactarse con la cabezuela. Pluricelulares, cabeza unicelular globosa estipitada: Pueden ser cortos (figuras $3 \mathrm{~K}, 15 \mathrm{~K}$ ) o largos (figura 19 L), dependiendo de la longitud del pie. La célula globosa secretora se prolonga angostamente hacia basal formando el estípite de longitud variable (figuras $3 \mathrm{~K}, 6 \mathrm{C}, \mathrm{G}, \mathrm{I}, \mathrm{N}, \mathrm{P}, 15 \mathrm{I}, \mathrm{K}, \mathrm{L}, \mathrm{O}, 17 \mathrm{C}, \mathrm{E}, \mathrm{F}$, $19 \mathrm{~J}, \mathrm{~L}, 25 \mathrm{D})$.

Pluricelulares, cabeza unicelular globosa, suborbicular o elongada no estipitada. Con número de células y longitud del pie variables; las células son rectangulares y algunas con contenido denso. El pie es 1-5-celular, igual o más largo que la cabezuela (figuras $14 \mathrm{E}, 15 \mathrm{E}$, $16 \mathrm{C}, 20 \mathrm{C}, 23 \mathrm{~K}$ ). Algunos pelos muestran en el cuerpo tricomático, indicio de ramificación (figura $25 \mathrm{C}$ ). Los pelos con pie muy corto o sin pie, por logeneral tienen cabezuela glandular muy conspicua (figura $3 \mathrm{~L}, 20 \mathrm{H}$, $\mathrm{K}, 22 \mathrm{C}$ ). Otros pelos con igual cabezuela, pueden ser sésiles, por lo que se asienta sobre una célula basal algo elevada (figura $3 \mathrm{G}$ ). Algunos pelos marginales de escamas tienen la célula del pie a veces glandular (figura $14 \mathrm{H}$ ).

Pluricelulares, cabeza unicelular claviforme o doliiforme: Pie largo bicelular, de paredes más o menos sinuosas (figura $21 \mathrm{~B}, \mathrm{E}$ ); la cabeza algo o muy elongada (figura $27 \mathrm{~K}$ ).

Pluricelulares bifurcados con cabeza unicelular cilíndrica: La bifurcación ocurre por encima de una única célula del pie (figura 15 F, 27 E); a veces se han hallado más de dos cabezuelas.

Pluricelulares ramificados con cabeza unicelular elongada o subglobosa: Se ramifican en tres o más 
ramas desiguales y verrucosas en la base del pelo, asentándose, a veces, sobre un corto pedicelo (figura $10 \mathrm{D}, 27 \mathrm{G})$.

Pluricelulares, cabeza pluricelular peltada: El pie puede tener células más o menos isodiamétricas (figura $4 \mathrm{C}$ ) o las células epibasales son altas y las basales cortas (figura $4 \mathrm{M}$ ); cabeza subglobosa.

Pluricelulares, no capitados: Con 2 a 3 células basales y una única célula secretora apical muy larga (figura $6 \mathrm{~F}$ ).

Pelos de aspecto escamoso - Se define aquí pelos de aspecto escamoso, aquéllos simples o ramificados con célula apical globosa; la pared celular está diferencialmente engrosada, pigmentada y lignificada siendo de aspecto similar a las escamas. Se reconocen 2 tipos:

Pelos catenulados: Son uniseriados; la célula distal con contenido denso y las del pie dilatadas y otras muy colapsadas (figura 10 E, F, 16 E). En ciertas especies, las células tienen algunas paredes ahorquilladas (figura $22 \mathrm{G}$ ).

Pelos ramificados: Con ramificaciones en número variable por encima de las células basales (algunas biseriadas), con paredes adyacentes engrosadas y pigmentadas de amarillo (figura 25 I).

Estructuras de ventilación - Se observaron diversos tipos cuya función es el intercambio gaseoso. Se distinguen en cámaras externas respiratorias, poros de ventilación, lenticelas y estomas.

Las cámaras externas respiratorias se originan cuando los estomas se encuentran muy hundidos generando un espacio externo que puede estar cubierto por restos de sílice. Es el caso de las especies de Equisetum analizadas (figura $9 \mathrm{E}$ ).

Los poros de ventilación se generan cuando se lisan las células oclusivas de un estoma dejando en evidencia un poro. Se observó en Lycopodium clavatum (figura $12 \mathrm{~B}$ ).

Las lenticelas son pequeñas áreas ovales oscuras, de parénquima laxo desprovisto de epidermis, la que originalmente poseía una elevada densidad de estomas. Son característicos de Blechnum cordatum (figura $5 \mathrm{D}$ ).

Los estomas son muy variados. Se encontraron estomas anomocíticos, actinocíticos, anisocíticos, copolocíticos, desmocíticos, diacíticos, estaurocíticos, hemiparacíticos, paracítico-criptoporos, pericíticos, polocíticos y tetracíticos. Los estomas más frecuentes son los anomocíticos y polocíticos, siendo los actinocíticos, anisocíticos, estaurocíticos y paracíticos los menos comunes (tabla 2). Los estomas más particulares son los paracítico-criptoros de Equisetum y los distintos tipos (pericíticos y desmocíticos) de Anemia. Respecto a los primeros, las células oclusivas están hundidas y parcialmente cubiertas por las subsidiarias laterales; las células oclusivas poseen además finas estrías y cristales de sílice en sus paredes (figura 9 F). En cuanto a los estomas de Anemia (figura $3 \mathrm{~B}$ ), en los pericíticos, las células oclusivas están suspendidas dentro de una célula subsidiaria (también llamados "estomas libres" o "flotantes", según Mickel \& Lersten 1967) y en los desmocíticos, las células oclusivas están sostenidas dentro de una subsidiaria por un "cordón" que resulta de la extensión de la pared (=“estomas suspensa”, según Prantl 1881).

Los estomas se disponen a nivel de la epidermis (p.e. Pleopeltis pinnatifida, figura $14 \mathrm{G}$ ), elevados sobre ésta (Cheilanthes obducta, figura $23 \mathrm{~K}$; Anemia australis, figura $3 \mathrm{~J}$ ), o hundidos (Adiantum raddianum, figura $18 \mathrm{D}$ ). La epidermis caulinar generalmente no presenta estomas; éstos aparecen en raquis y pecíolos (Cystopteris fragilis, Pleopeltis pinnatifida), o solamente en raquis (Serpocaulon gilliesii, las tres especies de Cheilanthes, Asplenium monanthes, Blechnum cordatum, Anemia tomentosa), o limitados a las expansiones alares del raquis (Adiantopsis chlorophylla). En hojas, se distribuyen en la superficie inferior de la lámina en la mayoría de las especies tratadas y escasamente en ambas superficies (Azolla spp., Lycopodium spp., Huperzia saururus y Cystopteris fragilis).

Descripción de la epidermis de cada órgano por especie

Familia Anemiaceae

1. Anemia australis (Mickel) M. Kessler \& A. R. Sm. Figura 3

Lámina del trofofilo y esporofilo - Epidermis unistrata; cutícula gruesa y algo estriada sobre los nervios. Epifilo e hipofilo con células isodiamétricas que contienen cloroplastos y cristales prismáticos; paredes gruesas y sinuosas; sobre los nervios son largamente rectangulares y escasamente sinuosas. Células epidérmicas alternando con fibras cuya pared tangencial externa, en algunos casos, protruye hacia el exterior conformando una estructura llamada estegmata. Lámina hipostomática. Estomas ligeramente elevados a muy elevados, anomocíticos, desmocíticos, diacíticos, hipocíticos, pericíticos y 
Tabla 2. Tipos de estomas de helechos y licófitas medicinales de la Provincia de Córdoba, Argentina.

Table 2. Types of stomata of medicinal ferns and licophytes from Córdoba Province, Argentina.

\begin{tabular}{|c|c|c|c|c|c|c|c|c|c|c|c|c|c|}
\hline ESTOMAS & 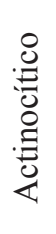 & 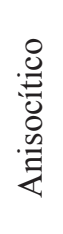 & 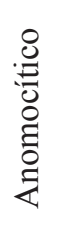 & 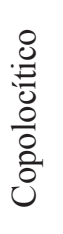 & 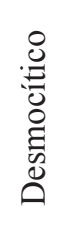 & 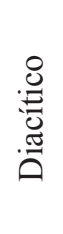 & 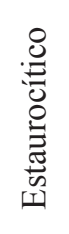 & 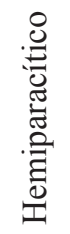 & 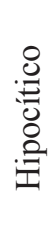 & 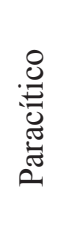 & : & $\begin{array}{l}\stackrel{0}{0} \\
: 0 \\
0 \\
0 \\
0\end{array}$ & 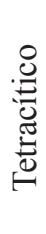 \\
\hline $\begin{array}{l}\text { ANEMIACEAE } \\
\text { Anemia australis }\end{array}$ & & & $\mathrm{x}$ & & $x$ & $\mathrm{x}$ & & & $\mathrm{x}$ & & $\mathrm{x}$ & $\mathrm{x}$ & \\
\hline A. tomentosa var. anthriscifolia & & & $\mathrm{x}$ & & $\mathrm{x}$ & $\mathrm{x}$ & & & $\mathrm{x}$ & & $\mathrm{x}$ & $\mathrm{x}$ & \\
\hline A. tomentosa var. tomentosa & & & $\mathrm{x}$ & & $\mathrm{x}$ & $\mathrm{x}$ & & & $\mathrm{x}$ & & $\mathrm{x}$ & $\mathrm{x}$ & \\
\hline $\begin{array}{l}\text { ASPLENIACEAE } \\
\text { Asplenium monanthes }\end{array}$ & & & $\mathrm{x}$ & $\mathrm{x}$ & & $\mathrm{x}$ & & & & & & $\mathrm{x}$ & \\
\hline $\begin{array}{l}\text { BLECHNACEAE } \\
\text { Blechnum cordatum }\end{array}$ & & & $\mathrm{x}$ & $\mathrm{x}$ & & & & & & & & $\mathrm{x}$ & \\
\hline B. hastatum & & & $\mathrm{x}$ & $\mathrm{x}$ & & & & & & & & $\mathrm{x}$ & \\
\hline $\begin{array}{l}\text { DRYOPTERIDACEAE } \\
\text { Elaphoglossum gayanum }\end{array}$ & & & $\mathrm{x}$ & $\mathrm{x}$ & & $\mathrm{x}$ & & $\mathrm{x}$ & & & & $\mathrm{x}$ & \\
\hline $\begin{array}{l}\text { EQUISETACEAE } \\
\text { Equisetum bogotense }\end{array}$ & & & & & & & & & & $\mathrm{X}$ & & & \\
\hline E. giganteum & & & & & & & & & & $\mathrm{x}$ & & & \\
\hline $\begin{array}{l}\text { LOMARIOPSIDACEAE } \\
\text { Nephrolepis cordifolia }\end{array}$ & & $\mathrm{x}$ & $\mathrm{x}$ & $\mathrm{x}$ & & $\mathrm{x}$ & $\mathrm{x}$ & & & & & $\mathrm{x}$ & $\mathrm{x}$ \\
\hline $\begin{array}{l}\text { LYCOPODIACEAE } \\
\text { Huperzia saururus }\end{array}$ & & & $x$ & & & & & & & & & & \\
\hline Lycopodium clavatum & & & $\mathrm{x}$ & & & & & & & & & & \\
\hline L. thyoides & & & $\mathrm{x}$ & & & & & & & & & & \\
\hline $\begin{array}{l}\text { POLYPODIACEAE } \\
\text { Pleopeltis pinnatifida }\end{array}$ & & & $\mathrm{x}$ & & & & & & & & & $\mathrm{x}$ & $\mathrm{x}$ \\
\hline Serpocaulon gilliesii & & & $x$ & $\mathrm{x}$ & & & & & & & & $x$ & \\
\hline $\begin{array}{l}\text { PTERIDACEAE } \\
\text { Adiantopsis chlorophylla }\end{array}$ & & & $\mathrm{x}$ & & & $\mathrm{x}$ & & & & & & $\mathrm{x}$ & $\mathrm{x}$ \\
\hline Adiantum orbignyanum & & & $\mathrm{x}$ & & & $\mathrm{x}$ & & & & & & $\mathrm{x}$ & \\
\hline A. raddianum & & & $\mathrm{x}$ & & & $\mathrm{x}$ & & & & & & $\mathrm{x}$ & \\
\hline A. thalictroides var. thalictroides & & & $\mathrm{x}$ & & & $\mathrm{x}$ & & & & & & $\mathrm{x}$ & \\
\hline A. thalictroides var. hirsutum & & & $\mathrm{x}$ & & & $\mathrm{x}$ & & & & & & $\mathrm{x}$ & \\
\hline Argyrochosma nivea var. nivea & $\mathrm{x}$ & & $\mathrm{x}$ & & & & & & & & & $\mathrm{x}$ & $\mathrm{x}$ \\
\hline A. nivea var. flava & $\mathrm{x}$ & & $\mathrm{x}$ & & & & & & & & & $\mathrm{x}$ & $\mathrm{x}$ \\
\hline Cheilanthes marginata & & & $\mathrm{x}$ & & & & & & & & & $x$ & \\
\hline C. myriophylla & & & $\mathrm{X}$ & & & & & & & & & $\mathrm{x}$ & \\
\hline C. obducta & & & $\mathrm{x}$ & & & & & & & & & $\mathrm{x}$ & \\
\hline $\begin{array}{r}\text { SALVINIACEAE } \\
\text { Azolla cristata }\end{array}$ & & & $\mathrm{x}$ & & & & & & & & & & \\
\hline A. filiculoides & & & $\mathrm{x}$ & & & & & & & & & & \\
\hline $\begin{array}{l}\text { WOODSIACEAE } \\
\text { Cystopteris fragilis }\end{array}$ & & & $\mathrm{x}$ & $\mathrm{x}$ & & $\mathrm{x}$ & & & & & & $\mathrm{x}$ & $\mathrm{x}$ \\
\hline
\end{tabular}


polocíticos. Indumento: ambas epidermis con pelos eglandulares unicelulares laminares y glandulares pluricelulares, con cabeza unicelular elipsoidal muy dilatada o muy estrecha (según su estado de desarrollo) o con cabeza globosa estipitada o cabeza elongada no estipitada, este último con un pie muy breve o sésil. Escamas ausentes.

Indusio - Ausente

Raquis - Epidermis unistrata; cutícula gruesa y lisa; células isodiamétricas con paredes sinuosas. Aislados estomas desmocíticos. Comparten iguales pelos que la lámina.

Pecíolo - Epidermis unistrata, lignificada con paredes rectas. Surco medio con estegmatas. Estomas ausentes; poros de ventilación bien desarrollados. Iguales pelos que los de la lámina, excepto el tipo glandular con cabeza unicelular elongada no estipitada

Rizoma - Epidermis unistrata. Las células son subrectangulares, de paredes rectas y lignificadas. Sin estomas. Pelos muy largos y rojizos, glandulares pluricelulares con cabeza unicelular elipsoidal muy dilatada o muy estrecha.

\section{Anemia tomentosa (Savigny) Sw.}

Figura $28 \mathrm{C}$

Anemia tomentosa var. tomentosa y Anemia tomentosa var. anthriscifolia (Schrad.) Mickel, en general, son más pubescentes que Anemia australis. Solo en A. tomentosa var. anthriscifolia hay mayor densidad de estomas pericíticos y desmocíticos y no presenta estomas diacíticos.

Familia Aspleniaceae

\section{Asplenium monanthes L.}

Figuras 1, 4

Lámina - Epidermis unistrata; cutícula delgada y lisa. Epifilo e hipofilo con células isodiamétricas de paredes delgadas y sinuosas, o curvas y algo rectas sobre los nervios y hacia los márgenes; contenido celular con cristales prismáticos, drusas y areniscas cristalinas. Lámina hipostomática; estomas a nivel, mayormente polocíticos y copolocíticos, algunos anomocíticos y diacíticos. Indumento: epifilo glabrescente con escasos pelos glandulares cilíndricos (cabeza 1-celular obtusa muy dilatada, pie 2-3-celular). Hipofilo pubescente con pelos similares a los del epifilo y pelos eglandulares unicelulares acintados y cónicos. Entre los esporangios hay pelos eglandulares uniseriados filiformes. Escamas filiformes solo en el hipofilo, de longitud variable, margen hialino algo irregular, las células de la mitad superior con paredes lignificadas. Indusio - Elíptico, con margen irregular. Células de forma variada, con paredes y cutícula delgada; en la zona central son isodiamétricas de paredes sinuosas y con abundantes gránulos de almidón; otras alargadas radialmente con paredes curvas. Pelos glandulares con cabeza peltada y pie pluricelulares, unos con pie largo, otros con pie corto en el borde del indusio.

Raquis - Epidermis unistrata; cutícula fina, ligeramente estriada; células isodiamétricas con pared tangencial externa muy gruesa y las radiales delgadas. Estomas ausentes. Pelos y escamas similares al hipofilo, salvo los pelos glandulares cilíndricos que están ausentes. Pecíolo - Epidermis similar a la del raquis; también presentes pelos glandulares pluricelulares flexuosos con 2-3 células proximales cortas, seguidas de una larga célula y la distal elipsoidal estrecha y pigmentada. Escamas basifijas clatradas, unas largamente filiformes y otras triangulares, ambas terminadas en una célula globosa en la base del pecíolo, algunas escamas con márgenes ligeramente denticulados.

Rizoma - Epidermis unistrata, con células subcuadradas de paredes delgadas y lignificadas. Estomas ausentes. Pelos y escamas similares a los del pecíolo.

Familia Blechnaceae

\section{Blechnum cordatum (Desv.) Hieron.}

Figuras 1, 5, 26 A, H, $28 \mathrm{H}$, I

Lámina - Epidermis uni-biestratificada; cutícula delgada, estriada la superior y lisa la inferior. Epifilo e hipofilo con células isodiamétricas de paredes gruesas y sinuosas, o de curvas a rectas sobre los nervios y hacia los márgenes; contienen cristales prismáticos. En ocasiones la epidermis unistrata está interrumpida por un estrato 2-3-celular. En leves depresiones de la epidermis inferior, donde las células son más pequeñas, subcuadradas y de paredes rectas, se ubican los hidatodos, coincidentes internamente con un epitema. Lámina hipostomática; estomas a nivel, generalmente alineados regularmente y concentrados en la zona media de la lámina, la mayoría polocíticos y copolocíticos, otros anomocíticos. Indumento: epifilo glabrescente. Pelos variados pero muy aislados, eglandular unicelular cónico verrucoso y acintados, también glandulares pluricelulares con cabezuela unicelular muy dilatada. Hipofilo pubescente, con similares pelos que el epifilo, además pelos eglandulares pluricelulares ramificados, con ramificaciones cortas y cónicas. Escamas limitadas al hipofilo; la mayoría son microescamas, muy irregulares, algunas con márgenes 
laciniados, sub-basifijas o bien aparentan fijarse al órgano por alguna de las extensiones del margen; en menor proporción se encuentran escamas aovado deltoideas, con márgenes irregulares hasta laciniados con una célula terminal globosa e inserción sub-basal. Indusio - Lineal con margen fimbriado-lacerado. Células alargadas, con paredes curvas; cutícula delgada.

Raquis - Epidermis unistrata y ligeramente pubescente. En transcorte, la cutícula es delgada, lisa y con corpúsculos grasos. Células isodiamétricas, algunas algo lageniformes. Estomas por lo general polocíticos y copolocíticos. Iguales pelos eglandulares, microescamas y escamas que el hipofilo.

Pecíolo - Epidermis uni-biestratificada, lignificada, muy papilosa en el surco medio del pecíolo; cutícula gruesa y lisa. Células subrectangulares, con paredes de rectas a curvas, gruesas y con notables puntuaciones. Se destacan líneas de ventilación y lenticelas en tres etapas de maduración. Además de papilas, con iguales pelos que el hipofilo y raquis. En la base del pecíolo, con escamas basifijas, aovado-lanceoladas a aovado-triangulares, castañas y de margen entero y otras con prolongaciones marginales y sub-basifijas. Cuando jóvenes, todas las escamas terminan en una célula globosa.

Rizoma - Epidermis unistrata y escamosa; células subcuadradas de paredes curvas, delgadas y lignificadas. Estomas ausentes. Pelos eglandulares unicelulares filiformes con margen barbado. Escamas muy desarrolladas, similares a las de la base del pecíolo, pero por lo general, con margen entero.

\section{Blechnum hastatum Kaulf.}

Figuras 1, 6, 27 F, H, 28 E, K, L

Lámina - Epidermis unistrata; cutícula delgada y lisa. Epifilo con células alargadas, algunas isodiamétricas, con sinuosidades frecuentes e irregulares; células del margen con dentículos cónicos curvos o rectos. Hipofilo con células alargadas o isodiamétricas mayores que las del epifilo y con sinuosidades más amplias y regulares. Lámina hipostomática; estomas polocíticos, copolocíticos y anomocíticos. Hipofilo pubescente. Indumento: pelos pluricelulares glandulares con cabeza globosa estipitada o pelos con cabeza elipsoidal dilatada y célula del pie que se estrecha hacia la base, ambos con contenido, muy frecuentes y asociados a los nervios. Pelos glandulares pluricelulares no capitados o con cabezuela cilíndrica más escasos. Hipofilo con microescamas lineares a triangulares, bicolores, margen liso o con ramificaciones laterales que finalizan en una célula glandular.
Indusio - Linear con margen papiloso. Sobre la superficie y el borde, pelos glandulares con cabezuela dilatada estipitada y pie 1-celular.

Raquis y pecíolo - Epidermis unistrata; cutícula delgada y lisa. Células alargadas de paredes rectas, coronadas por una papila redondeada de paredes engrosadas. Estomas ausentes. Pelos glandulares pluricelulares frecuentes, similares a los de la lámina; también son comunes los pelos glandulares con cuerpo 1-celular y cabezuela apenas diferenciada. Escamas basifijas, angostamente triangulares u ovadas, márgenes con pelos de pie 1-2-celular y cabezuela globosa o cilíndrica y algunas prolongaciones terminadas en una célula glandular.

Rizoma - Epidermis unistrata. En transcorte, células cuadrangulares, de paredes engrosadas y lignificadas. Escamas basifijas, ovado-lanceoladas, a veces esclerosadas a todo lo largo o sólo en la porción basal, escasas prolongaciones marginales que terminan en una célula glandular y algunos pelos marginales.

Familia Dryopteridaceae

\section{Elaphoglossum gayanum (Feé) T. Moore}

Figuras 1, 7, 26 B

Lámina del trofofilo y esporofilo - Epidermis uni-biestratificada; cutícula gruesa, lisa y con corpúsculos grasos. Epifilo con células poligonales de pared gruesa, muy sinuosa y laminilla media recta. En ligeras depresiones de la epidermis, hidatodos que coinciden, hacia el mesofilo, con un epitema irrigado por traqueidas. Hipofilo de células isodiamétricas con pared gruesa y sinuosa, la laminilla media acompaña estas sinuosidades. Lámina hipostomática; estomas a nivel, distribuidos uniformemente, del tipo polocíticos, copolocíticos y diacíticos, también anomocíticos y hemiparacíticos, todos con abundantes cloroplastos. Indumento: escasos pelos y escamas bien representadas. Pelos eglandulares unicelulares cónicos verrucosos y acintados. Escamas peltadas con células de paredes engrosadas en la zona de inserción, algunas de forma irregular y otras lanceoladas con ramificaciones marginales y ápice globoso. Hipofilo con frecuentes microescamas pediceladas aracniformes.

Indusio - Ausente

Pecíolo - Epidermis similar a la de la lámina. En vista superficial, las células son subrectangulares con paredes gruesas, rectas y notables puntuaciones, citoplasma con abundantes gránulos de almidón y areniscas cristalinas. Entre las células epidérmicas 
alternan agrupaciones de fibras e idioblastos pigmentados. Sin estomas. Iguales pelos y escamas que la lámina.

Rizoma - Epidermis unistrata y muy escamosa; células cuadrangulares con pared delgada y recta. Sin estomas. Escamas deltoide-lanceoladas a lanceoladas con ramificaciones marginales y ápice globoso.

Familia Equisetaceae

\section{Equisetum bogotense Kunth}

Figuras 8, $27 \mathrm{~A}$

Vaina foliar (en tallo aéreo y subterráneo) - Epidermis glabra, hipostomática (la extensión denticular de la vaina es anfistomática). Epifilo unistrato; células isodiamétricas con paredes gruesas y silicificadas; cutícula delgada y ligeramente estriada. En vista superficial, la pared celular es muy sinuosa en la zona carinal, algo sinuosa en la zona valecular y curva en los extremos foliares. Hipofilo uni-(bi)-estratificado. Características celulares similares a las del epifilo. Algunos estratos epidérmicos del hipofilo se interrumpen por un grupo de células conspicuas $\mathrm{y}$ alargadas en forma de herradura; las mismas conforman el seno comisural (unión entre dos hojas). La comisura se extiende por el mesofilo, hasta antes del epifilo. Estomas paracítico-criptoporos, a nivel o algo hundidos, ubicados en la zona valecular. Los estomas foliares tienen igual particularidad que los caulinares; en las vainas rizomáticas son muy raros. Tallo aéreo - Epidermis bi-(tri)-estratificada, glabrescente, con depósito de sílice, muy estriada.

Células isodiamétricas, pared celular muy gruesa y sinuosa; cutícula delgada. Estomas paracítico-criptoporos, algo elevados, otros a nivel y más o menos alineados en los surcos. Escasos pelos eglandulares pluricelulares ramificados dendroides.

Rizoma - Epidermis uni-bi-(tri)-estratificada, glabra, con escasos corpúsculos de súlice. Sin estomas, con líneas de ventilación profundas. Células isodiamétricas, pared celular más delgada y menos sinuosa que las del tallo aéreo.

\section{Equisetum giganteum L.}

Figuras 9, $28 \mathrm{~F}$

Vaina foliar (en tallo aéreo y subterráneo) - Muy similar a $E$. bogotense. Se diferencia por la cutícula que es lisa, el hipofilo es pluriestratificado y los estomas paracítico-criptoporos en las vainas rizomáticas son mas abundantes.
Tallo aéreo y subterráneo - Son histológicamente muy semejantes. A diferencia de E. bogotense, esta especie posee dos estructuras de respiración: a) una cámara externa respiratoria conformada por el espacio que dejan los estomas hundidos, b) estrías neumáticas, cubiertas por un parénquima hialino que le sirve de respiración, c) lenticela generada cuando el parénquima se desprende. Los tallos jóvenes y frescos con pelos eglandulares pluricelulares cónicos con verrugas de sílice, ausentes en rizoma. Los tricomas eglandulares pluricelulares ramificados dendroides están ausentes.

Familia Lomariopsidaceae

\section{Nephrolepis cordifolia (L.) C. Presl}

Figuras 1, 10, 26 C, 27 G, 28 D.

Lámina - Epidermis unistrata; cutícula gruesa, la superior estriada y la inferior lisa. Epifilo e hipofilo con células isodiamétricas y hacia los márgenes y zona limitantes a la vena principal, rectangulares; paredes gruesas y con engrosamientos globosos celulósicos, las del haz son algo sinuosas en tanto las del envés son curvas. Asociadas a estos corpúsculos se observan vesículas lipídicas. Lámina hipostomática. Estomas a nivel, distribuidos uniformemente, anisocíticos, anomocíticos, copolocíticos, diacíticos y estaurocíticos. En ligeras depresiones de la epidermis superior, se encuentran hidatodos secretores de sustancias calcáreas, en esta zona las células son más cortas, las paredes curvas y la cutícula se adelgaza considerablemente. Indumento: epifilo e hipofilo glabrescentes. Ambas epidermis con pelos eglandulares unicelulares uncinados; envés con pelos glandulares ramificados con cabeza unicelular elongada o subglobosa y otros de aspecto escamoso catenulados con célula distal globosa. Escamas ausentes.

Indusio - Reniforme; células isodiamétricas, con paredes gruesas y curvas. Ausencia de estomas, pelos y escamas.

Raquis - Epidermis unistrata; cutícula delgada y lisa; células isodiamétricas con paredes curvas lignificadas. Estomas aislados estaurocíticos y anomocíticos. Escasos pelos eglandulares unicelulares uncinados. Escamas subuladas con margen laciniado en la base. Pecíolo - Epidermis similar a la del raquis pero células con paredes rectas y curvas. Estomas ausentes. Indumento generalmente glabrescente, con pelos: eglandulares unicelulares cilíndricos sinuosos y/o 
flexuosos, glandulares pluricelulares con cabeza unicelular cilíndrica y los de aspecto escamoso (pluricelulares catenulados con célula distal globosa). Rizoma - Epidermis unistrata; células subcuadradas a subrectangulares, de paredes rectas y lignificadas. Pelos glandulares pluricelulares con cabeza unicelular cilíndrica. Escamas muy abundantes, peltadas, sub-basifijas, subuladas, lineares, triangulares y ovado-lanceoladas.

Familia Lycopodiaceae

\section{Huperzia saururus (Lam.) Trevis.}

Figura 11

Lámina del trofofilo y esporofilo - Epidermis unistrata y glabra; cutícula delgada, ligeramente rugosa y con excrescencia supracuticular. Epifilo e hipofilo de células isodiamétricas con núcleos ahusados, pared gruesa y lignificada, sinuosa hacia los márgenes y algo curva hacia la zona media de la lámina. Por lo general, los engrosamientos de la pared celular son discontinuos; laminilla media recta. En transcorte, células de forma navicular, con pared tangencial externa plana, muy gruesa y con extremos globosos, pared tangencial interna convexa y más delgada; hacia los bordes de la lámina, las células son esféricas. Lámina anfistomática; estomas anomocíticos a nivel, con cloroplastos. Indumento ausente.

Indusio - Ausente

Tallo aéreo - Epidermis unistrata y glabra; cutícula muy gruesa, lisa y con excrescencias grasas; células largamente rectangulares, con paredes muy gruesas y curvas a ligeramente sinuosas. Entre las células epidérmicas alternan células lignificadas. Estomas ausentes.

Rizoma - Epidermis similar a la del tallo aéreo pero con mayor cantidad de células lignificadas.

\section{Lycopodium clavatum $\mathrm{L}$.}

Figura 12

Lámina del trofofilo - Epidermis unistrata y glabra; cutícula delgada, lisa y con excrescencias supracuticulares globosas o irregulares. Epifilo e hipofilo con células subrectangulares, pared gruesa, con engrosamientos irregulares que le da un aspecto sinuoso a la célula. Las células epidérmicas propiamente dichas alternan con células lignificadas. Lámina anfistomática; estomas anomocíticos a nivel, todos con cloroplastos.

Lámina del esporofilo - En general, epidermis similar a la del trofofilo, pero las diferencias más notorias son las sinuosidades regulares de la pared celular y la presencia de poros de ventilación. Células del margen alargadas considerablemente acompañando la forma lacerada del mismo. Epidermis del esporangio, fácilmente desprendible, con dos formas celulares según la zona: células de la zona marginal subcuadrangulares con paredes rectas, gruesas y con puntuaciones; células de la zona central, isodiamétricas con paredes sinuosas y engrosamientos celulósicos localizados en crestas y valles. Lámina anfistomática; estomas anomocíticos a nivel, con cloroplastos. Indumento ausente.

Indusio - Ausente

Tallo aéreo erecto y rastrero - Ambos tallos con histología similar. Epidermis unistrata y glabra. Cutícula gruesa, lisa y con excrescencias grasas. Células largamente rectangulares, con paredes muy gruesas y curvas a ligeramente sinuosas. Células epidérmicas alternando con células lignificadas. Estomas anomocíticos solo en la zona carinal del tallo erecto.

Rizoma - Epidermis similar a la del tallo rastrero pero con mayor cantidad de células lignificadas. No se observó cutícula en los rizomas examinados.

12. Lycopodium thyoides Humb. \& Bonpl. ex Willd. Figura 13

Lámina del trofofilo - Epidermis unistrata y glabra; cutícula gruesa, lisa y con excrescencias supracuticulares globosas o irregulares. Epifilo e hipofilo con diversidad de formas celulares, probablemente por el dimorfismo foliar: hojas estériles dimórficas (laterales vs. dorsal y ventral) con disposición tetrásica sobre el tallo erecto; las dos hojas laterales con células irregulares en el epifilo y rectangulares en el hipofilo, la hoja dorsal y ventral con células largamente rectangulares, tanto en la haz como en el envés. La pared celular es gruesa, muy sinuosa y la laminilla media recta. Las células epidérmicas propiamente dichas alternan con células lignificadas. Lámina anfistomática; estomas anomocíticos a nivel y otros elevados, con cloroplastos. Las hojas dorsales y ventrales del tallo erecto comparten características similares a las del tallo rastrero.

Lámina del esporofilo - En general, la epidermis es similar a la del trofofilo. Células con paredes más delgadas y sinuosidades continuas y regulares. Las células alternan con idioblastos lignificados. Estomas anisocíticos a nivel.

Indusio - Ausente

Tallo aéreo erecto y rastrero - Ambos con histología similar. Epidermis unistrata y glabra; cutícula gruesa 
y lisa; células largamente rectangulares, con paredes gruesas y sinuosidades continuas y estrechas. Estomas anomocíticos, solo en el tallo erecto, mientras que el tallo rastrero no presenta este carácter.

Rizoma - Características epidérmicas similares a las del tallo rastrero. No se observó cutícula, al menos en el estado de desarrollo del órgano examinado. Sin estomas.

Familia Polypodiaceae

\section{Pleopeltis pinnatifida Gillies ex Hook. \& Grev.} Figuras 1, 14, 26 D, G, 28 J.

Lámina - Epidermis unistrata; cutícula lisa y delgada. En vista superficial, epifilo con células isodiamétricas o poco alargadas (relación 1,5:1); paredes con sinuosidades regulares curvas o subcuadrangulares; a nivel de los nervios, células alargadas y paredes con ondas más amplias y suaves. Hipofilo con células isodiamétricas y sinuosidades regulares y frecuentes. Lámina hipostomática. Estomas a nivel; anomocíticos, tetracíticos y polocíticos. Indumento con frecuentes pelos glandulares de cabeza globosa, suborbicular o algo elongada, pie 1-2-celular en el hipofilo; muy escasos en epifilo. Escamas clatradas frecuentes en el hipofilo, son peltadas, orbiculares $\mathrm{u}$ ovado-lanceoladas, ápice corto y estrecho, a veces con una célula glandular en el extremo, margen con prolongaciones cortas cónicas, flexuosas, generalmente bicelulares y bífidas.

Raquis y pecíolo - En vista superficial, células alargadas con paredes rectas o algo curvadas; en transcorte, subcuadrangulares a globosas, con paredes engrosadas y pigmentadas; cutícula gruesa y lisa. Expansiones del raquis con estomas anomocíticos. Pelos semejantes a los del hipofilo. Escamas suborbiculares, peltadas, margen con pelos glandulares y prolongaciones bicelulares, cortas y laxas; hacia la base algunas escamas similares a las rizomáticas, aunque con menor grado de esclerosamiento.

Rizoma - En transcorte, células subcuadrangulares, pared tangencial externa convexa, paredes engrosadas y luz celular pequeña. Pelos ausentes. Escamas peltadas, lanceolado-oblongas a ovado-oblongas, bicolores, algunas con una constricción que diferencia la base redondeada del resto de la escama; área media con células de paredes muy esclerosadas y oscuras, extremo glandular y margen con prolongaciones cortas bicelulares, que le dan aspecto eroso.

14. Serpocaulon gilliesii (C. Chr.) A.R. Sm.

Figuras 1, 15, 26 E, 27 D, E, I, J.
Lámina - Epidermis unistrata; cutícula delgada y lisa y, a nivel de la costa, estriada. Epifilo con células alargadas de paredes sinuosas. Hipofilo con células más grandes, alargadas o isodiamétricas, con sinuosidades profundas y amplias. Lámina hipostomática. Estomas a nivel, polocíticos, copolocíticos, anomocíticos y tetracíticos. Hidatodos elípticos hacia el margen del epifilo. Indumento: Epifilo e hipofilo con pelos eglandulares, pluricelulares (3-6-celulares), uniseriados y cilíndricos, la célula basal con paredes engrosadas y lignificadas; muy frecuentes sobre los nervios del hipofilo y los márgenes foliares. En toda la lámina, escasos pelos glandulares pluricelulares, con cabeza globosa estipitada y pie 1-2-celular o bien ramificados con 1-3-cabezuelas elongadas a subglobosas. Limitados al hipofilo, pelos glandulares con cabeza cilíndrica y pie 1-2-celular enangostado hacia la base, con contenido citoplasmático denso. Microescamas triangulares, con paredes celulares anticlinales engrosadas y pigmentadas, en hipofilo. Raquis - Células epidérmicas alargadas, angostas, con paredes rectas. Cutícula lisa y delgada. Estomas copolocíticos y anomocíticos. Pelos glandulares y eglandulares similares a los del epifilo.

Pecíolo - En transcorte, células redondeadas, pared celular engrosada y lignificada. Cutícula lisa y delgada. Líneas respiratorias laterales presentes. En la base, escamas similares a las del rizoma.

Rizoma - Epidermis unistrata; en transcorte, células redondeadas de pared engrosada e impregnada de lignina; este último proceso acentuado en las áreas deprimidas de la epidermis donde se insertan las escamas. Pelos ausentes. Escamas clatradas, peltadas y de coloración uniforme, diferenciándose las células del área central por su mayor tamaño y paredes diferencialmente engrosadas, ovado-lanceoladas, subuladas o lineares, margen irregular con pelos glandulares y pequeños dientecillos romos bicelulares.

Familia Pteridaceae

\section{Adiantopsis chlorophylla (Sw.) Fée}

Figuras 2, 16, $27 \mathrm{C}$

Lámina - Epidermis unistrata; cutícula lisa y delgada. Epifilo e hipofilo con células alargadas, algunas isodiamétricas, de paredes sinuosas y, asociados a éstas, engrosamientos celulósicos irregulares y algo refringentes, contenido celular con vesículas lipídicas, más frecuentes en las células oclusivas. Lámina hipostomática; estomas a nivel, generalmente polocíticos y anomocíticos, menos frecuentemente 
tetracíticos y diacíticos. Indumento: Pelos glandulares pluricelulares con cabeza cilíndrica y pie unicelular enangostado hacia la base, ambos con contenido, más frecuentes en el hipofilo y, limitados a éste, escasos pelos dendroides. Escamas ausentes.

Pseudoindusio - Patrón celular similar al resto de la epidermis foliar, pero con las células del margen papilosas.

Raquis - Células alargadas, angostas, de paredes engrosadas y esclerosadas, con luz celular reducida; cutícula lisa y delgada. Expansiones laterales con células más anchas y de paredes delgadas, no lignificadas y estomas anomocíticos. Pelos glandulares pluricelulares con cabeza dilatada y catenulados con célula distal globosa.

Pecíolo - En transcorte, células isodiamétricas, esclerenquimatosas, con luz reducida; cutícula lisa y delgada. En la base, escamas semejantes a las del rizoma.

Rizoma - Epidermis unistrata, células alargadas en vista superficial y lignificadas. Escamas basifijas, triangular-lanceoladas, bicolores, extremo con célula globosa, margen entero, a veces con algunos dientecillos cónicos incipientes. Área media constituida por células alargadas, angostas, de paredes pigmentadas y esclerosadas; células del margen con paredes delgadas. Formas transicionales de las escamas, con células poliédricas de paredes delgadas, en la porción basal y hacia la mitad superior, células con paredes engrosadas y pigmentadas, rematando en una célula apical globosa secretora.

\section{Adiantum orbignyanum Mett. ex Kuhn}

Figuras 2, 17, $27 \mathrm{~K}$

Lámina - Epidermis unistrata; cutícula lisa y delgada. Epifilo con células 4-8 veces más largas que anchas, paredes con sinuosidades regulares curvas o subcuadrangulares; en transcorte, células de forma globosa. Hipofilo con marcada variación celular en tamaño y forma: células isodiamétricas o alargadas (4-6 veces más largas que anchas); paredes con sinuosidades semejantes al epifilo. Lámina hipostomática. Estomas a nivel; anomocíticos, polocíticos y diacíticos, algunos ligeramente hundidos. En hipofilo y epifilo, pelos glandulares pluricelulares con cabeza unicelular globosa, estipitada, pie 1-2-celular. Escamas ausentes.

Pseudoindusio - Contorno orbicular a reniforme; margen entero. Células epidérmicas isodiamétricas, paredes con sinuosidades amplias y profundas. Pelos glandulares semejantes al resto de la lámina. Raquis - Células epidérmicas alargadas y de paredes rectas. En transcorte, son cuadrangulares, con paredes engrosadas y pigmentadas y luz celular reducida. Cutícula lisa. Estomas ausentes. Pelos glandulares en la zona de articulación con las pínnulas, semejantes a los mencionados para la lámina.

Pecíolo - Modelo epidérmico similar al de los raquis. Algunas escamas en la base, semejantes a las rizomáticas.

Rizoma - Epidermis unistrata, células cuadrangulares con paredes engrosadas y pigmentadas. Estomas ausentes. Pelos ausentes. Escamas pseudoclatradas, basifijas, pediceladas, triangular-lanceoladas, concoloras, castañas, margen entero, ápice agudo no glandular.

\section{Adiantum raddianum C. Presl}

Figuras 2, 18

Lámina - Epidermis unistrata; cutícula delgada y rugosa. Epifilo con células 3 veces más largas que anchas, con paredes sinuosas, excepto a nivel de los nervios y comisuras, donde son rectas; hacia los márgenes, células preferentemente isodiamétricas. Paredes tangenciales internas con lóbulos que se proyectan hacia el mesofilo, denominados proyecciones unguladas, varían en número desde unas pocas hasta 10 o más por célula, están siempre ocupadas por cloroplastos y representan una gran superficie de exposición con los espacios intercelulares del mesofilo. Hipofilo con células de mayor tamaño (4-6 veces más largas que anchas) y sinuosidades más frecuentes; globosas en transcorte. Lámina hipostomática; estomas levemente hundidos, generalmente anomocíticos, además polocíticos y diacíticos.

Pseudoindusio - Contorno orbicular; margen liso. En vista superficial, células epidérmicas poligonales (4-8 lados), isodiamétricas o alargadas, de paredes rectas o levemente curvadas. Glabro.

Raquis y pecíolo - Células alargadas y de paredes rectas; en transcorte, rectangulares de paredes tangenciales convexas, engrosadas y pigmentadas por compuestos fenólicos. Cutícula lisa. Estomas ausentes. En la base del pecíolo, escamas de aspecto similar a las rizomáticas.

Rizoma - En transcorte, células redondeadas, esclerenquimatosas, con luz celular muy reducida. Estomas ausentes. Pelos ausentes. Escamas rizomáticas pseudoclatradas, basifijas, pediceladas, triangular-lanceoladas, concoloras, castañas; margen 
entero y, célula apical alargada con contenido citoplasmático, en los estadios tempranos de la ontogenia.

Observaciones - Las escamas incipientes constan de una sola hilera de células de paredes delgadas; en los estadios siguientes aparecen varias series y la célula apical se alarga, mostrando un contenido denso; el crecimiento ulterior ocurre por multiplicación celular limitada al sector basal de la escama. Escamas jóvenes con entramado de células poligonales, más o menos isodiamétricas, que cambian a formas rectangulares, más angostas y alargadas, en las escamas maduras.

18. Adiantum thalictroides Willd. ex Schltdl. var. thalictroides

Figuras 2, 19 A, B, D, N.

Lámina - Epidermis unistrata; cutícula delgada y superficie irregular. Epifilo con células 3-4 veces más largas que anchas, con paredes sinuosas. Hipofilo con células de formas variadas (las alargadas, con relación largo/ancho 5-6:1) y paredes con sinuosidades muy marcadas e irregulares; en transcorte, las células son voluminosas y con la pared tangencial externa más engrosada. Lámina hipostomática; estomas a nivel, anomocíticos, también polocíticos y diacíticos; con frecuencia estomas contiguos comparten la misma célula acompañante. Indumento ausente.

Pseudoindusio - Predominan con el contorno rectangular o reniforme, menos frecuente el orbicular, los tres en una misma pínnula; margen entero. Células epidérmicas rectangulares o subcuadrangulares, con paredes rectas. Glabro.

Raquis y pecíolo - Epidermis unistrata, esclerenquimatosa; en transcorte, células subcuadrangulares o redondeadas, luz celular muy reducida y paredes pigmentadas. Cutícula lisa. Raquis glabros. Base del pecíolo con escamas similares a las rizomáticas.

Rizoma - Modelo epidérmico similar al de los ejes foliares. Estomas ausentes. Pelos ausentes. Escamas pseudoclatradas, basifijas, pediceladas, triangularlanceoladas, concoloras, castañas, margen provisto de prolongaciones unicelulares largas que le dan aspecto ciliado; extremo alargado, único o ramificado, no glandular.

19. Adiantum thalictroides var. hirsutum (Hook. \& Grev.) de la Sota

Figura 19 C, E, F-M, O-Q.

Presenta células epidérmicas propiamente dichas y células oclusivas más grandes que Adiantum thalictroides var. thalictroides $\mathrm{y}$, en ésta última, las sinuosidades de las paredes son más profundas e irregulares. A diferencia de la variedad típica, el hipofilo de la lámina y los pseudoindusios son pubescentes. Indumento de pelos eglandulares y glandulares, preferentemente sobre los nervios. Pelos eglandulares cónicos, cilíndricos y filiformes o ramificados. Pelos glandulares pluricelulares con cabeza globosa estipitada o elipsoidea.

20. Argyrochosma nivea (Poir.) Windham var. nivea Figuras 2, 20

Lámina - Epidermis unistrata; cutícula lisa y fina. Epifilo e hipofilo con paredes celulares con sinuosidades angulosas; epifilo con células alargadas (algunas isodiamétricas), hipofilo con mayor variedad de formas. Lámina hipostomática; estomas levemente elevados; anomocíticos, polocíticos, tetracíticos y actinocíticos. Hipofilo farináceo. Indumento: pelos glandulares con cabeza unicelular globosa, pie 1-celular, raro 2-celular, secretores de un exudado céreo que otorga al hipofilo color blanquecino y característico aspecto farináceo; son escasos en epifilo. Escamas ausentes.

Pseudoindusio - Margen de la lámina poco modificado, liso y algo revoluto. Células epidérmicas e indumento semejantes a los del resto de la lámina.

Pecíolo y raquis - Células alargadas en vista superficial e isodiamétricas en transcorte, lignificadas, luz reducida y paredes engrosadas. Cutícula lisa. Pelos glandulares semejantes a los descriptos para la lámina. Estomas ausentes.

Rizoma - Epidermis unistrata. Células isodiamétricas en transcorte, esclerenquimatosas. Pelos ausentes. Escamas basifijas, lanceoladas y triangular-lanceoladas, concoloras, ferrugíneas, laxas, de margen entero y con célula terminal globosa glandular.

\section{Argyrochosma nivea var. flava (Hook.) Ponce}

Los caracteres epidérmicos de esta variedad son similares a los de la variedad típica, diferenciándose sólo por la coloración de la farina del hipofilo, que es amarilla en Argyrochosma nivea var. flava y blanca en Argyrochosma nivea var. nivea.

\section{Cheilanthes marginata Kuhn}

Figuras 2, 21, 27 B

Lámina - Epidermis unistrata; cutícula gruesa y lisa. Epifilo con células isodiamétricas y paredes sinuosas. Sobre la superficie foliar del epifilo se diferencian tres zonas según forma celular y presencia o no de 
pelos: zona central completamente glabra y con células largamente subrectangulares; zona marginal algo papilosa; porción reflexa del haz con células irregulares con paredes muy sinuosas. Las dos últimas zonas con aislados pelos glandulares y eglandulares. Hipofilo, similar al epifilo, salvo la superficie epidérmica con uniformidad en la forma celular. Lámina hipostomática, estomas generalmente a nivel, anomocíticos y polocíticos, varios compartiendo iguales células subsidiarias. Indumento: epifilo glabrescente, hipofilo pubescente. Ambas epidermis con pelos eglandulares pluricelulares ramificados acintados y glandulares pluricelular con cabeza unicelular cilíndrica o claviforme.

Pseudoindusio - Margen reflexo del epifilo de consistencia escariosa y borde fimbriado. Células isodiamétricas e irregulares, con contorno sinuoso.

Raquis - Epidermis uni-(bi)-estratificada; cutícula delgada y lisa. Indumento glabrescente. Células de las zonas laterales irregulares, con paredes gruesas y curvas; las de la zona media, isodiamétricas con paredes delgadas y sinuosas. En transcorte, contorno del raquis con profunda escotadura donde las células epidérmicas son de aspecto papiloso; en tanto, en la zona opuesta o entera, células subcuadradas, altas y lignificadas. Estomas en su mayoría anomocítcos y polocíticos, algunos compartiendo una célula subsidiaria, unos pequeños y orbiculares, otros muy largos y elipsoidales; estomas anómalos, con células oclusivas desiguales. Pelos similares a los de la lámina. Pecíolo - Epidermis unistrata; cutícula delgada y lisa. Indumento escamoso. Ausencia de estomas. Células subrectangulares, con paredes gruesas, curvas y lignificadas, con notables núcleos ahusados. En transcorte, algunas células altas y algo lageniformes, otras cortas y cuadradas. Pelos similares a los de la lámina. En la base del pecíolo, en contacto con el rizoma, escamas basifijas ovado-lanceoladas, con margen entero, unas con el extremo globoso y otras apiculado.

Rizoma - Epidermis uniestrata, escamosa y sin estomas. Cutícula muy poco visible. Células subcuadradas, otras rectangulares, con paredes delgadas y rectas. Escamas basifijas, lineares y ovado-lanceoladas a ovadodeltoideas, con margen entero y ápice acuminado o globoso. Pelos unicelulares simples (se encontraron siempre sueltos por lo que, probablemente, sean porciones de los pelos estrellados similares a los presentes en Cheilanthes obducta y Ch. myriophyla).

23. Cheilantes myriophylla Desv.

Figuras 2, 22
Lámina - Epidermis unistrata; cutícula delgada y lisa. Epifilo e hipofilo, con células isodiamétricas y sinuosas. En transcorte, células subrectangulares a subglobosas y pared gruesa. Epidermis hipostomática; estomas a nivel, otros algo elevados, polocíticos y anomocíticos, algunos comparten iguales células subsidiarias. Indumento densamente pubescente. Sobre el epifilo pelos de aspecto escamoso, catenulados con célula distal subcilíndrica, algunas paredes anticlinales ahorquilladas, otras rectas. Escamas lineares, uni-biseriadas con célula distal cilíndrica. Hipofilo con pelos catenulados más largos que los del epifilo, también pelos glandulares con cabeza globosa y pie unicelular muy corto; escamas iguales a las del epifilo. Pseudoindusio - El margen reflexo del epifilo de consistencia escariosa y borde entero, con células isodiamétricas y contorno muy sinuoso. Pelos y escamas aisladas, de igual morfología que las del epifilo.

Raquis - Epidermis unistrata y densamente escamosa; cutícula delgada y lisa. Células subrectangulares con paredes curvas y densas vesículas lipídicas. Estomas y escamas similares a las del epifilo y con otras escamas ovado-deltoideas a ovado-lanceoladas con márgenes enteros.

Pecíolo - Epidermis unistrata, lignificada; cutícula delgada y lisa. Células subrectangulares, con paredes rectas, algunas fibras protruyen entre las células epidérmicas. Sin estomas. Densamente pubescente, pelos glandulares pluricelulares (hasta 10 células), con cabeza cilíndrica unicelular y pelos escamosos catenulados; escamas lineares, ovado-lanceoladas y formas intermedias, algunas con ápice largamente acuminado mientras que, las formas jóvenes llevan célula distal globosa; todas las escamas con márgenes enteros y basifijas.

Rizoma - Epidermis unistrata, lignificada y muy pubescente. Células subcuadradas con paredes rectas. Sin estomas. Pelos estrellados muy raros. Escamas, pelos y sus formas transicionales iguales a los del pecíolo.

\section{Cheilanthes obducta Mett. ex Kuhn}

Figuras 2, 23, $26 \mathrm{~F}$

Lámina - Epidermis unistrata; cutícula gruesa, lisa y con corpúsculos grasos de aspecto laminar y globoso. Epifilo, con células isodiamétricas y abundantes vesículas lipídicas, paredes sinuosas con engrosamientos celulósicos globosos en los ángulos. En transcorte, células subcuadradas, otras rectangulares, con paredes gruesas. Hipofilo con 
células isodiamétricas, sinuosas y sin engrosamientos celulósicos; en transcorte las paredes son gruesas. Lámina hipostomática; estomas elevados, otros a nivel, con cloroplastos y vesículas lipídicas; mayormente anomocíticos, también polocíticos; varios estomas comparten igual célula subsidiaria. Indumento densamente pubescente. Sobre el epifilo, pelos eglandulares pluricelulares ramificados, pedunculados y con estriaciones paralelas, hacia proximal las ramificaciones son cónicas, hacia distal acintadas. Hipofilo además, con pelos glandulares pluricelulares con cabeza cilíndrica unicelular.

Pseudoindusio - Formado por el margen reflexo del epifilo. De consistencia escariosa y borde entero. Características histológicas y pelos similares a las del haz foliar.

Raquis - Epidermis unistrata; cutícula gruesa, lisa y con vesículas grasas. Células subrectangulares, con paredes rectas a curvas. Igual tipo de estomas que el hipofilo, pero muy escasos. Pelos eglandulares ramificados y glandulares iguales a los de la lámina, además pelos unicelulares cónicos cortos, largos y muy largos.

Pecíolo - Epidermis unistrata; cutícula delgada y lisa. Células rectangulares con paredes rectas y lignificadas. Estomas ausentes. Aislados pelos eglandulares unicelulares y pluricelulares ramificados cónicos. Base del pecíolo, en contacto con el rizoma, con un mechón muy largo de tricomas formado por pelos y escamas: pelos ramificados en diferentes estados de desarrollo, pelos unicelulares simples y escamas basifijas, lineallanceoladas y triangular-lanceoladas y ápice cónico, ambas con margen pauci-dentado.

Rizoma - Epidermis unistrata, muy escamosa. Células subcuadradas, pared delgada y ligeramente recta. Estomas ausentes. Escasos pelos eglandulares estrellados y unicelulares cilíndricos (estos últimos se encontraron siempre sueltos, por lo que probablemente, sean porciones de los pelos estrellados). Escamas basifijas, ovado-lanceoladas a ovado-deltoideas y margen con ramificaciones pilíferas las que aumentan hacia distal, el ápice se prolonga con densas ramificaciones de pelos pluricelulares.

Familia Salviniaceae

\section{Azolla cristata Kaulf.}

Figura $24 \mathrm{I}-\mathrm{K}$

26. Azolla filiculoides Lam.

Figuras 24 A-H, 28 A, B, G.

Lámina bilobada (con un lóbulo emergente y el otro sumergido) - Epidermis unistrata, cutícula delgada y lisa. Epifilo e hipofilo con celulas redondeadas, papiliformes, rectangulares a subcuadradas hasta triangulares, con corpúsculos densos y granulares, muchos de ellos en las células de la zona de unión entre los dos lóbulos. Epidermis superior del lóbulo emergente de $A$. filiculoides con células alargadas de aspecto papiloso mientras que en $A$. cristata, cada célula epidérmica remata en una papila. Células marginales del lóbulo emergente con glóbulos grandes, compactos y pigmentados, producto de la acción de microorganismos (colonias de Anabaena sp.) que viven en simbiosis con estas especies (Di Fulvio 1956). Lámina anfistomática. Estomas a nivel y anomocíticos. Células oclusivas orientadas perpendicularmente al poro central; cuando en un estoma adulto las paredes contiguas de las células oclusivas se lisan, el estoma semeja un anillo; éstos últimos, con mayor frecuencia, en los márgenes de la lámina. Indumento ausente en A. filiculoides; en $A$. cristata es netamente papiloso. Papilas uni-bicelulares, algunas hundidas y otras a nivel de la epidermis.

Indusio - Conformado por una membrana reticulada. Eje sumergido - Epidermis unistrata y glabra. Cutícula, cuando existe, delgada y lisa. Células poligonales, subcuadradas a rectangulares con características similares a la zona de unión de los lóbulos foliares. Estomas ausentes.

Raíz - Epidermis unistrata, con células subrectangulares (en transcorte, netamente cuadrangulares). Pelos unicelulares, absorbentes y transparentes, dispuestos en hileras, algunos ligeramente ramificados en sus extremos. Cutícula ausente. Raíces jóvenes con pilorriza, conformada por una doble bolsa con células marginales oblongas.

Familia Woodsiaceae

27. Cystopteris fragilis (L.) Bernh.

Figuras 1, 25, 26 I

Lámina - Epidermis unistrata; cutícula lisa y delgada. Epifilo con células alargadas, con ondas uniformes y amplias; sobre los nervios, células más angostas y de paredes rectas. Hipofilo con células alargadas o isodiamétricas, de paredes con sinuosidades curvas o cuadrangulares, irregulares; células marginales voluminosas, generalmente isodiamétricas y de aspecto papiloso, más conspicuas en el ápice de los lóbulos foliares. Lámina anfistomática; estomas elevados, polocíticos y anomocíticos, escasos en epifilo y frecuentes en el hipofilo. Además, estomas 
copolocíticos, diacíticos y tetracíticos restringidos al envés foliar. Pelos y escamas ausentes.

Indusio - Ovado a lanceolado, margen entero. En vista superficial, células alargadas o isodiamétricas con paredes rectas. Glabro.

Raquis - Células epidérmicas alargadas, de paredes rectas o levemente curvadas; cutícula lisa y delgada. Líneas laterales con estomas elevados, anomocíticos. Pelos glandulares, unicelulares con cabeza globosa estipitada o pluricelulares ramificados con los extremos glandulares. Pecíolo - Modelo epidérmico similar al de los raquis. Cutícula lisa y delgada. Líneas laterales que discurren a ambos lados. Pelos glandulares pluricelulares con cabeza globosa, con o sin estípite. Algunas escamas esparcidas, más frecuentes en la base, basifijas, concolores, pardo-claras, estrechamente triangulares y lanceoladas a ovado-lanceoladas; con pelos marginales o asentados directamente sobre la superficie de la escama que rematan en un extremo globoso; además pequeños pelos simples unicelulares principalmente sobre el margen de la escama.

Rizoma - Epidermis unistrata. Células epidérmicas de paredes engrosadas y pigmentadas, lumen celular muy reducido. Estomas ausentes. Pelos ausentes. Escamas basifijas, oscuras y esclerosadas, margen con algunas prolongaciones cuyos extremos finalizan en una célula glandular globosa a igual que el ápice de la escama.

Clave diferencial de los taxones de helechos y licófitas

1. Epidermis glabra o, a veces, con papilas

2. Estomas con células oclusivas perpendiculares al eje longitudinal del poro, a veces formando un anillo entorno a él, por disolución de las paredes celulares; excrescencias epicuticulares ausentes

3. Células del epifilo coronadas por papilas uni-bicelulares ..........................................Azolla cristata

3. Células del epifilo alargadas de aspecto papiloso ................................................. Azolla filiculoides

2. Estomas con células oclusivas paralelas al eje longitudinal del poro; excrescencias epicuticulares hialinas y algo globosas presentes

4. Estomas confinados a los márgenes de la lámina; epidermis de la lámina con engrosamientos discontinuos en la pared celular ...................................................................... Huperzia saururus

4. Estomas en toda la lámina; epidermis de la lámina con engrosamientos continuos en la pared celular

5. Esporangio con paredes celulares que presentan engrosamientos discontinuos e irregulares, de aspecto globoso; esporofilo con poros de ventilación ......................... Lycopodium clavatum

5. Esporangio con paredes celulares que presentan engrosamientos continuos y regulares; esporofilo sin poros de ventilación .................................................... Lycopodium thyoides

1. Epidermis con indumento piloso y/o escamoso

6. Epidermis con pelos glandulares y eglandulares, sin escamas

7. Epidermis con estomas desmocíticos y pericíticos; láminas con pelos unicelulares laminares

8. Láminas y ejes foliares densamente pilosos ............... Anemia tomentosa (incluyendo las 2 variedades)

8. Láminas y ejes foliares pubescentes ............................................................... Anemia australis

7. Epidermis con estomas paracítico-criptoporos; láminas sin pelos laminares

9. Pelos simples uniseriados cónicos verrucosos en los tallos aéreos; estomas caulinares

con cámara respiratoria externa ..................................................... Equisetum giganteum

9. Pelos dendroides en los tallos aéreos; estomas caulinares sin cámara respiratoria ..... Equisetum bogotense

6. Epidermis con pelos y escamas

10. Escamas peltadas

11. Soros con indusio; estomas estaurocíticos

11. Soros sin indusio; estomas de otro tipo

Nephrolepis cordifolia

12. Frondes con pelos solamente unicelulares eglandulares; epidermis del pecíolo con idioblastos y puntuaciones notables; microescamas aracniformes ........... Elaphoglossum gayanum

12. Frondes con distintos tipos de pelos: glandulares y eglandulares; epidermis sin idioblastos, puntuaciones poco conspicuas; microescamas cuando presentes, de otras formas

13. Hipofilo sin escamas, sólo con algunas microescamas; frondes con pelos glandulares y eglandulares; escamas rizomáticas concoloras o un poco más claras en el margen; hidatodos en el margen de la lámina. . Serpocaulon gilliesii 
13. Hipofilo escamoso, microescamas ausentes; frondes con pelos glandulares; escamas rizomáticas marcadamente bicolores; hidatodos ausentes Pleopeltis pinnatifida

10. Escamas basifijas

14. Epidermis del pecíolo y raquis papilosa

15. Indusio glabro, margen fimbriado; microescamas foliares de forma irregular; pelos foliares simples y ramificados Blechnum cordatum

15. Indusio piloso, margen papiloso; microescamas foliares filiformes; pelos foliares simples Blechnum hastatum

14. Epidermis del pecíolo y raquis, sin papilas

16. Soros indusiados

17. Indusio glabro; láminas anfistomáticas; frondes con pelos ramificados ...... Cystopteris fragilis

17. Indusio piloso; láminas hipostomáticas; frondes sin pelos ramificados ... Asplenium monanthes

16. Soros exindusiados, a veces protegidos por el margen reflexo

18. Indumento muy evidente formado por escamas y pelos variados

19. Ejes foliares pilosos; epidermis foliar con pelos ramificados; escamas rizomáticas con prolongaciones pilíferas Cheilanthes obducta

19. Ejes foliares escamosos; epidermis foliar con otro tipo de pelos; escamas rizomáticas con el margen entero..... Cheilanthes myriophylla

18. Indumento glabrescente inconspicuo

20. Estomas del raquis anómalos; pseudoindusio con el margen fimbriado ... Cheilanthes marginata

20. Estomas del raquis, cuando presentes, normales; pseudoindusio con el margen más o menos entero, nunca fimbriado

21. Frondes con pelos glandulares secretores de cera; pseudoindusio cubriendo los soros del hipofilo

22. Hipofilo con pelos glandulares secretores de cera blanca.

Argyrochosma nivea var. nivea

22. Hipofilo con pelos glandulares secretores de cera amarilla

Argyrochosma nivea var. flava

21. Frondes sin pelos glandulares secretores de cera o glabros o con pelos de otros tipos; pseudoindusio con los soros en la cara interna

23. Escamas rizomáticas concolores; microescamas; pelos ramificados; dendroides foliares ausentes; estomas levemente hundidos en la epidermis; células epidérmicas interrumpidas por idioblastos esclerenquimáticos a nivel de las nervaduras; células epidérmicas del epifilo con protuberancias en las paredes tangenciales internas

24. Escamas rizomáticas de margen entero

25. Pelos glandulares entre los esporangios y en la base de las pínulas; cutícula lisa sin sustancias adcrustantes ... Adiantum orbignyanum

25. Pelos glandulares ausentes; cutícula rugosa con sustancias adcrustantes Adiantum raddianum

24. Escamas rizomáticas de margen ciliado

26. Láminas y pseudoindusios glabros .... Adiantum thalictroides var. thalictroides

26. Láminas y pseudoindusios con pelos glandulares y eglandulares ............................ Adiantum thalictroides var. hirsutum

23. Escamas rizomáticas bicolores; microescamas en láminas y ejes foliares; pelos ramificados dendroides en las frondes; estomas al mismo nivel que las células epidérmicas, éstas sin idioblastos esclerenquimáticos; células epidérmicas del epifilo con paredes tangenciales internas lisas Adiantopsis chlorophylla 


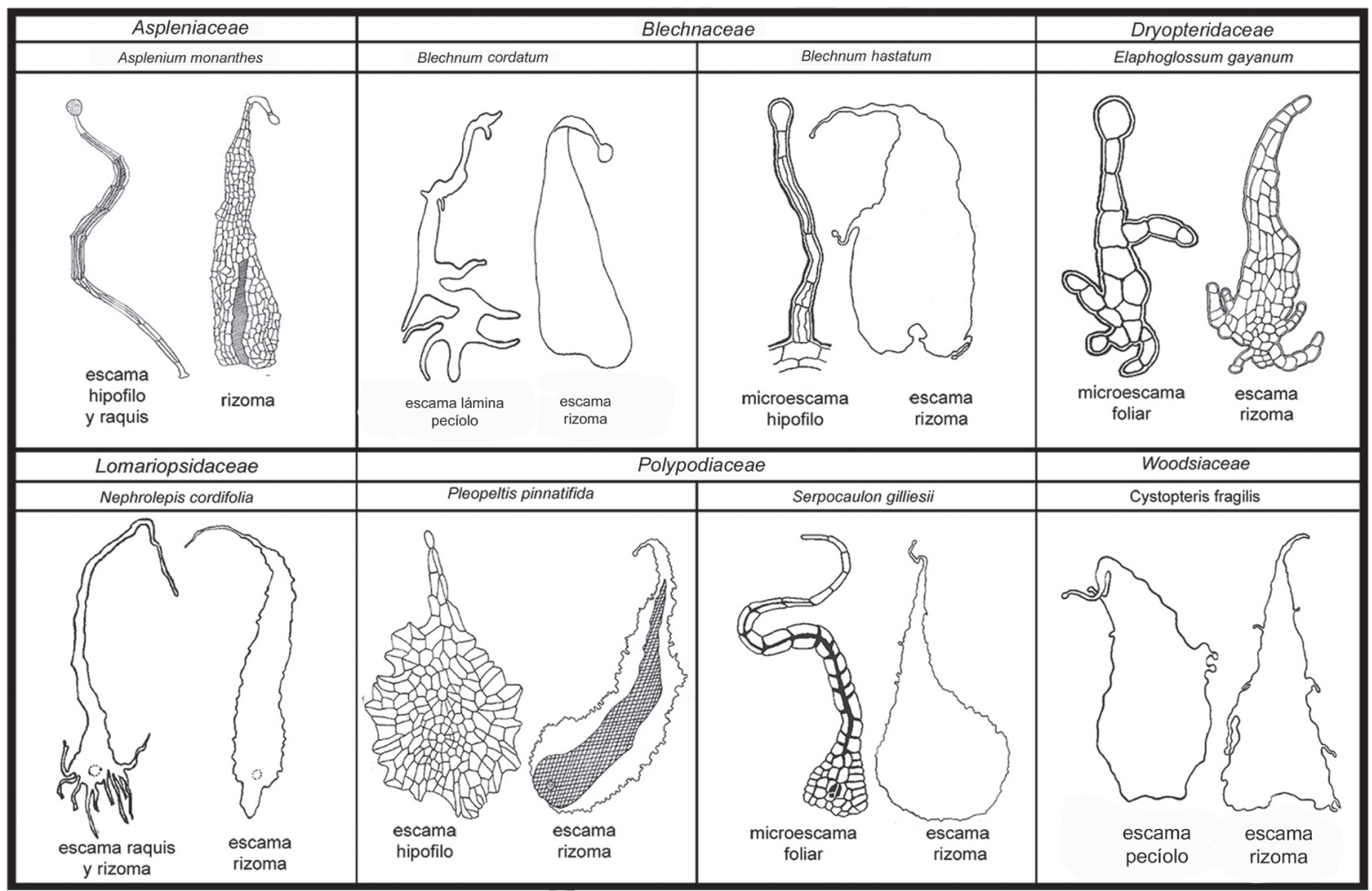

Figura 1. Tipos de escamas y microescamas en helechos medicinales de la Provincia de Córdoba, Argentina.

Figure 1. Types of scales and microscales in medicinal ferns from Córdoba Province, Argentina.

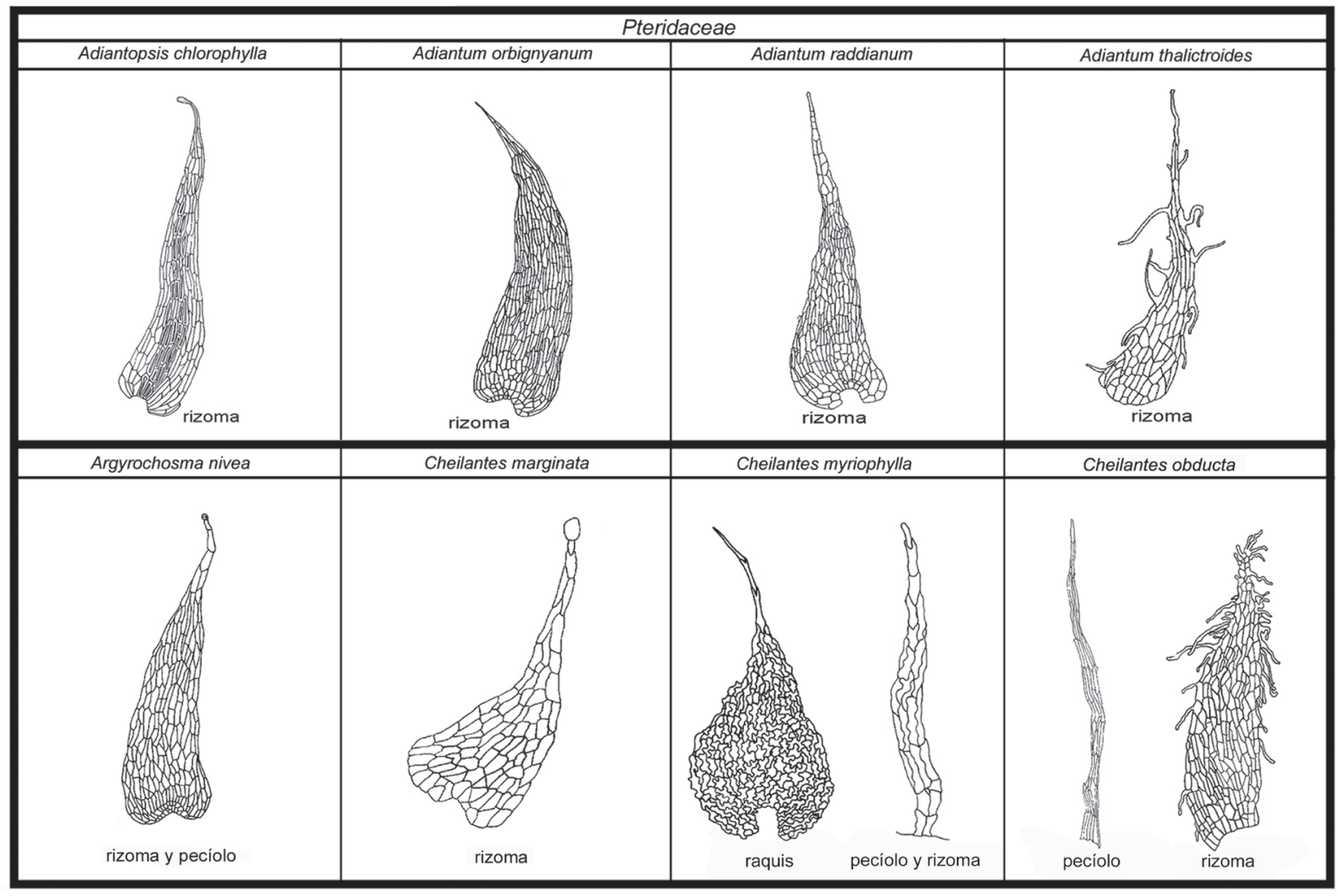

Figura 2. Tipos de escamas en Pteridaceae de helechos y licófitas medicinales de la Provincia de Córdoba, Argentina.

Figure 2. Types of scales in Pteridaceae of medicinal ferns and licophytes from Córdoba Province, Argentina. 


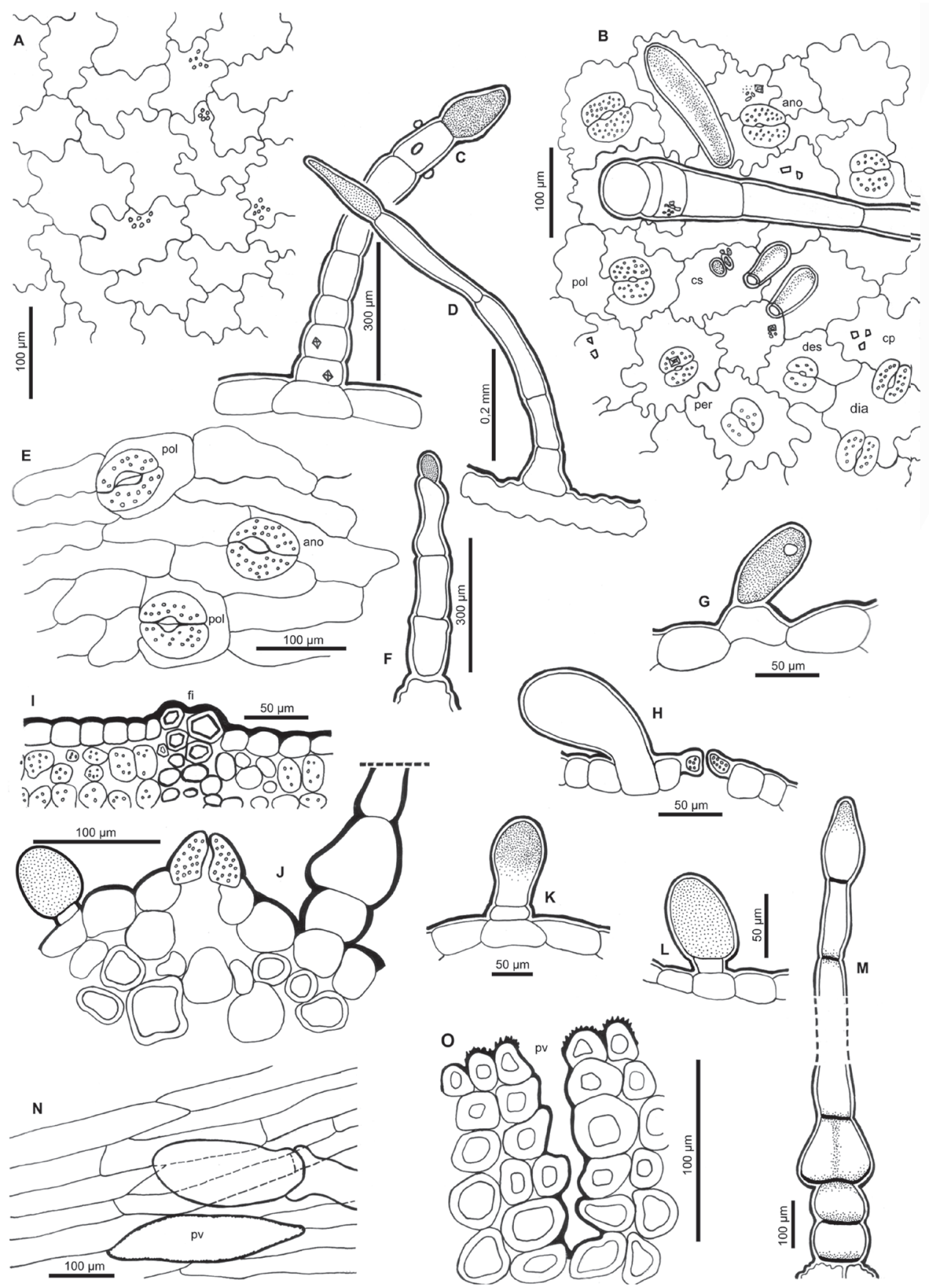

Figura 3. Anemia australis (Luján 106). A. Epifilo. B. Hipofilo con cristales de sílice (cs), cristales prismáticos (cp), estomas anomocíticos (ano), desmocíticos (des), diacíticos (dia), pericíticos (per) y polocíticos (pol), y pelos eglandulares. C, F, M. Pelos glandulares foliares y rizomáticos. D. Pelo glandular del pecíolo. E. Epidermis del raquis con estomas polocíticos (pol) y anomocíticos (ano). G. Pelo glandular de la lámina. H. Pelo eglandular laminar. I. Epifilo, epidermis con protrusión de fibras. J. Transcorte de raquis, con estoma sobreelevado, pelo glandular y base de otro pelo. K. Pelo glandular foliar. L. Pelo glandular del pecíolo. N. Epidermis peciolar con base de pelo y poro de ventilación (pv). O. Poro de ventilación (pv) en corte transversal.

Figure 3. Anemia australis (Luján 106). A. Upper epidermis. B. Lower epidermis with crystals of silica, (cs), prismatic crystals (cp), anomocytic (ano), desmocytic (des), diacytic (dia), pericytic (per), and polocytic (pol) stomata, and non-glandular hairs. C, F, M. Leaf and rhizome glandular hairs. D. Petiole glandular hair. E. Rachis epidermis with polocytic (pol) and anomocytic (ano) stomata. G. Lamina glandular hair. H. Lamina non-glandular hair. I. Upper epidermis with fibers protrusion. J. Cross section of the rachis, with stoma raised above the epidermis, glandular hair and base of other hair. K. Leaf glandular hair. L. Petiole glandular hair. N. Petiole epidermis showing a hair base and a ventilation pore (pv), in surface view. O. Ventilation pore in cross section (pv). 


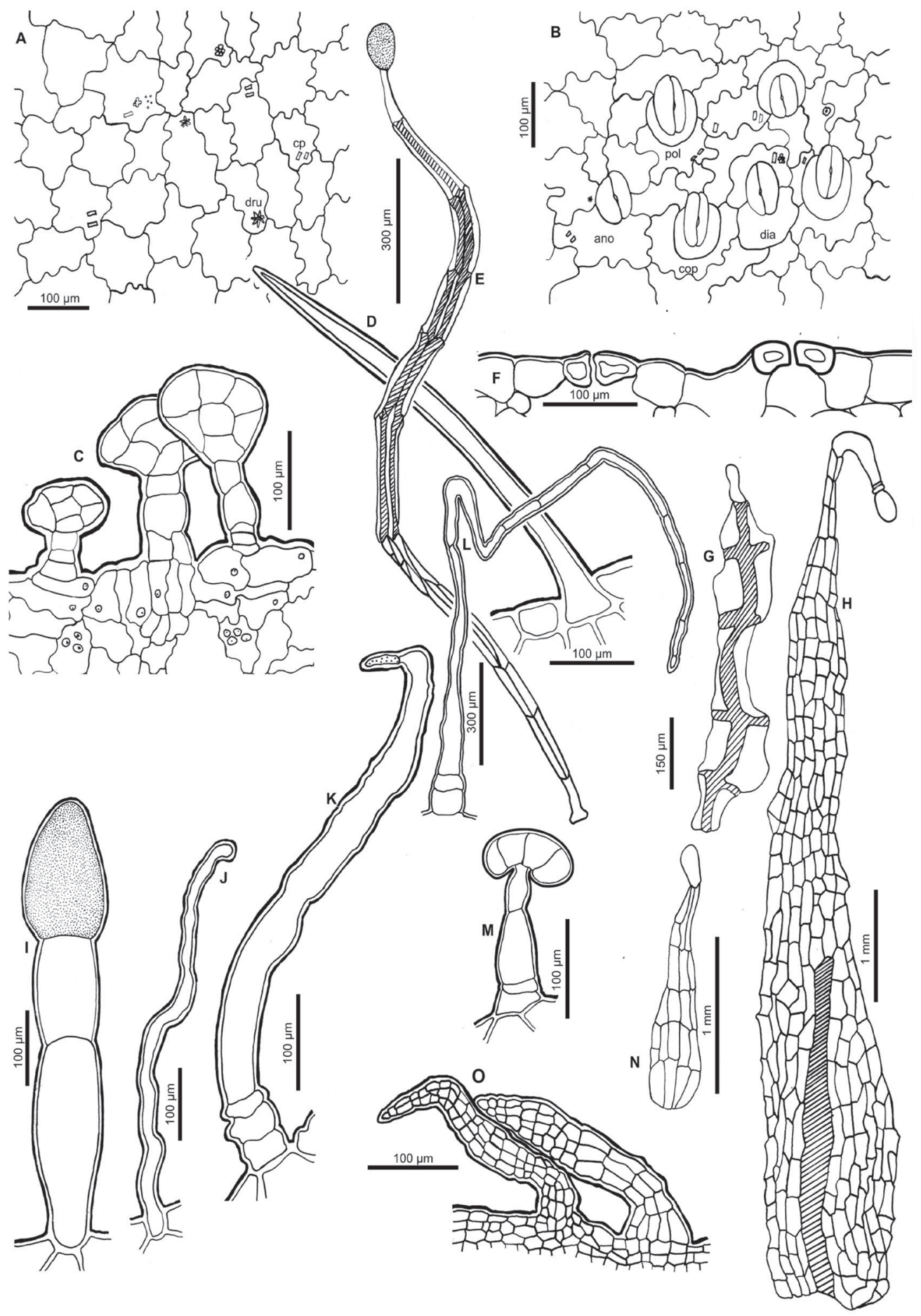

Figura 4. Asplenium monanthes (Morero 84) A. Epifilo con cristales prismáticos y drusas. B. Hipofilo con estomas copolocíticos (cop), polocíticos (pol), diacíticos (dia) y anomocíticos (ano). C, D, L. Pelos del indusio. E. Escama filiforme del hipofilo. F. Estomas a nivel y sobreelevados en transcorte foliar. G, N. Escamas del pecíolo. H. Escama rizomática. I, J. Pelos de la lámina. K. Pelo del pecíolo. M. Pelo del esporangio. O. Escamas jóvenes del rizoma.

Figure 4. Asplenium monanthes (Morero 84) A. Upper epidermis with prismatic crystals and druses. B. Lower epidermis with copolocytic (cop), polocytic (pol), diacytic (dia), and anomocytic (ano) stomata. C, D, L. Indusium hairs. E. Filiform scale of the lower epidermis. F. Stomata at level with the epidermis and raised above it, in cross section. G, N. Petiole scales. H. Rhizome scale. I, J. Leaf hairs. K. Petiole hair. M. Sporangium hair. O. Rhizome young scales. 

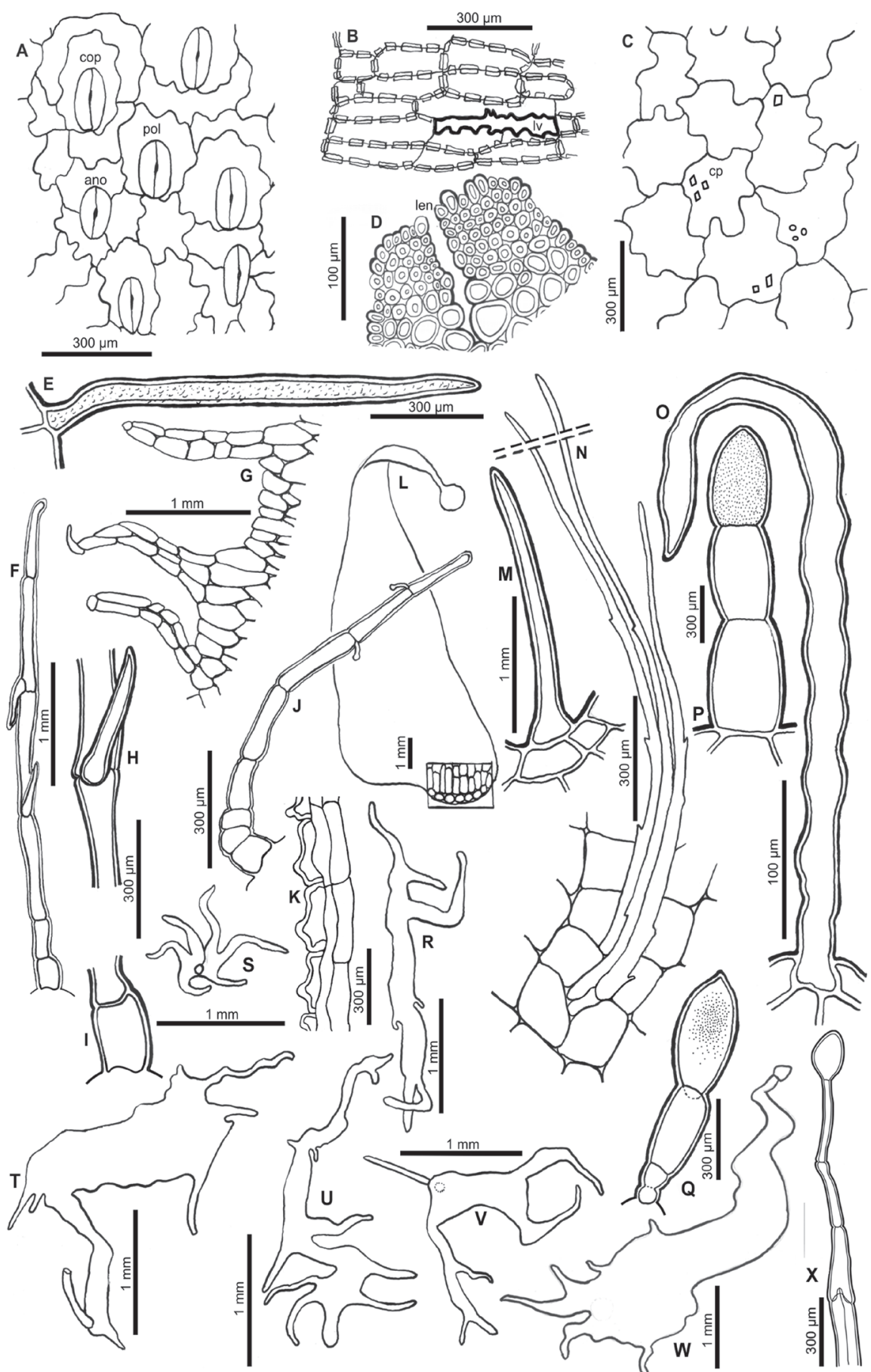

Figura 5. Blechnum cordatum (Morero 161). A. Hipofilo con estomas copolocíticos (cop), polocíticos (pol) y anomocíticos (ano). B. Epidermis del pecíolo, con línea de ventilación (lv). C. Epifilo, con cristales prismáticos (cp). D. Lenticela (len) adulta. E, M, O. Pelos eglandulares unicelulares. F, J. Pelos ramificados foliares. G. Margen fimbriado del indusio. H, I. Detalles del pelo mostrado en F. J. Pelo uniseriado. K. Epidermis papilosa del pecíolo. L. Escama del rizoma. N. Pelos filiformes. P, Q. Pelos glandulares. R-V. Microescamas irregulares. W. Escama del pecíolo. X. Detalle del ápice de una escama rizomática.

Figure 5. Blechnum cordatum (Morero 161). A. Lower epidermis with copolocytic (cop), polocytic (pol), and anomocytic (ano) stomata. B. Petiole epidermis with respiratory line (lv). C. Upper epidermis with prismatic crystals (cp). D. Mature lenticel (len). E, M, O. Non-glandular unicellular hairs. F, J. Leaf branched hairs. G. Fimbriate margin of the indusium. H, I. Details of the hair shown in F, K. Papillas of the petiole epidermis. L. Rhizome scale. N. Filiform hairs. P, Q. Glandular hairs. R-V. Irregular microscales. W. Petiole scale. X. Apex detail of a rhizome scale. 


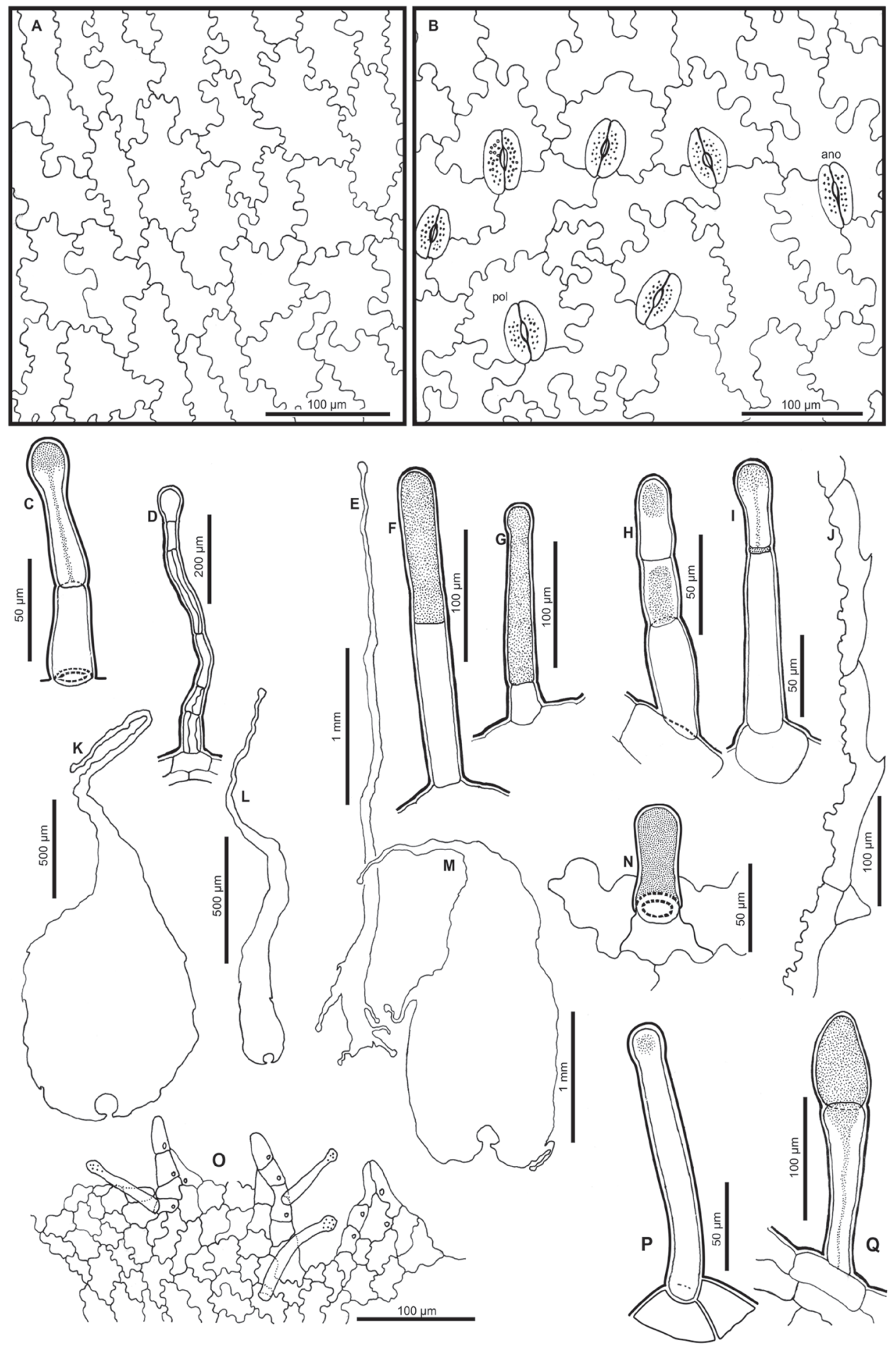

Figura 6. Blechnum hastatum (Morero 143). A. Epifilo. B. Hipofilo, con estomas polocíticos (pol) y anomocíticos (ano). C, F, G, H, I, N, Q. Pelos glandulares de la lámina. D. Microescama del hipofilo. E. Escama del pecíolo. J. Margen de una pínnula. K, L. Escamas del raquis. M. Escama rizomática. O. Indusio, mostrando el margen papiloso y pelos glandulares. P. Pelo glandular del pecíolo.

Figure 6. Blechnum hastatum (Morero 143). A. Upper epidermis. B. Lower epidermis with polocytic (pol) and anomocytic (ano) stomata. C, F, G-I, N, Q. Leaf glandular hairs. D. Microscale of the lower epidermis. E. Petiole scale. J. Margin of a pinnule. K, L. Rachis scales. M. Rhizome scale. O. Indusium, showing papillose margin and glandular hairs. P. Petiole glandular hair. 

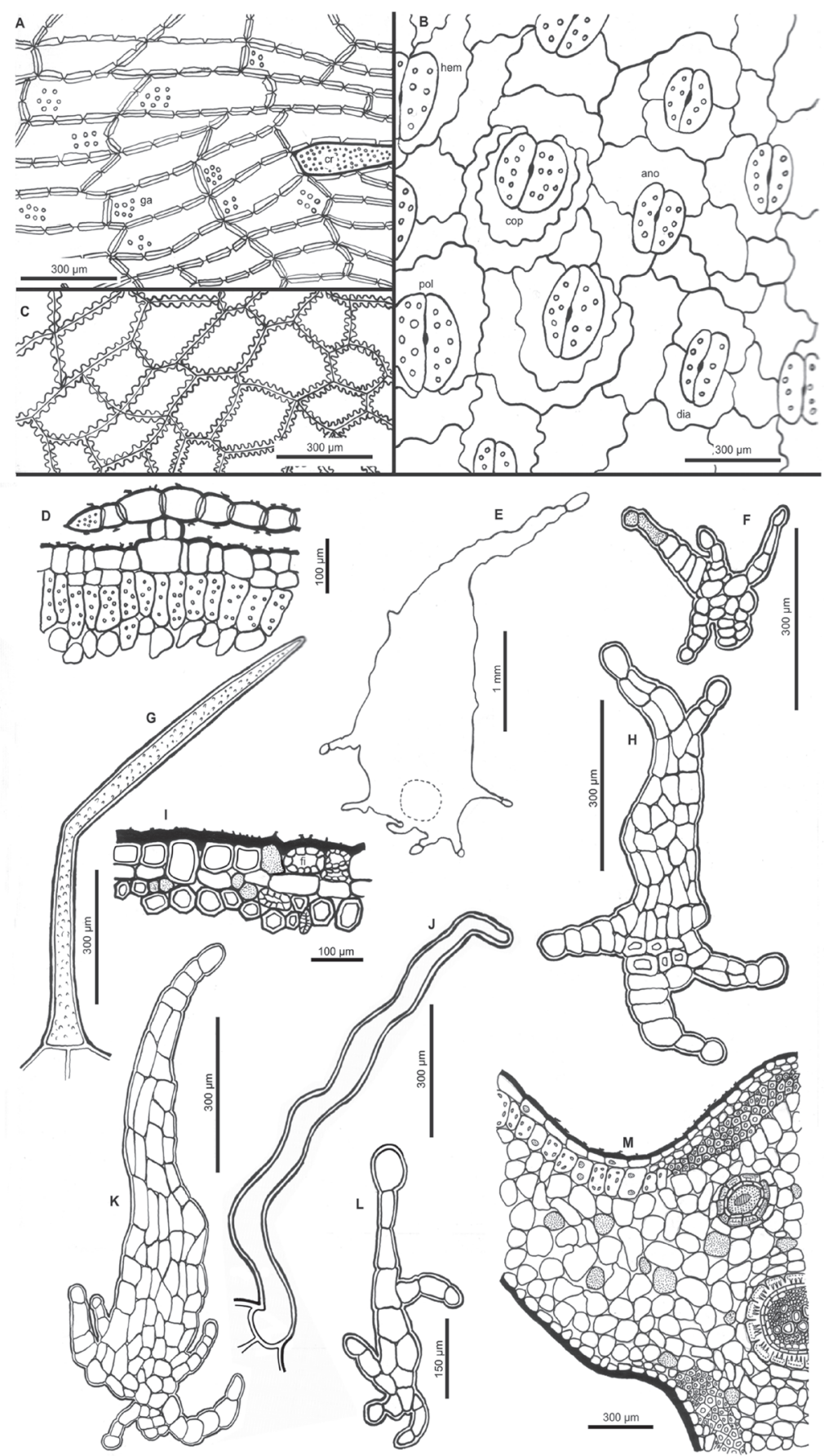

Figura 7. Elaphoglossum gayanum (Barboza 783). A. Epidermis del pecíolo (ga: granos de almidón; cr: areniscas cristalinas). B. Hipofilo con estomas polocíticos (pol), copolocíticos (cop), anomocíticos (ano), diacíticos (dia) y hemiparacíticos (hem). C. Epifilo (obsérvese la pared muy sinuosa y la laminilla media recta). D. Escama pedicelada en transcorte. E, K. Escamas rizomáticas, contorno y entramado celular, respect. F, H, L. Microescamas aracniformes foliares. G. Pelo unicelular de la hoja. I. Fibras (fi) en la epidermis de pecíolo, en transcorte. J. Pelo foliar acintado. M. Epidermis biestratificada sobre el nervio medio de hoja, en transcorte.

Figure 7. Elaphoglossum gayanum (Barboza 783). A. Petiole epidermis (ga: starch granules; cr: crystal sands). B. Lower epidermis with polocytic (pol), copolocytic (cop), anomocytic (ano), diacytic (dia), and hemiparacytic (hem) stomata. C. Upper epidermis (observe the cell wall very sinuate and the straight middle lamella). D. Pedicellate scale in cross section. E, K. Rhizome scales, outline and cell reticulum, respect. F, H, L. Leaf arachnidoid microscales. G. Leaf unicelular hair. I. Epidermis with fibers (fi) in petiole cross section. J. Leaf hair stripe-like. M. Leaf epidermis biseriate on the main nerve, cross section. 

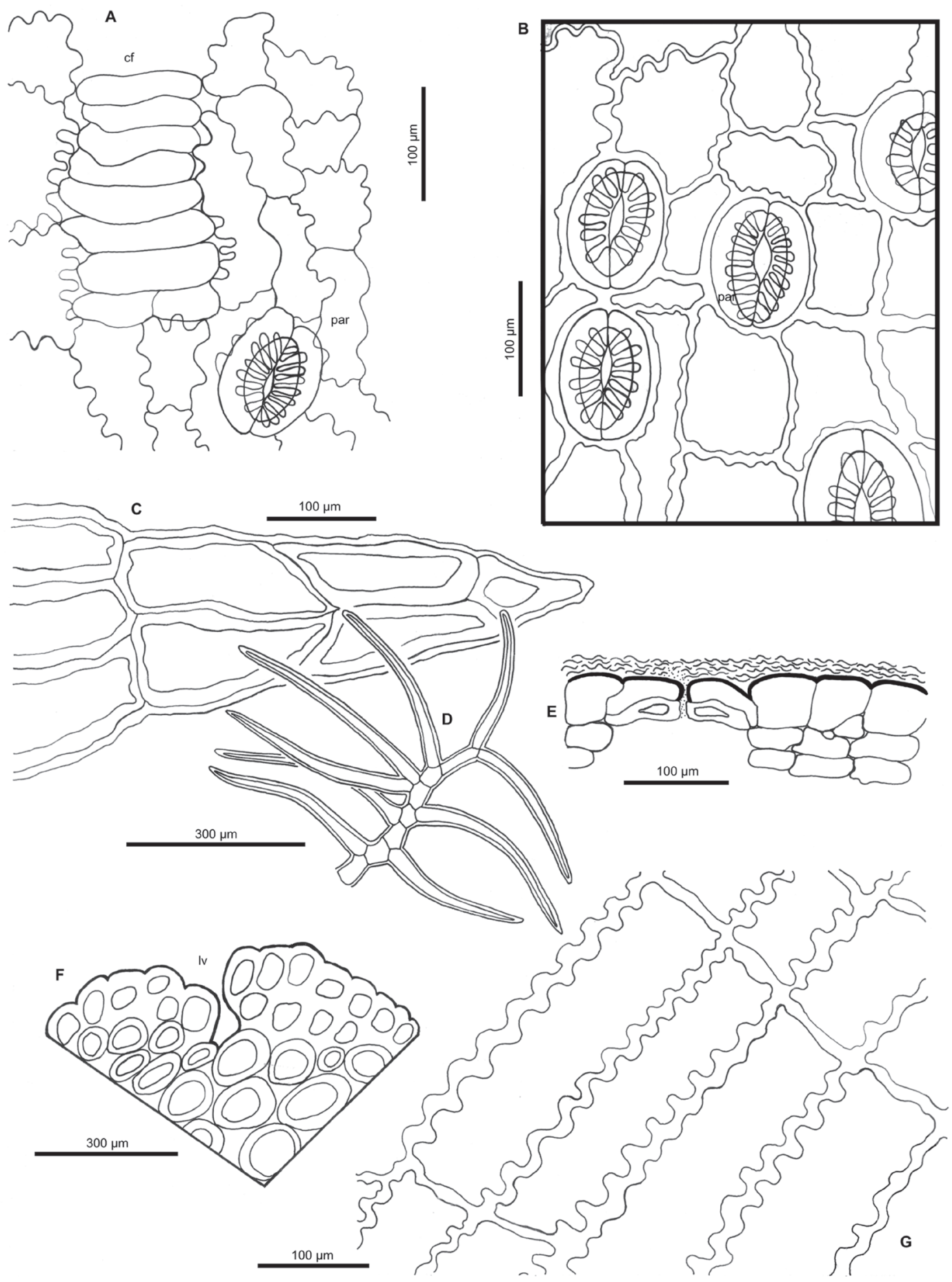

Figura 8. Equisetum bogotense (Zavala 3894). A. Hipofilo con estoma paracítico-criptoporo (par) y comisura foliar (cf). B. Epidermis caulinar. C. Ápice foliar. D. Pelo dendroide caulinar. E. Estoma caulinar con incrustaciones silíceas sobre la pared tangencial externa. F. Línea de ventilación (lv) de rizoma, en transcorte. G. Epidermis del rizoma.

Figure 8. Equisetum bogotense (Zavala 3894). A. Lower epidermis with paracytic-criptopore (par) stoma and leaf notch (cf). B. Stem epidermis. C. Leaf apex. D. Stem dendroid hair. E. Stem stoma with silica on the external tangential cell wall. F. Rhizome ventilation line (lv), cross section. G. Rhizome epidermis. 
A

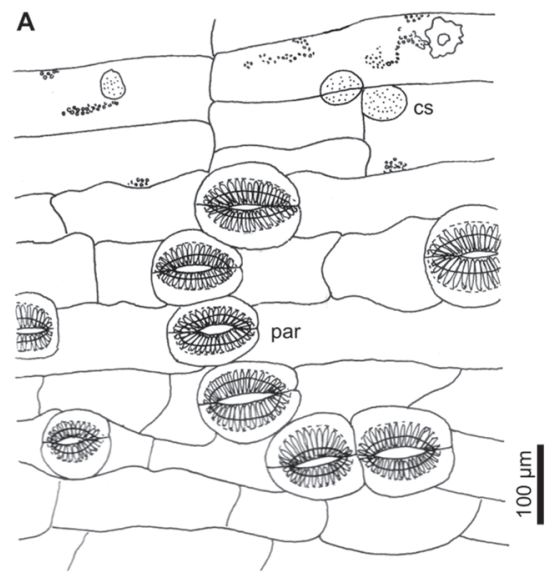

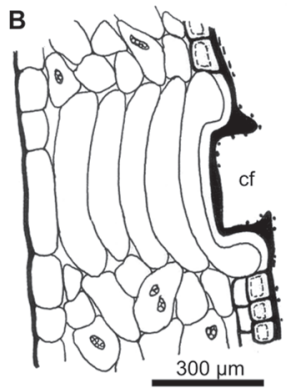
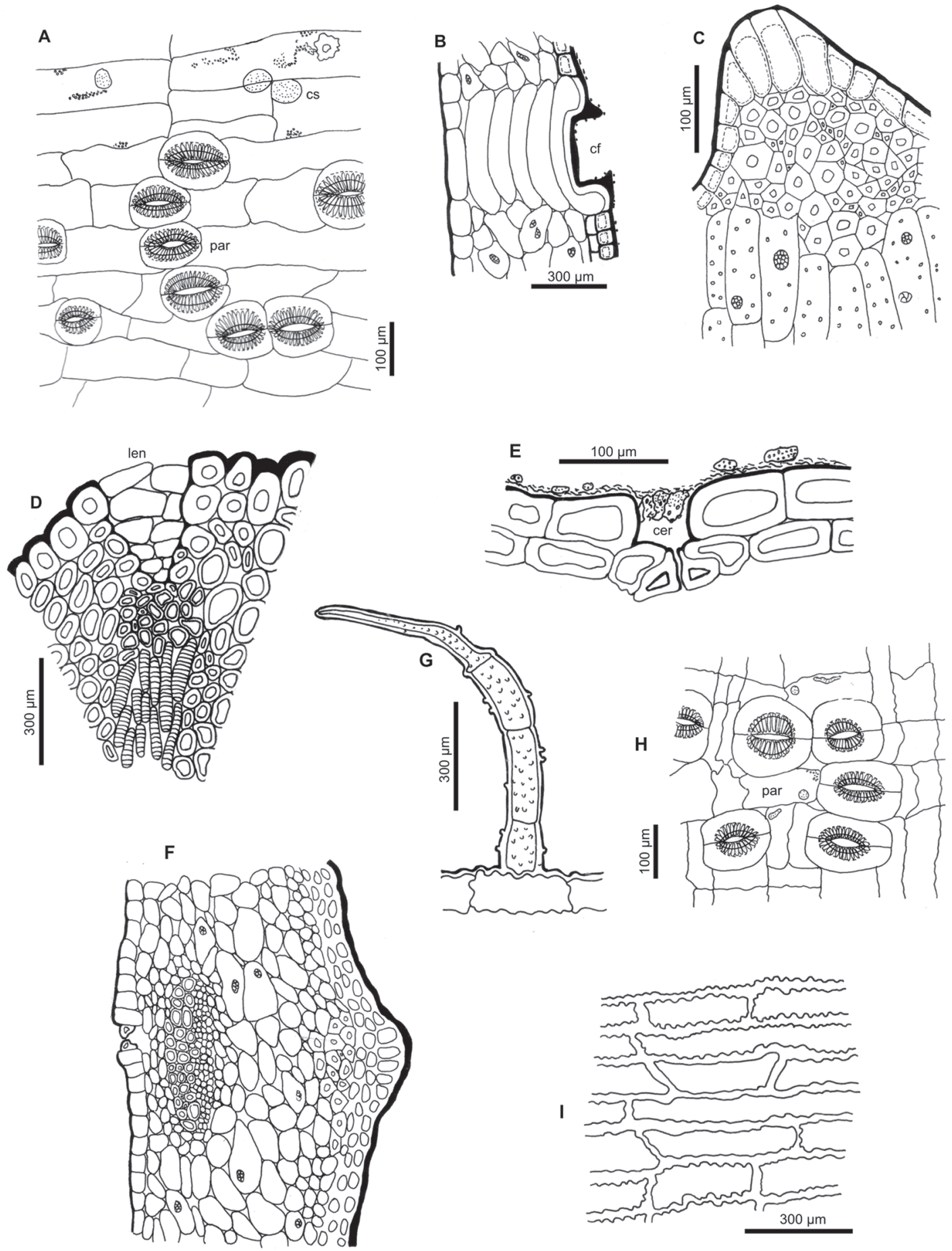

$300 \mu \mathrm{m}$

Figura 9. Equisetum giganteum (Luján 40). A. Hipofilo con estomas paracítico-criptoporos (par) y corpúsculos silíceos (cs). B. Detalle de comisura foliar (cf), con un sector de epidermis biestratificada. C. Transcorte de tallo a nivel de una carena. D. Lenticela en transcorte caulinar. E. Estoma caulinar hundido con cámara externa respiratoria (cer). F. Detalle de transcorte foliar. G. Pelo cónico del tallo. H, I. Epidermis de tallo aéreo y rizoma, respect.

Figure 9. Equisetum giganteum (Luján 40). A. Lower epidermis with paracytic-criptopore (par) stoma and silica (cs). B. Leaf notch (cf) in detail and a sector of biseriate epidermis. C. Stem ridge in cross section. D. Stem lenticel, cross section. E. Stem sunken stoma with external respiratory cavity (cer). F. Detail of leaf cross section. H. Stem conical hair. I, J. Aerial stem and rhizome epidermis, respect. 


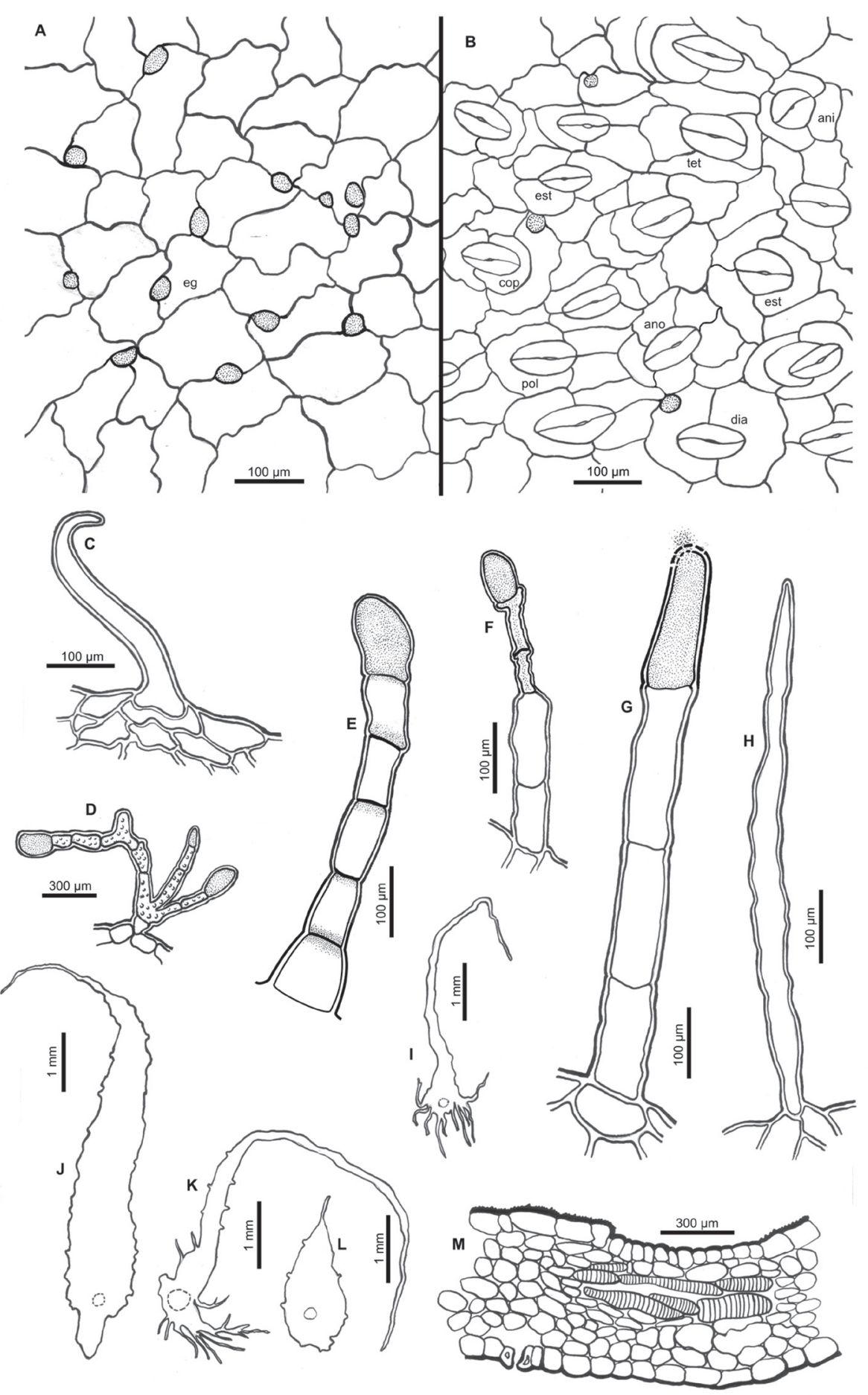

Figura 10. Nephrolepis cordifolia (Luján 107). A. Epifilo, con engrosamientos globosos (eg) en la pared celular. B. Hipofilo, con estomas copolocíticos (cop), polocíticos (pol), estaurocíticos (est), diacíticos (dia), tetracíticos (tet), anomocíticos (ano) y anisocíticos (ani). C. Pelo uncinado de epifilo. D. Pelo ramificado de la lámina. E, F. Pelos catenulados de la fronde. G. Pelo glandular del rizoma. H. Pelo unicelular cilíndrico. I. Escama del raquis. J-L. Escamas rizomáticas. M. Sector del mesofilo con un hidatodo.

Figure 10. Nephrolepis cordifolia (Luján 107). A. Upper epidermis, with globose thickenings (eg) in the cell wall. B. Lower epidermis with copolocytic (cop), polocytic (pol), staurocytic (est), diacytic (dia), tetracytic (tet), anomocytic (ano), and anisocytic (ani) stomata. C. Uncinate hair of upper epidermis. D. Leaf branched hair. E, F. Frond catenate hairs. G. Rhizome glandular hair. H. Unicellular cylindrical hair. I. Rachis scale. J-L. Rhizome scales. M. Mesophyll sector with hydathode. 

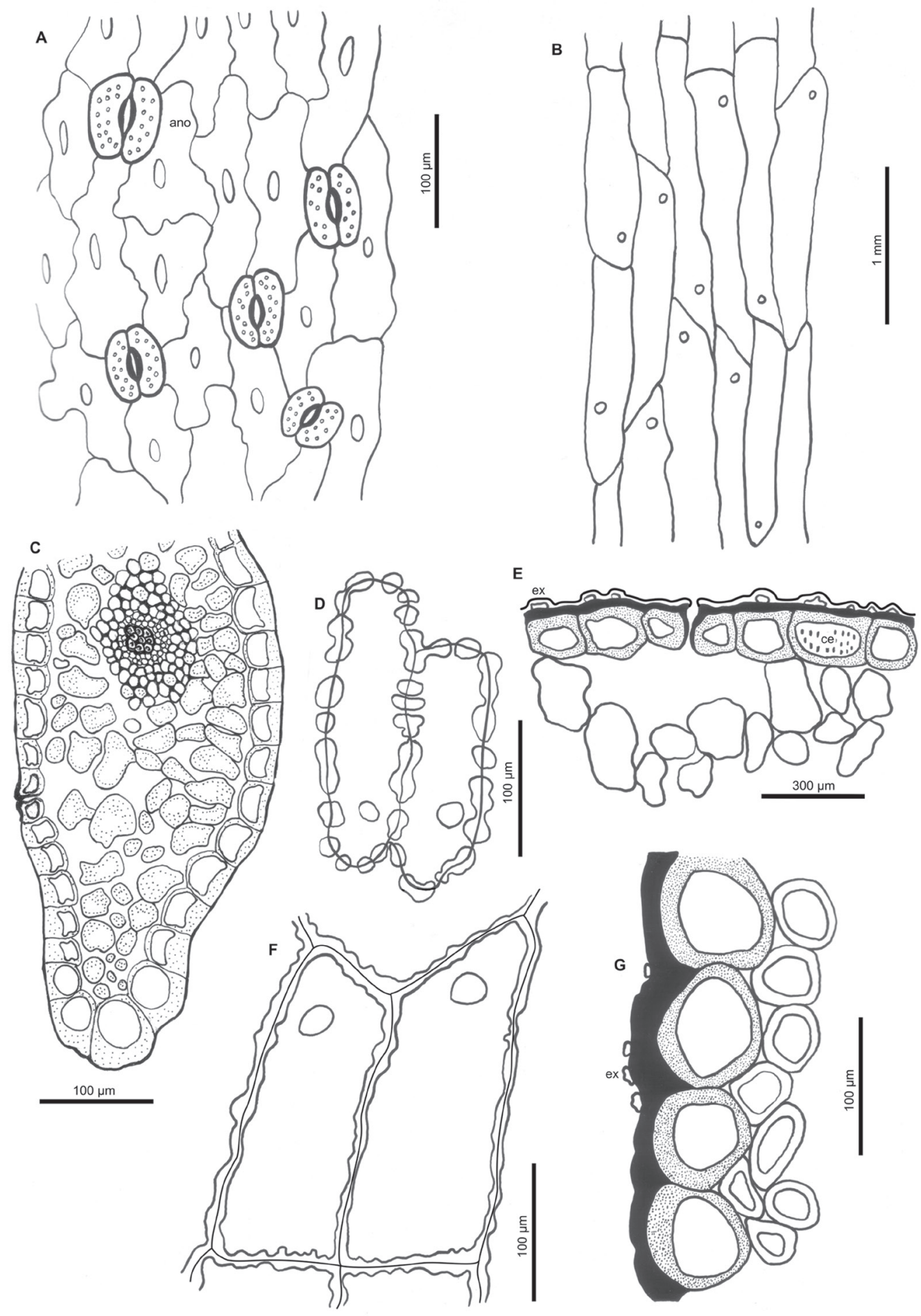

Figura 11. Huperzia saururus (Luján 73). A. Epifilo del trofofilo, con estomas anomocíticos (ano) y núcleos ahusados. B. Epidermis del tallo aéreo. C. Detalle de un sector del trofofilo en transección. D. Células epidérmicas del hipofilo mostrando las puntuaciones. E. Estoma del esporofilo, en transcorte (ce. célula lignificada, ex. excrescencia cuticular). F. Células epidémicas del tallo aéreo. G. Epidermis caulinar, en transección (ex. excrecencia cuticular). (C. figura tomada de Luján et al. 2000).

Figure 11. Huperzia saururus (Luján 73). A. Trophophyll upper epidermis with anomocytic (ano) stomata and fusiform nuclei. B. Aerial stem epidermis. C. Sector of trophophyll, cross section. D. Epidermal cells of lower epidermis showing pits. E. Sporophyll stoma, cross section (ce. lignified cell, ex. cuticle excrescence). F. Epidermal cells of aerial stem. G. Stem epidermis, cross section (ex. cuticle excrescence). (C. From Luján et al., 2000). 

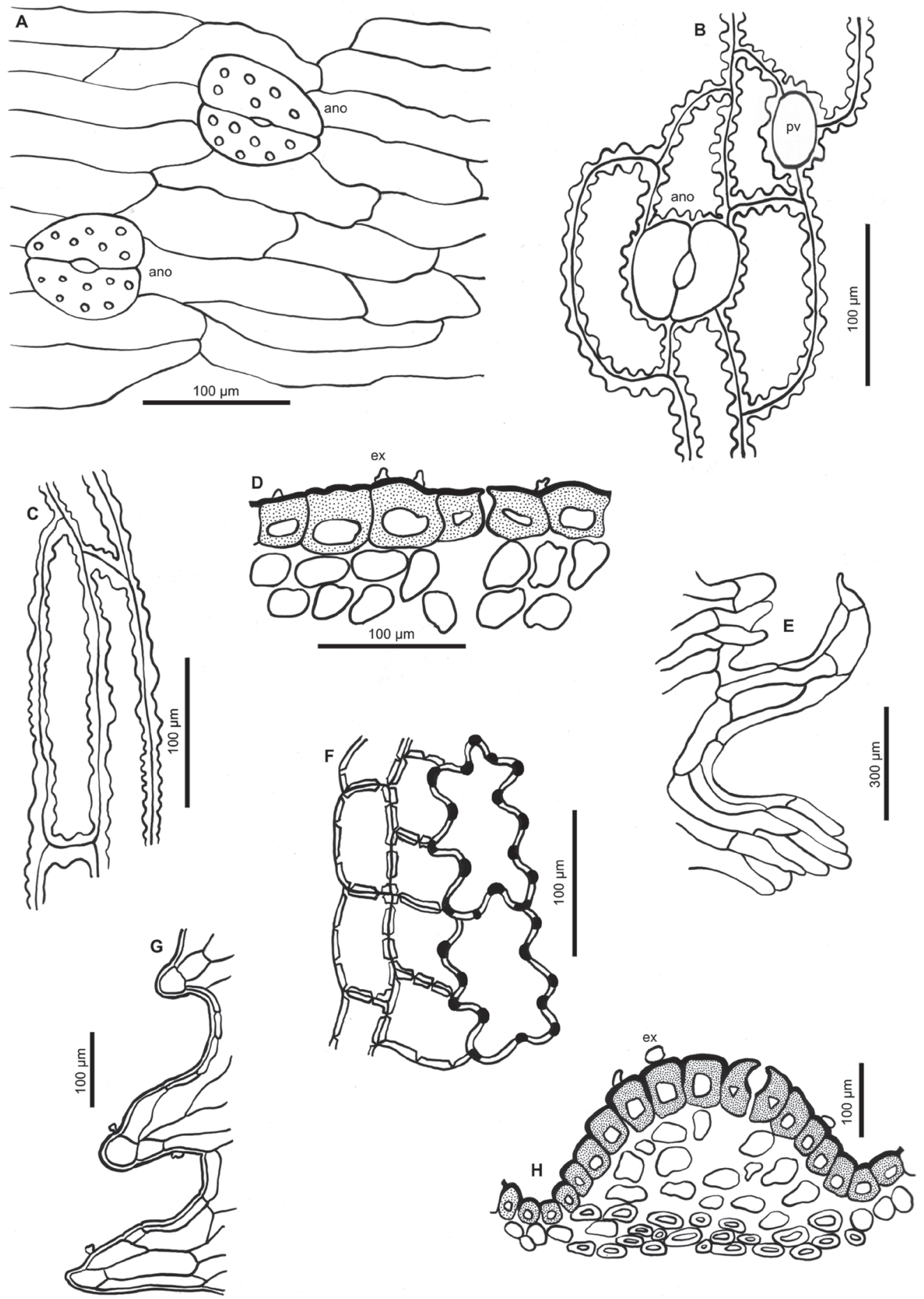

Figura 12. Lycopodium clavatum (Morero 152). A. Epidermis abaxial de un trofofilo, con estomas anomocíticos (ano). B. Epidermis adaxial del esporofilo, con poro de ventilación (pv). C. Epidermis abaxial del trofofilo, mostrando la pared celular sinuosa. D. Estoma foliar con excrecencia cuticular (ex), en transcorte. E. Sector del margen lacerado de un esporofilo. F. Epidermis del esporangio (células con paredes rectas y puntuaciones y células muy sinuosas con engrosamientos globosos). G. Epidermis denticulada de tallo postrado, corte longitudinal. H. Zona carinal de tallo erecto, en transcorte.

Figure 12. Lycopodium clavatum (Morero 152). A. Trophophyll lower epidermis with anomocytic (ano) stomata. B. Upper epidermis of the sporophyll with ventilation pore (pv). C. Trophophyll lower epidermis, showing sinuate cell wall. D. Leaf stoma with cuticle excrescence (ex), cross section. E. Sector of sporophyll lacerate margin. F. Sporangium epidermis (cells with straight cell wall and pits, and sinuate cells with globose thickenings). G. Denticulate epidermis of prostrate stem, longitudinal section. H. Stem ridge zone of erect stem, cross section. 


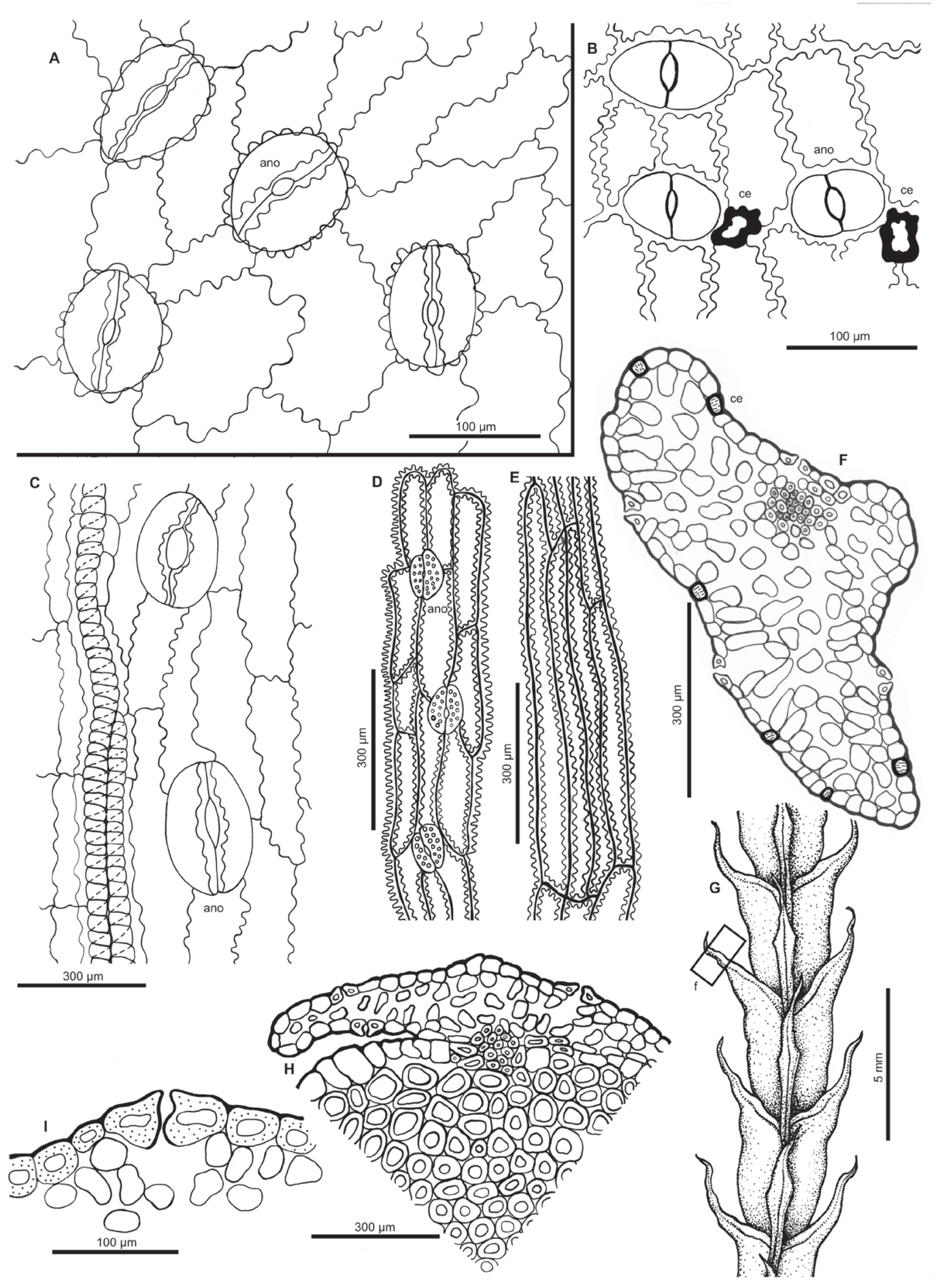

Figura 13. Lycopodium thyoides (Morero 150). A. Epidermis abaxial del trofofilo lateral, con estomas anomocíticos (ano). B. Epidermis adaxial del esporofilo, con células esclerenquimatosas (ce). C. Epidermis abaxial de un trofofilo lateral, a nivel del nervio medio. D. Epidermis adaxial de un trofofilo ventral, con sinuosidades en la pared celular. E. Epidermis de tallo postrado. F. Trofofilo, en transcorte zona marcada en G. G. Sector de rama vegetativa con hojas dimórficas y tetrásicas. H. Sector del tallo postrado y trofofilo lateral, en transección. I. Estoma foliar.

Figure 13. Lycopodium thyoides (Morero 150). A. Lower epidermis of lateral trophophyll with anomocytic (ano) stomata. B. Sporophyll upper epidermis with lignified cells (ce). C. Lower epidermis of lateral trophophyll, showing the midrib. D. Upper epidermis of ventral trophophyll with sinuate cell walls. E. Prostrate stem epidermis. F. Trophophyll in cross section, detail of sector shown in G. G. Sector of vegetative branch with dimorphic and tetrasic leaves. H. Prostrate stem and lateral trophophyll, cross section. I. Leaf stoma, cross section. 

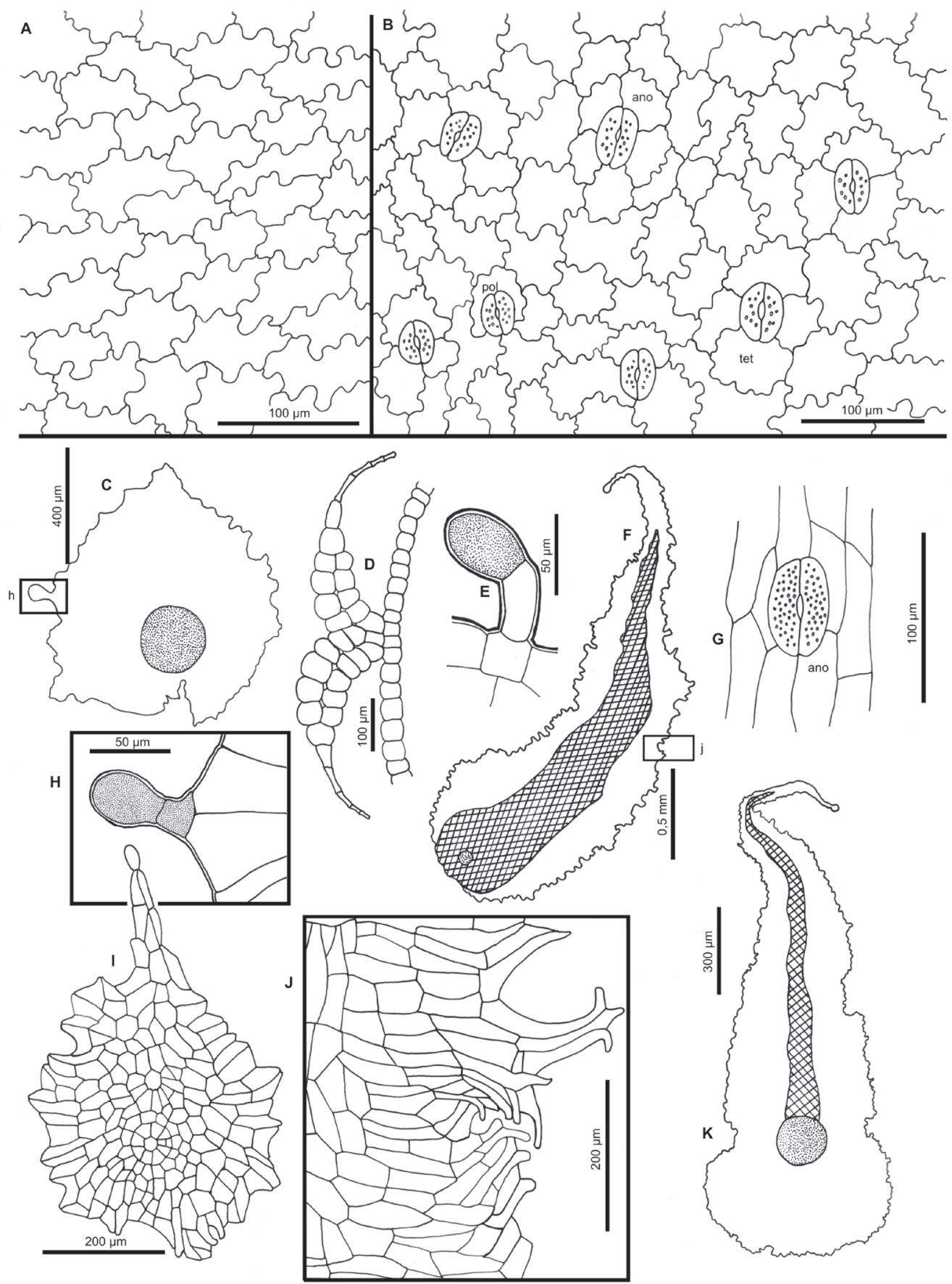

Figura 14. Pleopeltis pinnatifida (Morero 133). A. Epifilo de pinna. B. Hipofilo con estomas tetracíticos (tet), anomocíticos (ano) y polocíticos (pol). C. Escama del pecíolo. D. Transcorte por escama joven del rizoma. E. Pelo glandular del hipofilo. F, K. Escamas del rizoma con el área central esclerosada y pigmentada (zona cuadriculada). G. Estoma del pecíolo. H. Pelo glandular de la escama peciolar, según se indica en C. I. Escama del hipofilo con el retículo celular. J. Sector del margen de la escama rizomática, indicado en F.

Figure 14. Pleopeltis pinnatifida (Morero 133). A. Pinna upper epidermis. B. Lower epidermis with tetracytic (tet), anomocytic (ano), and polocytic (pol) stomata. C. Petiole scale. D. Rhizome young scale, cross section. E. Lower epidermis glandular hair. F, K. Rhizome scales, central area sclerified and dark (gridded zone). G. Petiole stoma. H. Petiole scale glandular hair, detail of zone shown in C. I. Lower epidermis scale showing cellular net. J. Sector of the rhizome scale margin, indicated in F. 

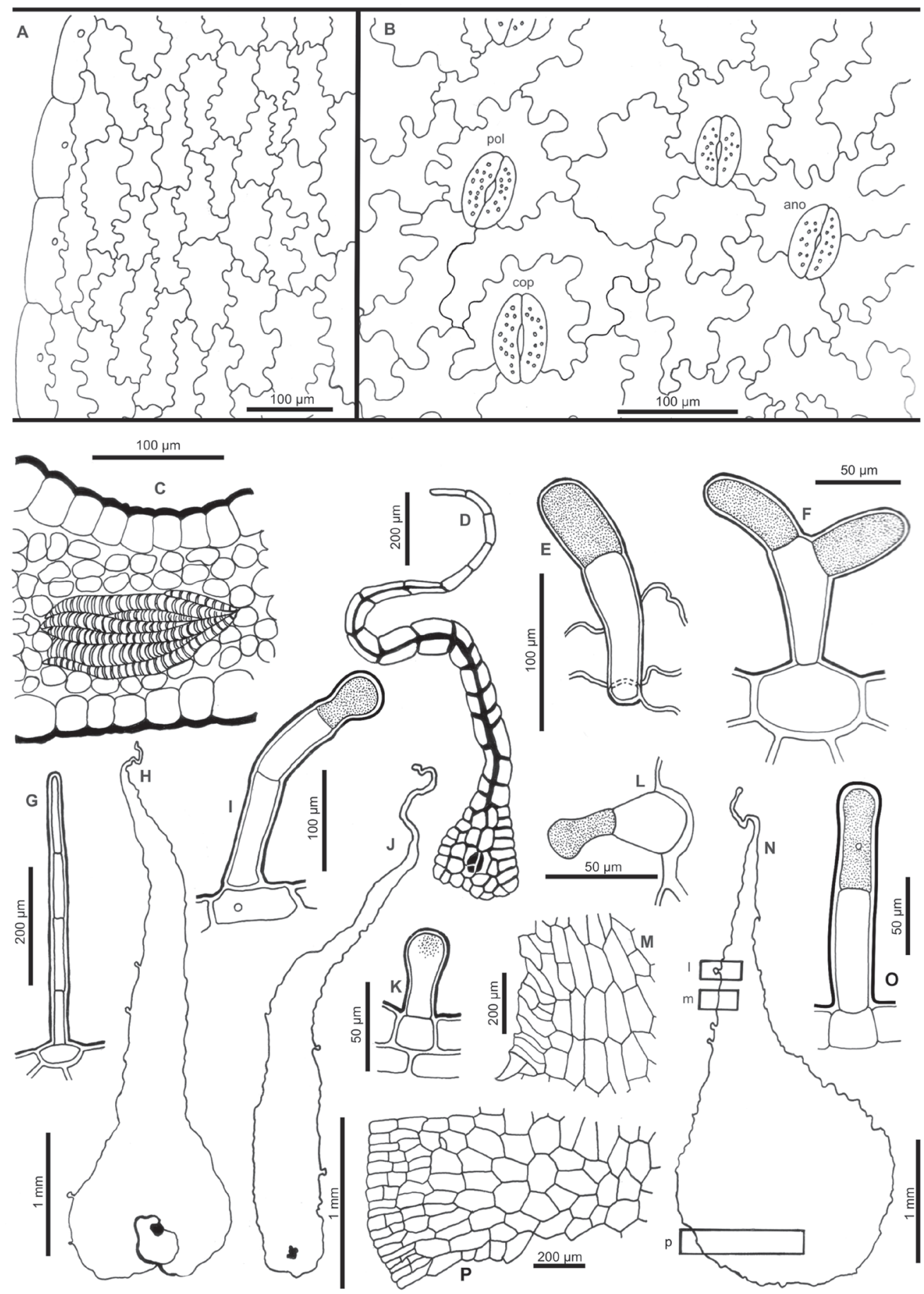

Figura 15. Serpocaulon gilliesii (Morero 273). A. Epifilo. B. Hipofilo con estomas polocíticos (pol), anomocíticos (ano) y copolocíticos (cop). C. Hidatodo en transcorte. D. Microescama del hipofilo. E, F, I, K, O. Pelos glandulares del hipofilo. L. Pelo glandular del margen de la escama, de sector indicado en N. G. Pelo eglandular uniseriado del hipofilo. H, J, N. Diferentes tipos de escamas rizomáticas. M, P. Detalles del reticulado celular de la escama rizomática, marcados en N.

Figure 15. Serpocaulon gilliesii (Morero 273). A. Upper epidermis. B. Lower epidermis with polocytic (pol), anomocytic (ano), and copolocytic (cop) stomata. C. Hydathode, cross section. D. Lower epidermis microscale. E, F, I, K, O. Lower epidermis glandular hairs. L. Margin scale glandular hair, shown in N. G. Lower epidermis non-glandular multicellular hair. H, J, N. Different types of rhizome scales. M, P. Rhizome scale cellular net in detail, shown in N. 


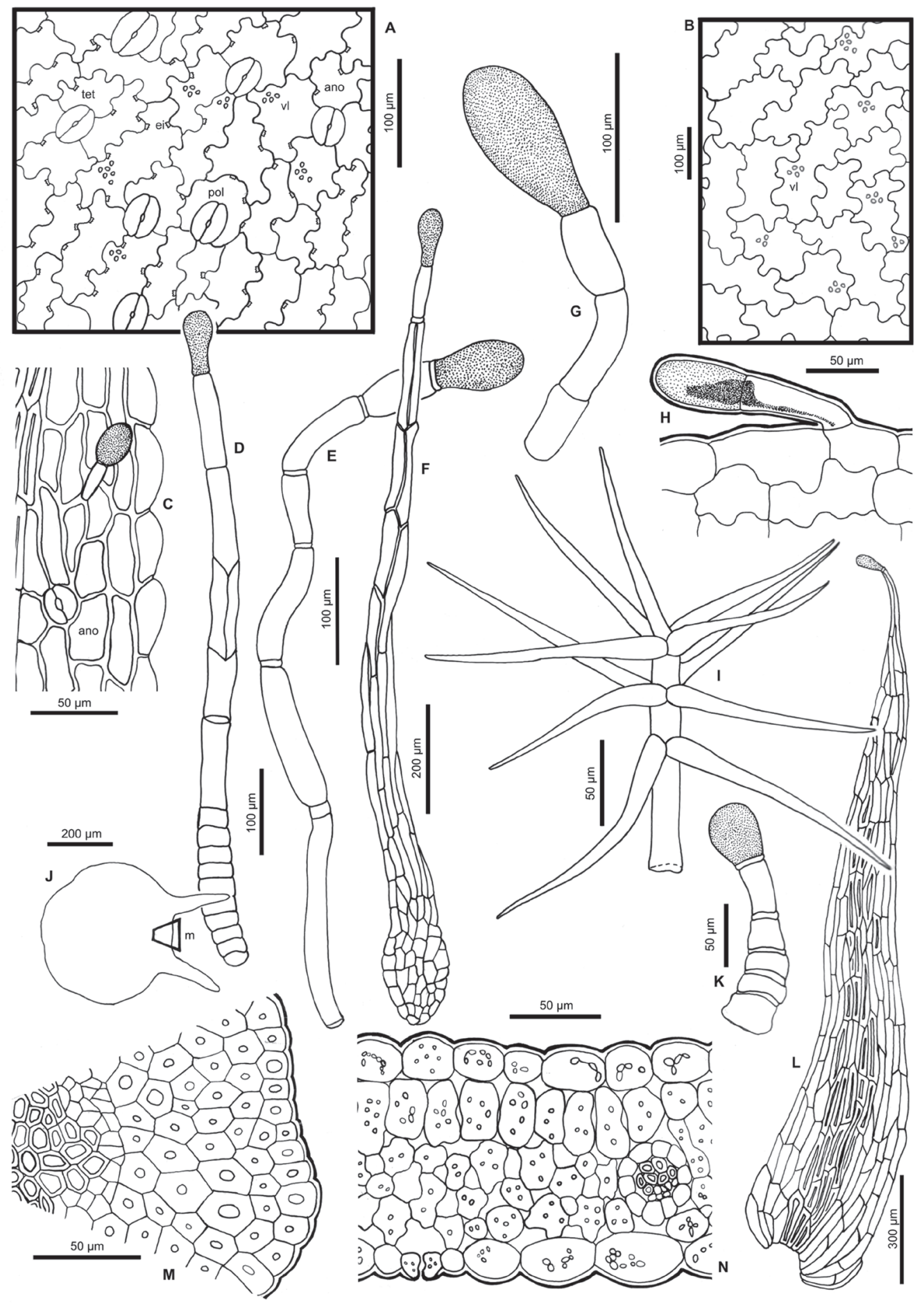

Figura 16. Adiantopsis chlorophylla (Morero 41). A. Hipofilo con estomas tetracíticos (tet), polocíticos (pol) y anomocíticos (ano); engrosamientos irregulares (ei) de la pared celular y vesículas lipídicas (vl). B. Epifilo. C. Raquis, sector del ala lateral, con estoma anomocítico (ano) y pelo glandular. D, F, G, K. Estadios transicionales de una escama rizomática. E. Pelo catenulado, del raquis. H. Pelo glandular, del hipofilo. I. Pelo dendroide de la lámina. J. Raquis, mostrando las expansiones laterales, en transcorte. L. Escama rizomática. M. Sector de raquis de zona indicada en J. N. Corte transversal de pínnula.

Figure 16. Adiantopsis chlorophylla (Morero 41). A. Lower epidermis with tetracytic (tet), polocytic (pol), and anomocytic (ano) stomata; irregular thickenings (ei) and lipid vesicles (vl) of the cell wall. B. Upper epidermis. C. Rachis wing sector, with anomocytic (ano) stoma and glandular hair. D, F, G, K. Transitional stages of a rhizome scale. E. Rachis catenate hair. H. Lower epidermis glandular hair. I. Leaf dendroid hair. J. Rachis showing lateral wings, cross section. L. Rhizome scale. M. Sector of rachis shown in J. N. Pinnule, cross section. 

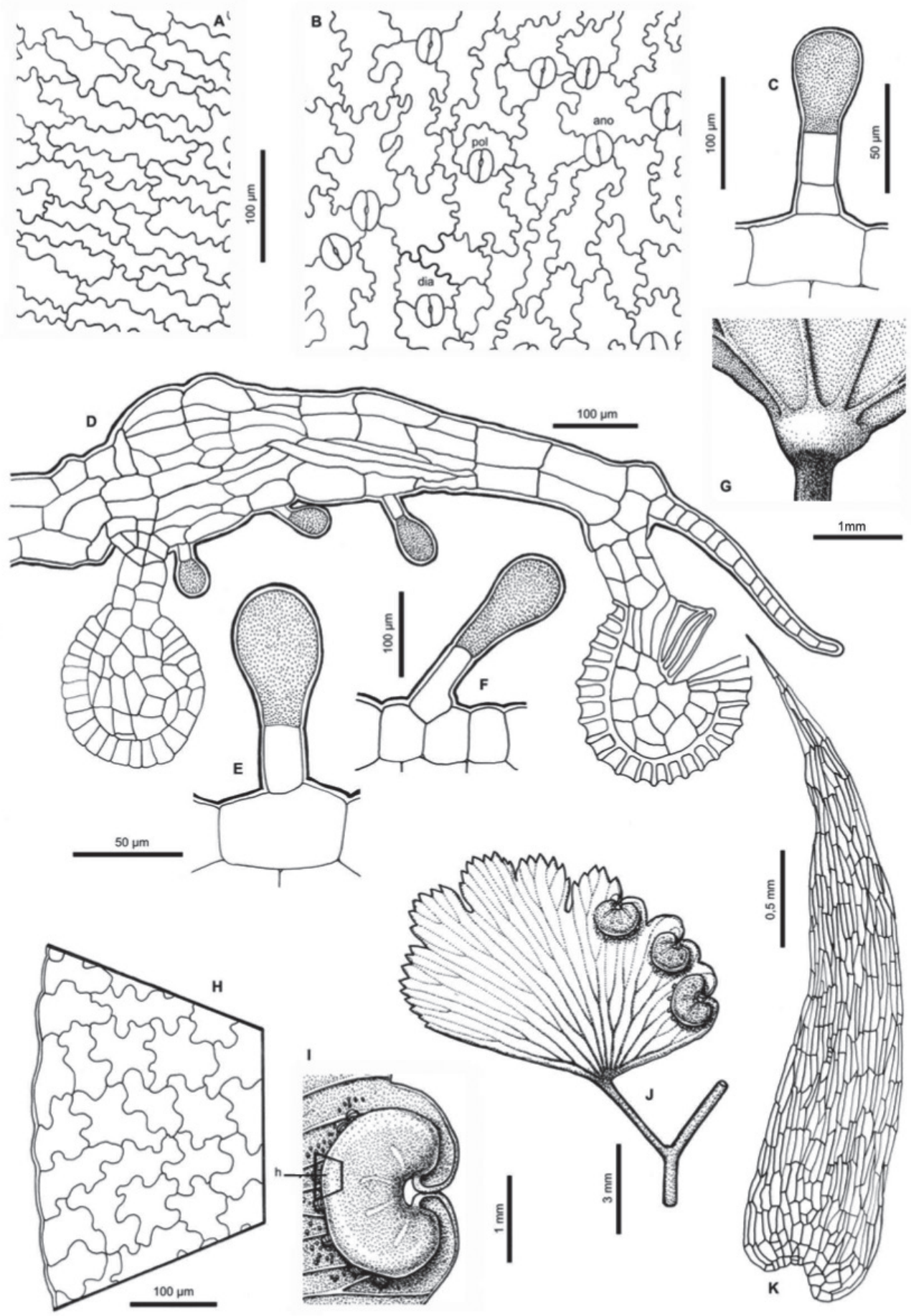

Figura 17. Adiantum orbygnianum (Morero 83). A. Epifilo. B. Hipofilo con estomas polocíticos (pol), anomocíticos (ano) y diacíticos (dia). C. Pelo glandular de la base de la pínnula. D. Pseudoindusio, en transcorte (obsérvese la disposición de los pelos glandulares y esporangios). E, F. Pelos glandulares del pseudoindusio. G. Base de una pínnula, mostrando la articulación con el peciolulo. H. Epidermis superior del pseudoindusio según se indica en I. I. Pseudoindusio en vista superficial. J. Envés de la pínnula, con tres pseudoindusios. K. Escama rizomática.

Figure 17. Adiantum orbygnianum (Morero 83). A. Upper epidermis. B. Lower epidermis with polocytic (pol), anomocytic (ano), and diacytic (dia) stomata. C. Glandular hair from the pinnule base. D. Pseudoindusium in cross section (observe the arrangement of the glandular hairs and sporangia). E, F. Pseudoindusium glandular hairs. G. Petiole base showing the petiolule joint. H. Pseudoindusium upper epidermis shown in I. I. Pseudoindusium in surface view. J. Pinnule abaxial surface with three pseudoindusia. K. Rhizome scale. 


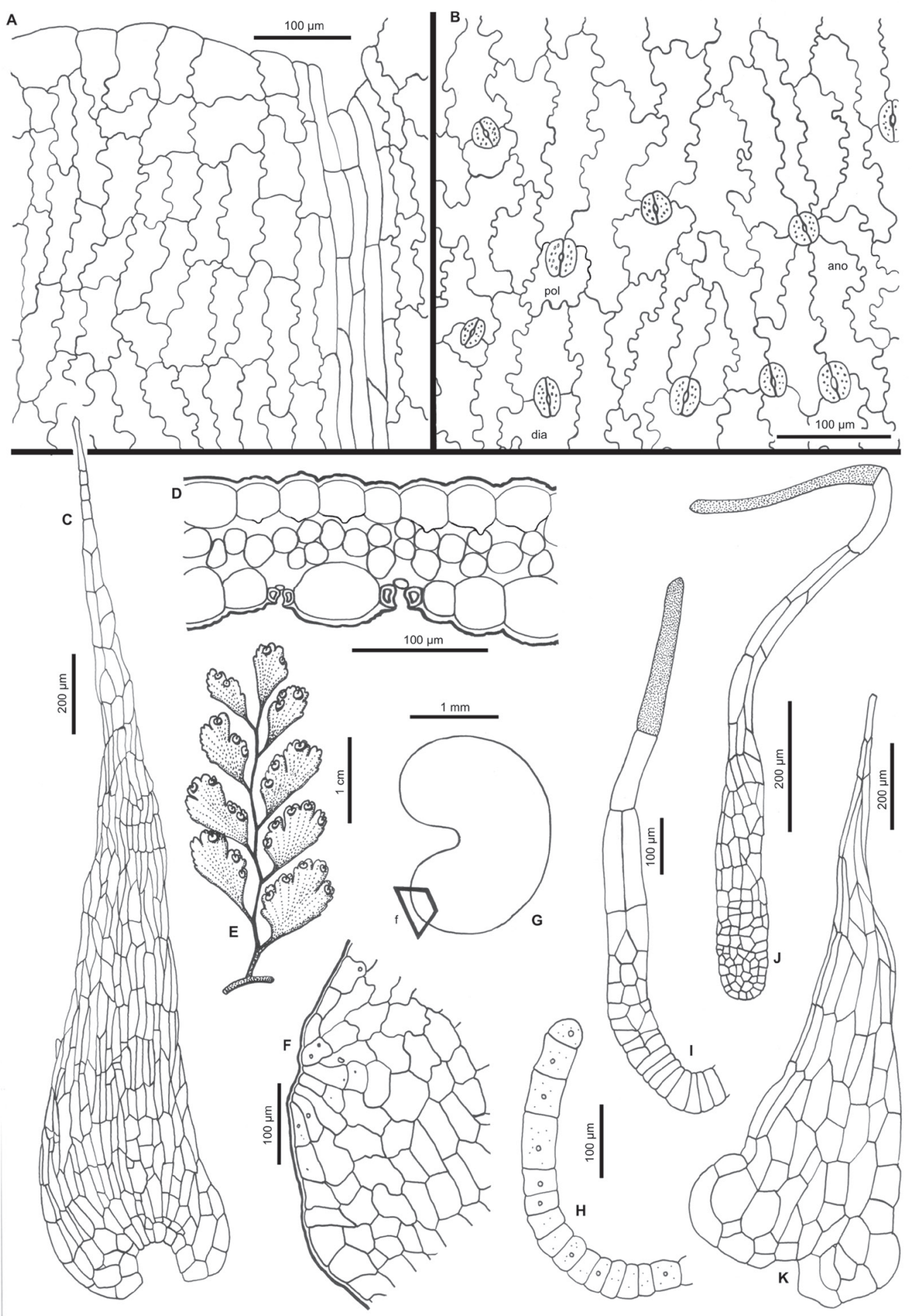

Figura 18. Adiantum raddianum (Morero 51). A. Epifilo. B. Hipofilo con estomas diacíticos (dia), anomocíticos (ano) y polocíticos (pol). C. Escama rizomática. D. Pínnula en transcorte (note las proyecciones de la pared tangencial interna de la epidermis superior). E. Pinna. F. Epidermis del pseudoindusio, del sector indicado en G. G. Contorno del pseudoindusio. H-K. Estadios transicionales de escamas jóvenes.

Figure 18. Adiantum raddianum (Morero 51). A. Upper epidermis. B. Lower epidermis with diacytic (dia), anomocytic (ano), and polocytic (pol) stomata. C. Rhizome scale. D. Pinnule in cross section (note the internal tangential wall projections of the upper epidermis). E. Pinna. F. Pseudoindusium epidermis shown in G. G. Pseudoindusium outline. H-K. Transitional stages of young scales. 


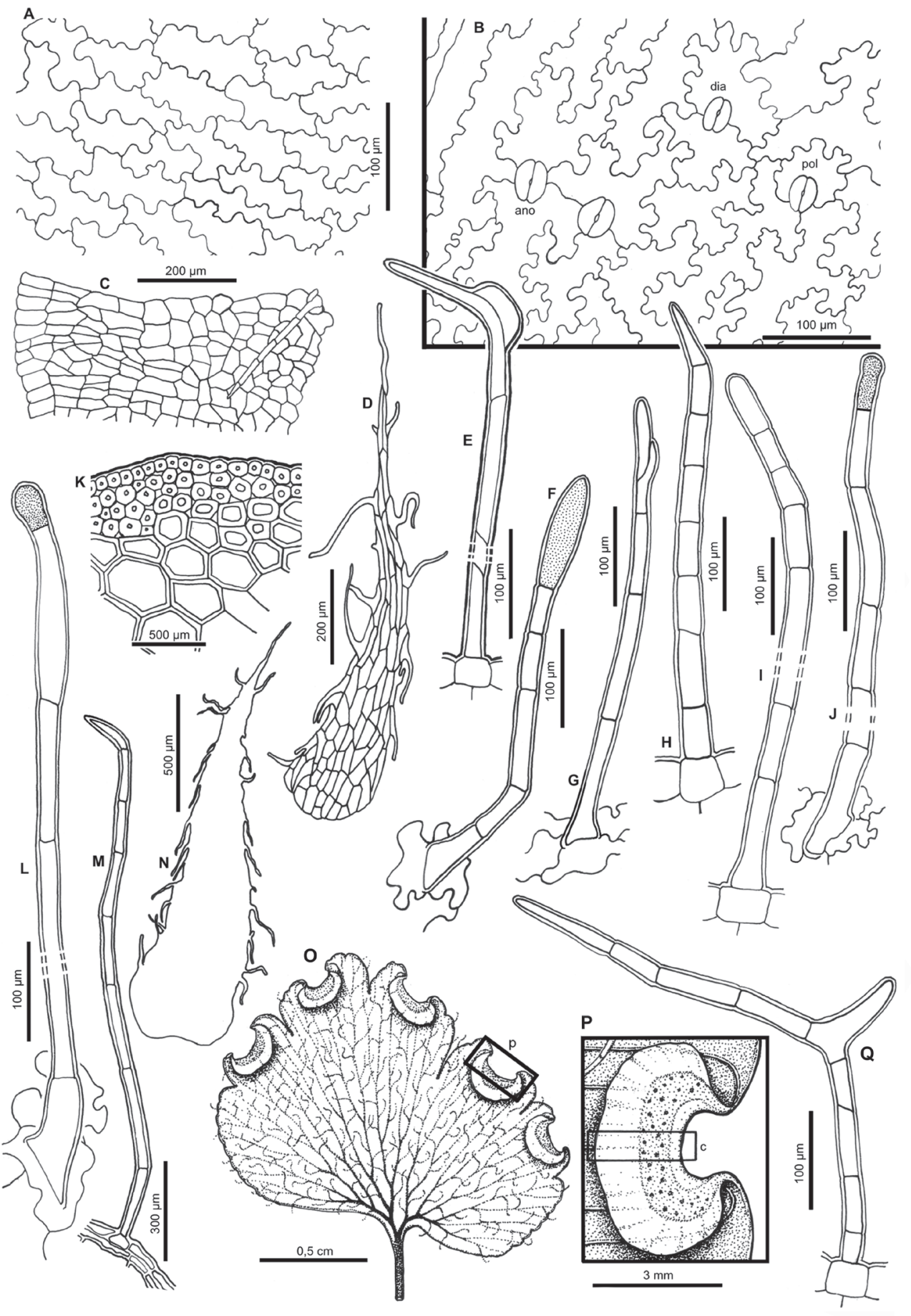

Figura 19. A, B, D, N. Adiantum thalictroides var. thalictroides (Morero 286). C, E, F-M, O-Q. Adiantum thalictroides var. hirsutum (Hunziker 8805). A. Epifilo. B. Hipofilo con estomas polocíticos (pol), diacíticos (dia) y anomocíticos (ano). C. Epidermis del pseudoindusio de sector señalado en P. D, N. Escamas rizomáticas ciliadas (D: entramado celular). E, G, Q. Pelos eglandulares ramificados. F, J, L. Pelos glandulares. H, I, M. Pelos eglandulares. K. Pecíolo en transcorte. O. Vista inferior de una pínnula. P. Detalle del pseudoindusio indicado en $\mathrm{O}$.

Figure 19. A, B, D, N. Adiantum thalictroides var. thalictroides (Morero 286). C, E, F-M, O-Q. Adiantum thalictroides var. hirsutum (Hunziker 8805). A. Upper epidermis. B. Lower epidermis with polocytic (pol), diacytic (dia), and anomocytic (ano) stomata. C. Pseudoindusium epidermis of the sector shown in P. D, N. Rhizome ciliate scales (D: cellular net). E, G, Q. Branched non-glandular hairs. F, J, L. Glandular hairs. H, I, M. Non-glandular hairs. K. Petiole, cross section. O. Pinnule abaxial surface. P. Pseudoindusium in detail shown in $\mathrm{O}$. 

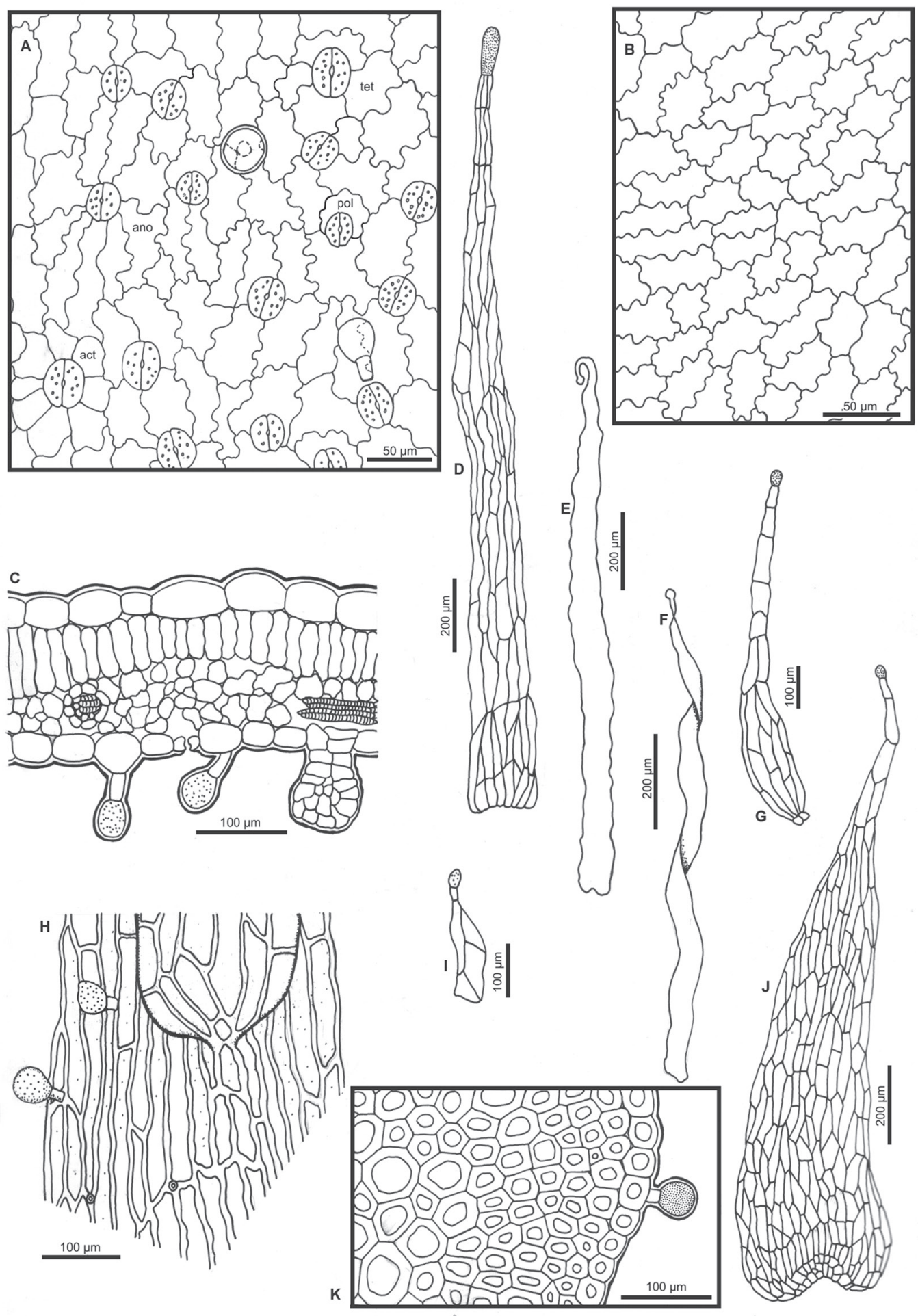

Figura 20. Argyrochosma nivea var. nivea (Morero 11). A. Hipofilo con estomas anomocíticos (ano), tetracíticos (tet), polocíticos (pol) y actinocíticos (act). B. Epifilo. C. Transcorte foliar (obsérvese un esporangio joven y pelos glandulares). D-F, J. Escamas del rizoma (D, J: entramado celular). G, I. Escamas rizomáticas jóvenes. H. Pelos glandulares y base de una escama de epidermis peciolar. K. Sector del pecíolo en transcorte.

Figure 20. Argyrochosma nivea var. nivea (Morero 11). A. Lower epidermis with anomocytic (ano), tetracytic (tet), polocytic (pol), and actinocytic (act) stomata. B. Upper epidermis. C. Leaf in cross section (observe young sporangium and glandular hairs). D-F, J. Rhizome scales (D, J: celular net). G, I. Young rhizome scales. H. Glandular hairs and scale base of petiole epidermis. K. Petiole sector, cross section. 


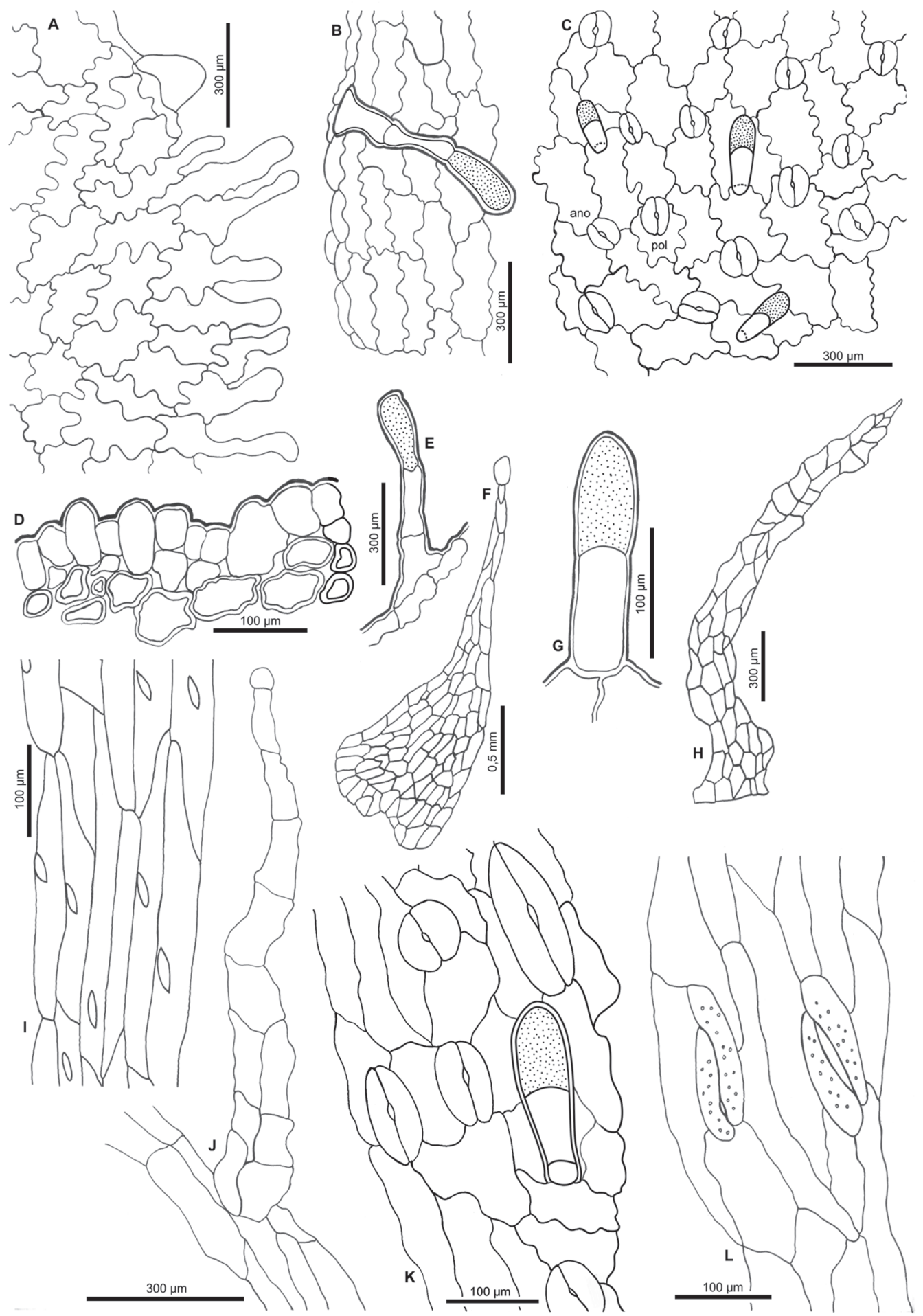

Figura 21. Cheilanthes marginata (Morero 151). A. Epidermis del pseudoindusio con margen fimbriado. B, E. Pelos glandulares de la lámina. C. Hipofilo con estomas polocíticos (pol) y anomocíticos (ano). D. Epidermis biestratificada de pecíolo en transcorte. F, H, J. Escamas rizomáticas (F, J: extremo globoso, H: extremo agudo). G. Pelo glandular foliar. I. Epidermis de pecíolo (células con núcleos ahusados). K, L. Epidermis del raquis con diferentes formas y tamaños de los estomas (L: estomas irregulares).

Figure 21. Cheilanthes marginata (Morero 151). A. Pseudoindusium epidermis with fimbriate margin. B, E. Leaf glandular hairs. C. Lower epidermis with polocytic (pol) and anomocytic (ano) stomata. D. Petiole biseriate epidermis, cross section. F, H, J. Rhizome scales (F, J: globose apex, H: acute apex). G. Leaf glandular hair. I. Petiole epidermis (cells with fusiform nuclei). K, L. Rachis epidermis with different stomata shapes and sizes (L: irregular stoma). 


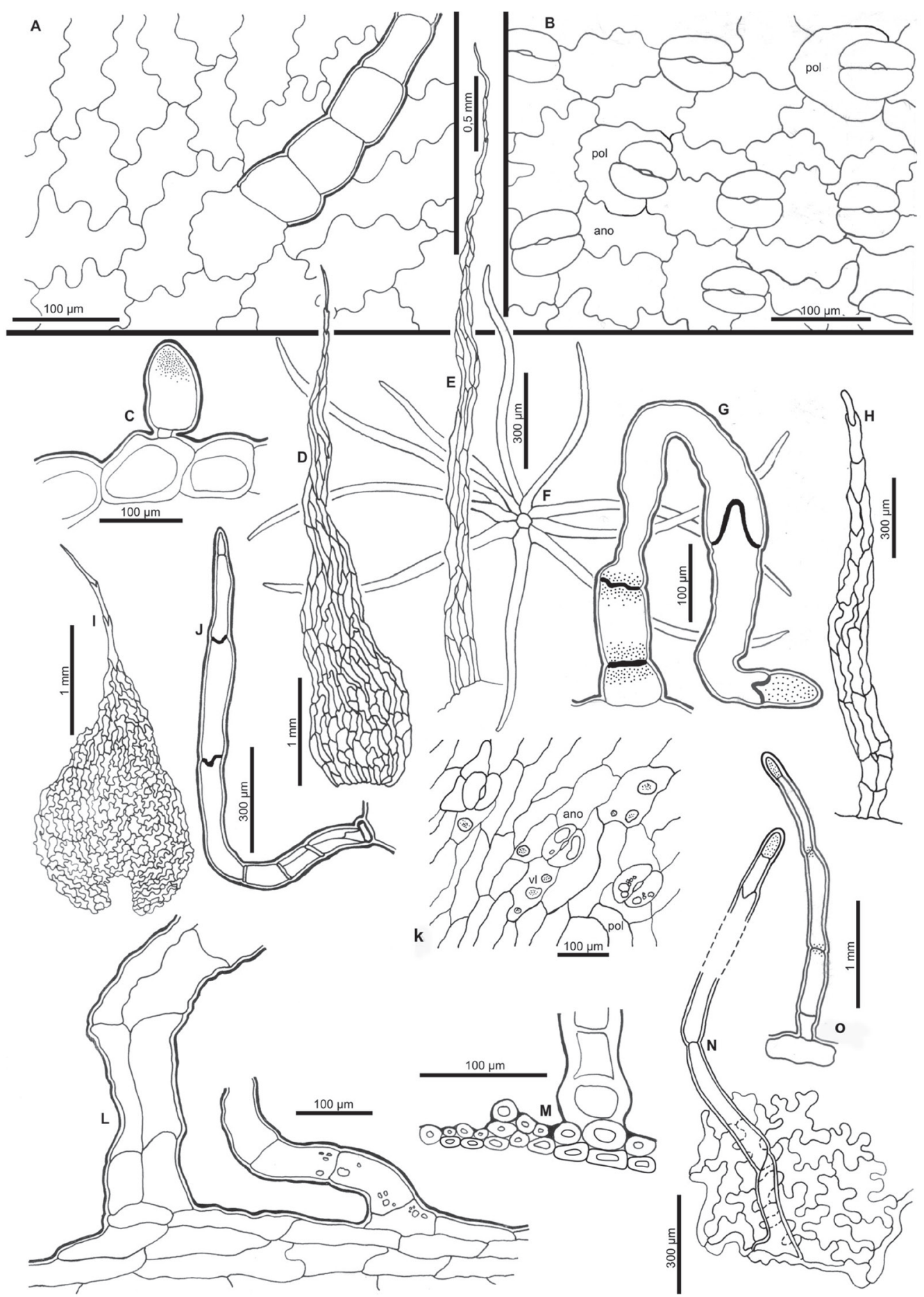

Figura 22. Cheilanthes myriophylla (Luján 108). A. Epifilo con base de un pelo pluricelular. B. Hipofilo con estomas anomocíticos (ano) y polocíticos (pol). C. Pelo glandular de la lámina. D, E, H, J. Escamas del rizoma y pecíolo. F. Pelo estrellado del rizoma. G. Pelo escamoso glandular del epifilo. I. Escama del raquis. K. Epidermis del raquis, con estomas y vesículas lipídicas (vl). L. Base de escama y pelo del raquis. M. Epidermis lignificada y base de un pelo del pecíolo. N, O. Pelos pluricelulares del pseudoindusio y pecíolo, respectivamente.

Figure 22. Cheilanthes myriophylla (Luján 108). A. Upper epidermis with multicellular hair base. B. Lower epidermis with anomocytic (ano) and polocytic (pol) stomata. C. Lamina glandular hair. D, E, H, J. Rhizome and petiole scales. F. Rhizome stellate hair. G. Upper scaly epidermis glandular hair. I. Rachis scale. K. Rachis epidermis with stomata and lipid vesicles (vl). L. Rachis scale and hair basis. M. Petiole lignified epidermis and hair base. N, O. Pseudoindusium and petiole multicellular hairs, respectively. 


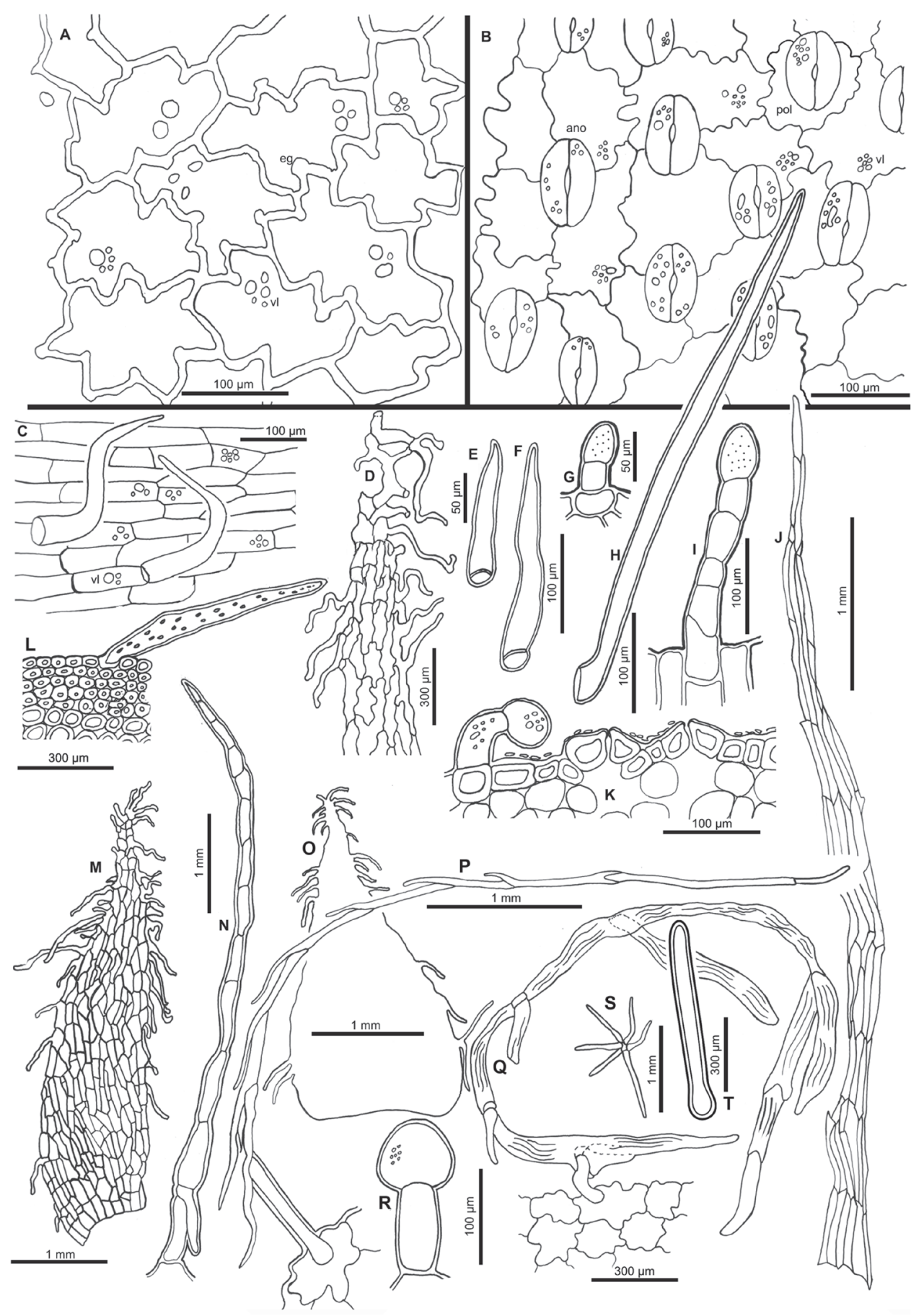

Figura 23. Cheilanthes obducta (Morero 59). A. Epifilo, células con paredes angulosas, engrosamientos celulósicos (eg) y vesículas lipídicas (vl). B. Hipofilo con estomas anomocíticos (ano), polocíticos (pol) y vesículas lipídicas. C, E, F, H. Pelos eglandulares del raquis. D, M, O. Escamas rizomáticas (en D sólo la zona apical). G, I. Pelos glandulares. J. Escama del pecíolo. K. Hipofilo con estomas elevados y pelo glandular. L. Epidermis esclerenquimatosa y pelo eglandular de pecíolo, en transcorte. N. Pelo ramificado del pecíolo. P, Q. Pelos ramificados del hipofilo y epifilo, respect. R. Pelo glandular del hipofilo. S. Pelo estrellado del rizoma. T. Pelo unicelular del rizoma.

Figure 23. Cheilanthes obducta (Morero 59). A. Upper epidermis, angulose cell walls, celullosic thickenings (eg), and lipid vesicles (vl). B. Lower epidermis with anomocytic (ano), polocytic (pol) stomata, and lipid vesicles (vl). C, E, F, H. Rachis non-glandular hairs. D, M, O. Rhizome scales (D scale apex in detail). G, I. Glandular hairs. J. Petiole scale. K. Lower epidermis with stomata raised above epidermis and glandular hair. L. Petiole sclerified epidermis and non-glandular hair, cross section. N. Petiole branched hair. P, Q. Lower epidermis and upper epidermis branched hairs, respectively. R. Lower epidermis glandular hair. S. Rhizome stellate hair. T. Rhizome unicellular hair. 


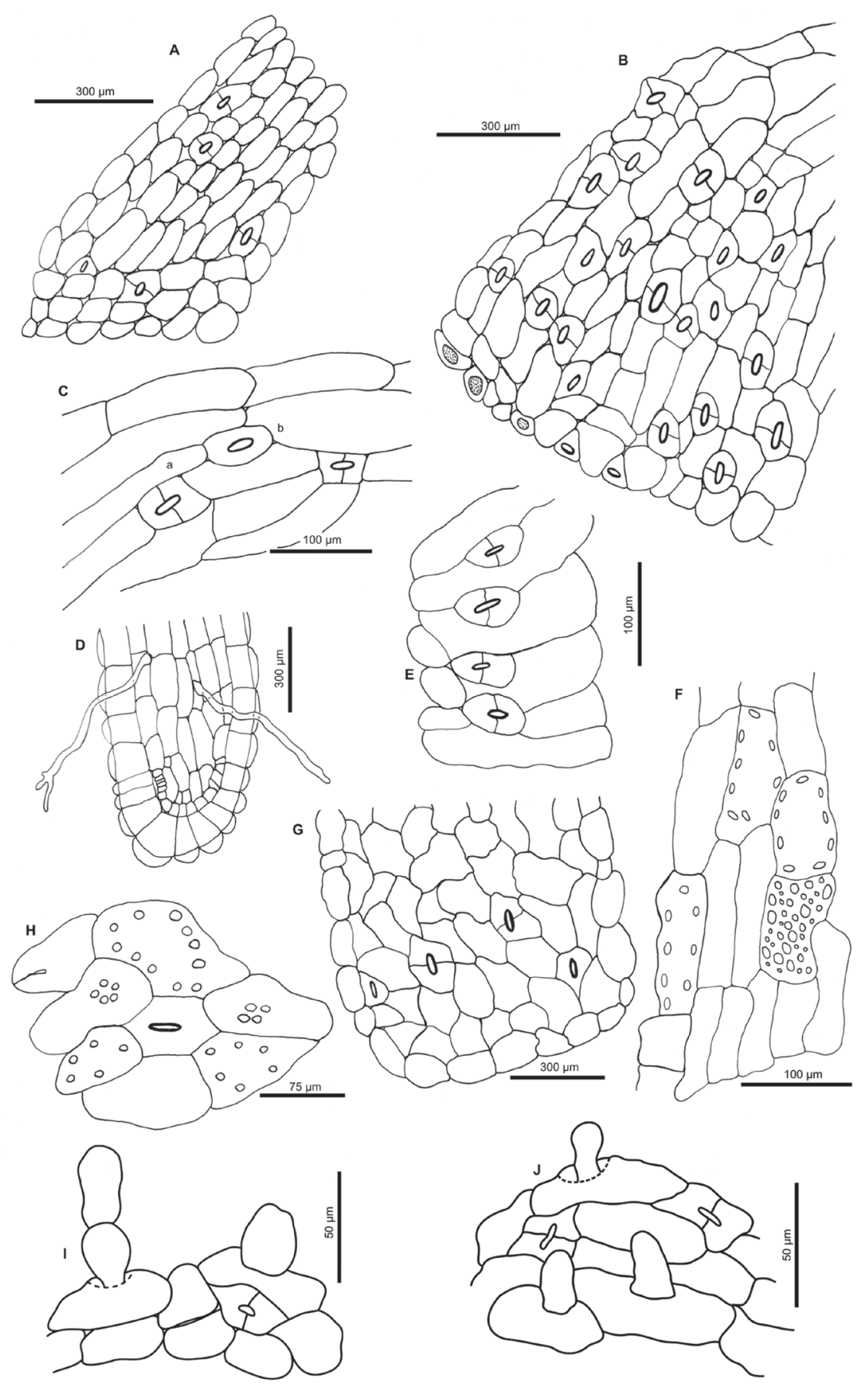

Figura 24. A-H. Azolla filiculoides (Morero 287). I-J. Azolla cristata (Di Fulvio 520). A. Epifilo del lóbulo emergente. B. Hipofilo del lóbulo emergente (note las células oclusivas transversales al ostíolo). C. Hipofilo de la zona comisural (a: células oclusivas perpendicular al poro; b: estoma en anillo). D. Raíz joven, vista paradermal. E. Estomas compartiendo células epidérmicas. F. Epidermis de la zona de unión de los lóbulos. G. Epifilo del margen del lóbulo sumergido. H. Estoma en forma de anillo. I. Epifilo del lóbulo emergente, con papilas uni-bicelulares. J. Epifilo del lóbulo sumergido, con papilas unicelulares.

Figure 24. A-H. Azolla filiculoides (Morero 287). I-J. Azolla cristata (Di Fulvio 520). A. Floating lobe upper epidermis. B. Floating lobe lower epidermis (note guard cells in transverse position to the pore). C. Notch lower epidermis (a: guard cells in transverse position to the pore; b: ring stoma). D. Young root, surface view. E. Stomata sharing epidermal cells. F. Epidermis of the junction of the lobes. G. Upper epidermis of submersed lobe margin. H. Ring stoma. I. Upper epidermis of floating lobe showing uni-bi-cellular papillae. J. Upper epidermis of the submersed loble showing unicellular papillae. 


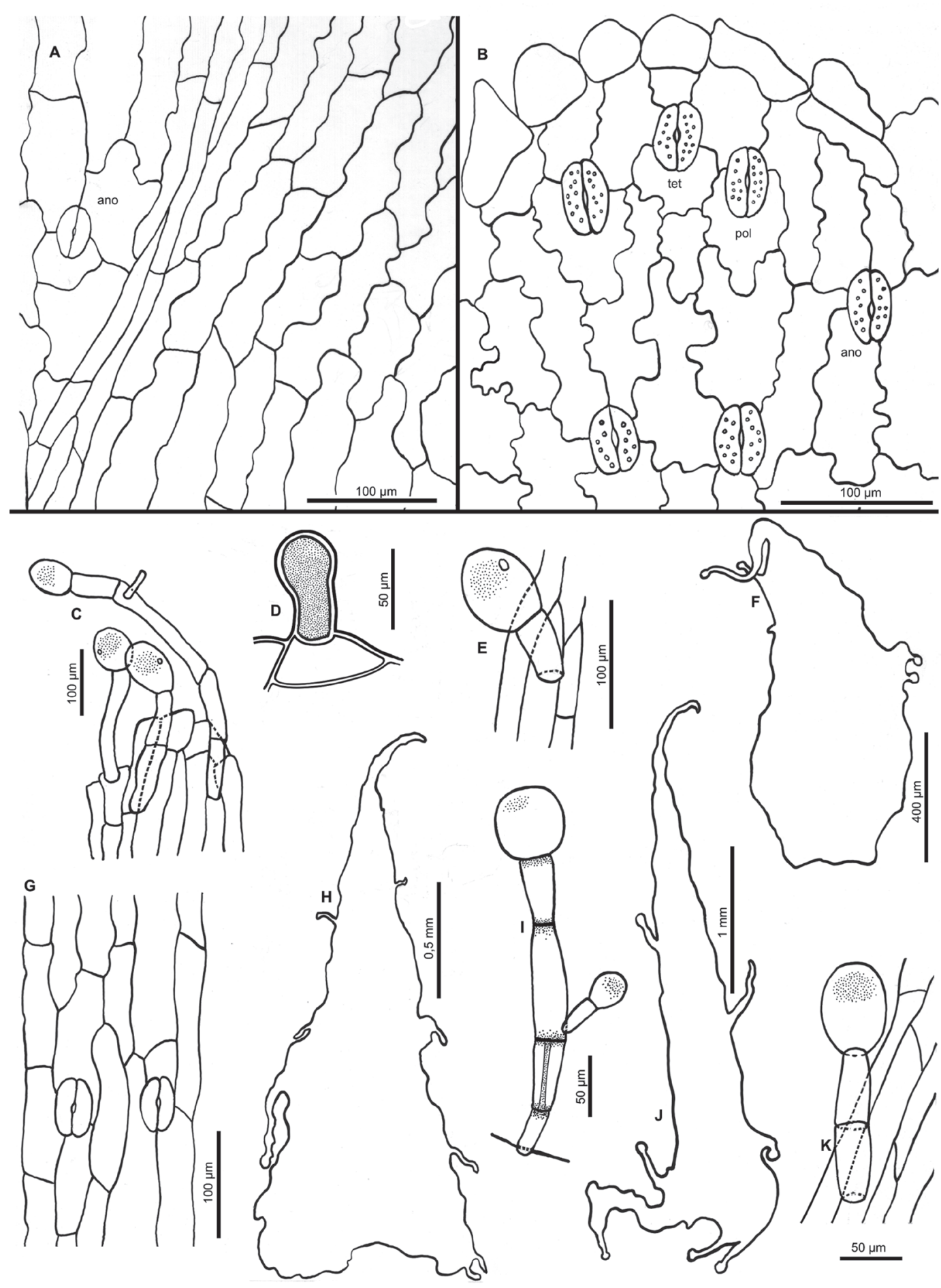

Figura 25. Cystopteris fragilis (Morero 172). A. Epifilo con estoma anomocítico (ano). B. Hipofilo con estomas polocíticos (pol), tetracíticos (tet) y anomocíticos (ano). C. Pelos glandulares del margen de la escama peciolar. D. Pelo glandular del raquis. E, K. Pelos glandulares del pecíolo. F, J. Escamas del pecíolo. G. Epidermis del pecíolo con estomas anomocíticos. H. Escama rizomática. I. Pelo ramificado del raquis.

Figure 25. Cystopteris fragilis (Morero 172). A. Upper epidermis with anomocytic stoma (ano). B. Lower epidermis with polocytic (pol), tetracytic (tet), and anomocytic (ano) stomata. C. Petiole scale margin with glandular hairs. D. Rachis glandular hair. E, K. Petiole glandular hairs. F, J. Petiole scales. G. Petiole epidermis with anomocytic stomata. H. Rhizome scale. I. Rachis branched hair. 

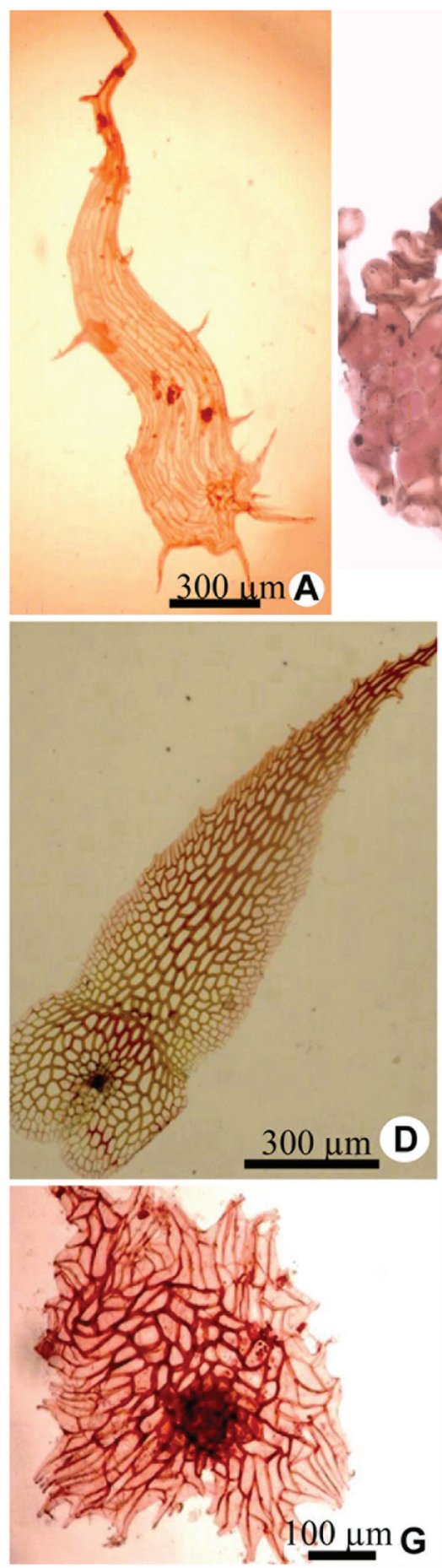
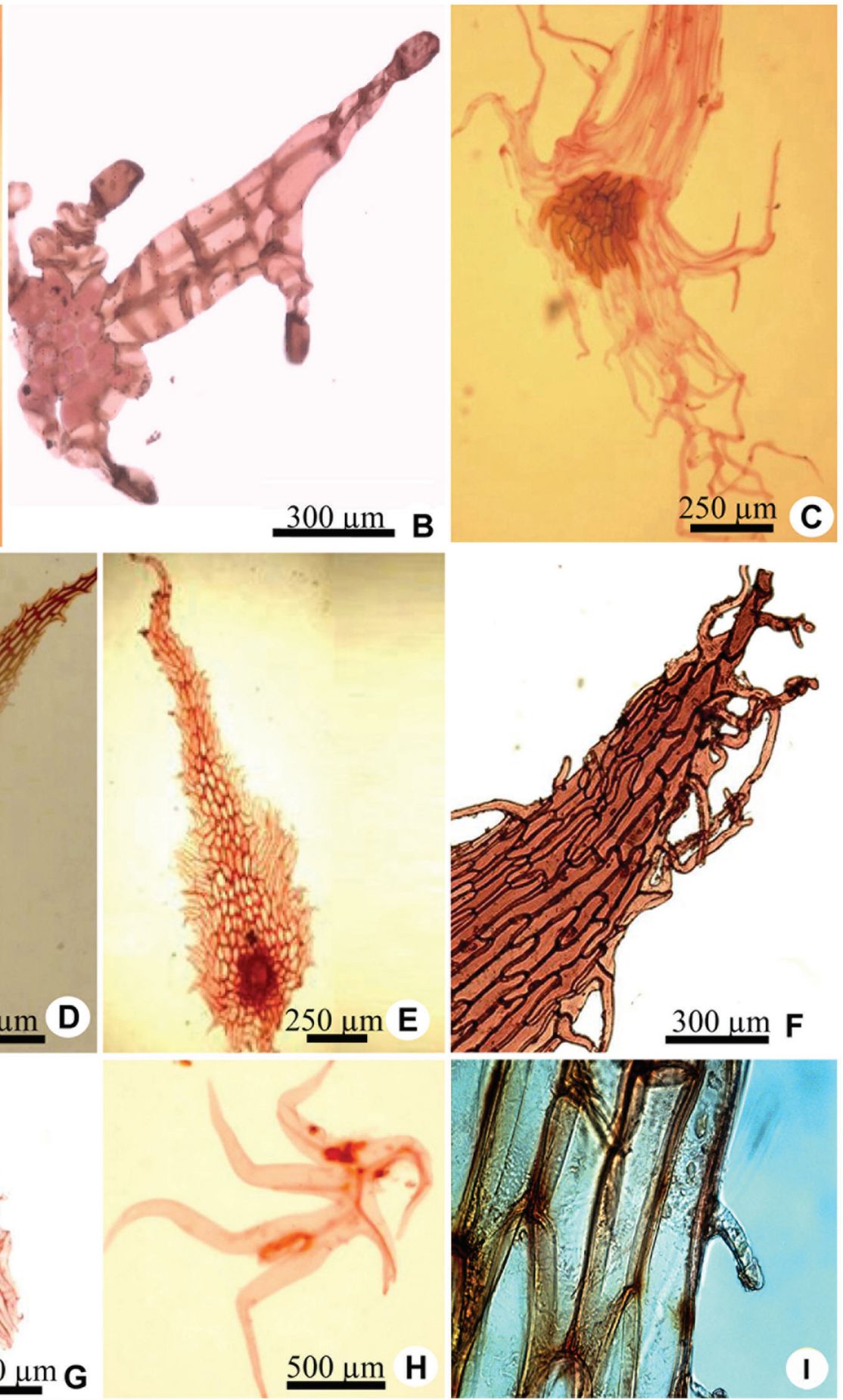

Figura 26. Escamas y microescamas de helechos. A, H. Blechnum cordatum (Morero 161), escama y microescama foliar, respect. B. Elaphoglossum gayanum (Barboza 783), escama foliar. C. Nephrolepis cordifolia (Luján 107), base de una escama del pecíolo. D, G. Pleopeltis pinnatifida (Morero 133), escama rizomática y foliar, respect. E. Serpocaulon gilliesii (Morero 273), escama rizomática. F. Cheilanthes obducta (Morero 97), sector de una escama rizomática. I. Cystopteris fragilis (Morero 172), detalle de escama rizomática.

Figure 26. Scales and microscales in ferns. A, H. Blechnum cordatum (Morero 161), Leaf scale and microscale, respectively B. Elaphoglossum gayanum (Barboza 783), leaf scale. C. Nephrolepis cordifolia (Luján 107), petiole scale base. D, G. Pleopeltis pinnatifida (Morero 133), rhizome and leaf scales, respectively. E. Serpocaulon gilliesii (Morero 273), rhizome scale. F. Cheilanthes obducta (Morero 97), sector of rhizome scale. I. Cystopteris fragilis (Morero 172), rhizome scale in detail. 

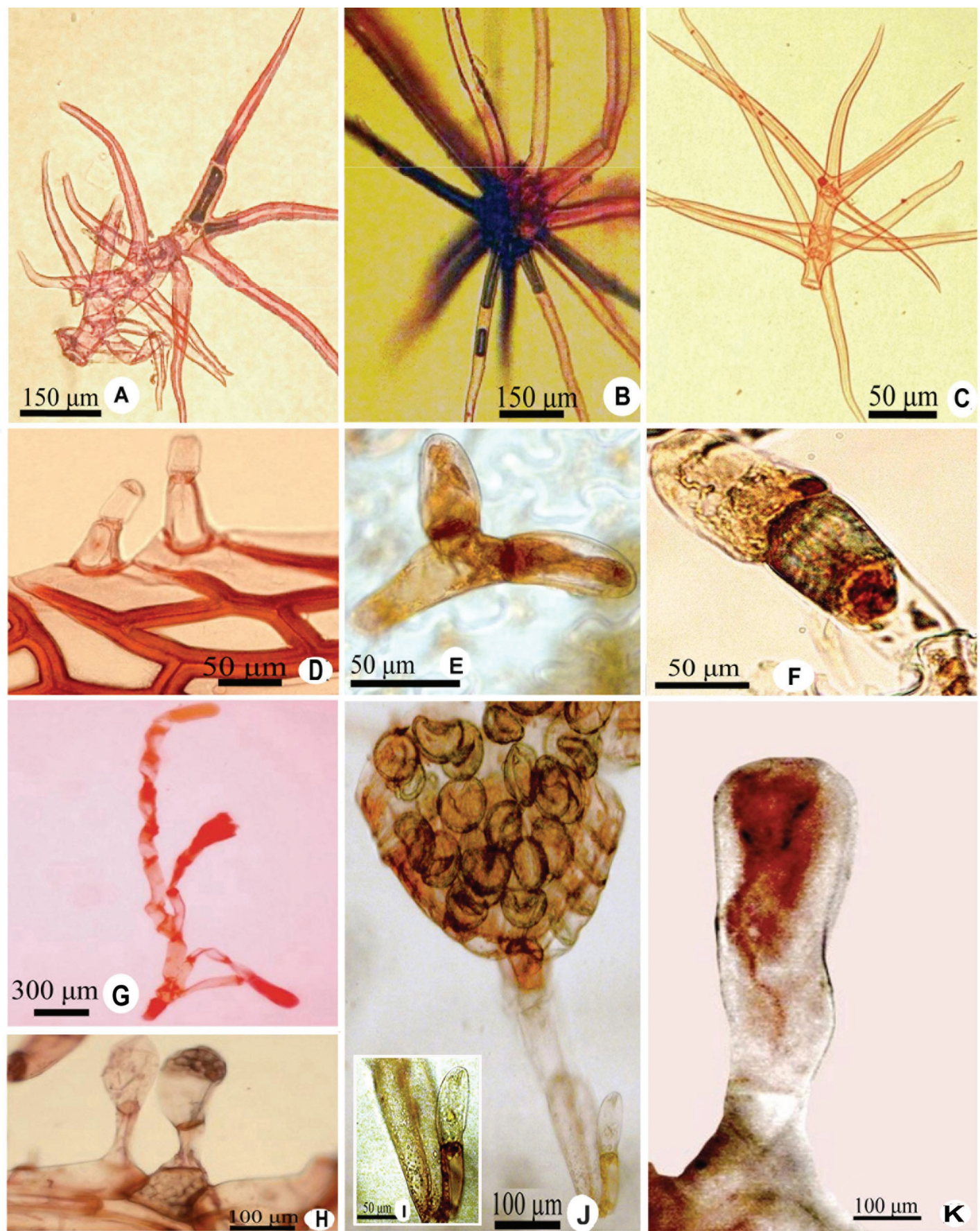

Figura 27. Pelos de helechos. A. Equisetum bogotense (Zavala 3894), pelo dendroide del tallo aéreo. B. Cheilanthes marginata (Morero 151), pelo estrellado del rizoma. C. Adiantopsis chlorophylla (Morero 41), pelo dendroide de la lámina. D, E, I, J. Serpocaulon gilliesii (Morero 273), D. Pelos del margen de la escama rizomática. E. Pelo bifurcado del hipofilo. J. Pelo glandular del pie del esporangio. I. Detalle del pelo mostrado en J. F, H. Blechnum hastatum (Morero 143), F. Pelo del hipofilo. H. Pelos del margen de escama peciolar. G. Nephrolepis cordifolia (Luján 119), pelo ramificado del hipofilo. K. Adiantum orbignyanum (Morero 83), pelo glandular de la base de la pínnula.

Figure 27. Hairs of ferns. A. Equisetum bogotense (Zavala 3894), aerial stem dendroid hair. B. Cheilanthes marginata (Morero 151), rhizome stellate hair. C. Adiantopsis chlorophylla (Morero 41), lamina dendroid hair. D, E, I, J. Serpocaulon gilliesii (Morero 273 ), D. Hairs of rhizome scale margin. E. Lower epidermis forked hair. J. Glandular hair on sporangium stalk. I. Detail hair showed in J. F, H. Blechnum hastatum (Morero 143), F. Lower epidermis hair. H. Scale margin hairs. G. Nephrolepis cordifolia (Luján 119), lower epidermis branched hair. K. Adiantum orbignyanum (Morero 83), glandular hair of the pinnule base. 

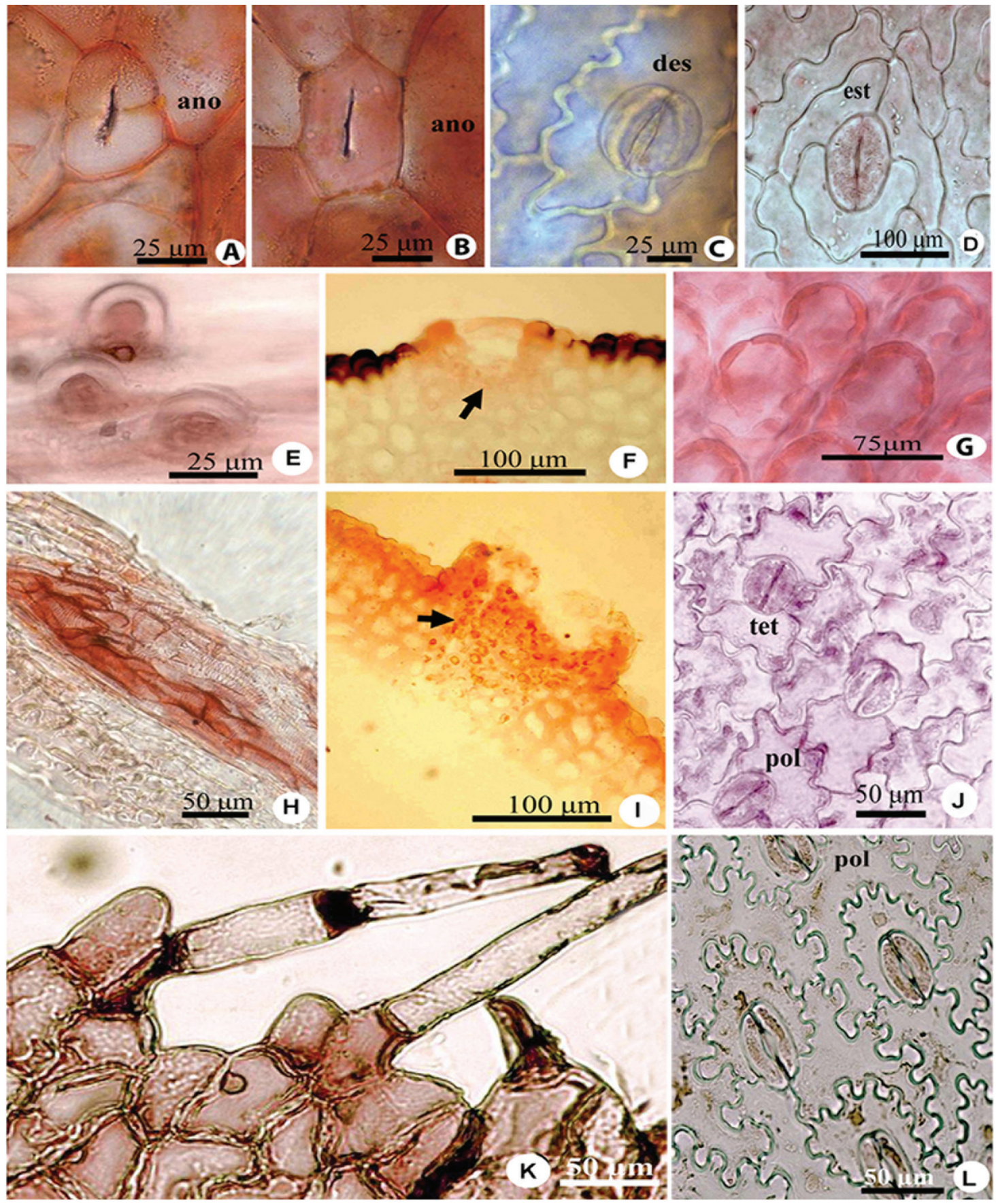

Figura 28. Papilas y estructuras de ventilación. A, B, G. Azolla filiculoides (Morero 287), A, B. Estomas foliares anomocíticos (ano), joven y adulto respect. G. Papilas de la epidermis foliar. C. Anemia tomentosa var. tomentosa (Luján 118), estoma desmocítico (des). D. Nephrolepis cordifolia (Luján 107), estoma estaurocítico (est). E, K, L. Blechnum hastatum (Morero 143), E. Papilas del pecíolo. K. Margen del indusio papiloso-piloso. L. Estomas polocíticos (pol). F. Equisetum giganteum (Luján 40), lenticela del tallo aéreo. H, I. Blechnum cordatum (Morero 161), hidatodo y lenticela foliar respect. J. Pleopeltis pinnatifida (Morero 133), estoma tetracítico (tet) y polocítico (pol).

Figure 28. Papillae and respiratory structures. A, B, G. Azolla filiculoides (Morero 287), A, B. Leaf anomocytic stomata (ano), young and mature respectively. G. Papillae of leaf epidermis. C. Anemia tomentosa var. tomentosa (Luján 118), desmocytic stoma (des). D. Nephrolepis cordifolia (Luján 107), staurocytic stoma (est). E, K, L. Blechnum hastatum (Morero 143), E. Petiole papillae. K. Margin indusium papillate-pilose. L. Polocytic stomata (pol). F. Equisetum giganteum (Luján 40), aerial stem lenticel. H, I. Blechnum cordatum (Morero 161), leaf hydathode and lenticel, respectively. J. Pleopeltis pinnatifida (Morero 133), tetracytic (tet) and polocytic (pol) stomata. 


\section{Discusión}

Tricomas - A través de este estudio, se encontraron pelos y escamas novedosos o raros para la pteridología. Así, los pelos de aspecto escamoso observados en Cyptosteris fragilis, Adiantopsis chlorophylla y Nephrolepis cordifolia, cuya morfología es muy particular debido a la presencia de los engrosamientos y pigmentación de las paredes celulares, se describen por primera vez; igual situación ocurre para los pelos ramificados cónicos de Blechnum cordatum, Adianthum thalictroides var. hirsutum y para Cheilantes obducta, para las microescamas con paredes celulares anticlinales muy engrosadas de Serpocaulon gilliesii, y para las microescamas irregulares y peltadas de Blechnum cordatum y las lineares bicolores, con o sin ramificaciones laterales terminadas en una glándula, de Blechnum hastatum.

La presencia o ausencia y la variedad de pelos y escamas resultó significativa para diferenciar los taxones a distintas jerarquías taxonómicas. Así, en Pteridaceae, es frecuente la presencia de pelos glandulares y eglandulares (Giúdice 1999, Graçano et al. 2001, Chuang \& Liu 2003 ). La mayoría de las especies de Adiantum presentan pelos glandulares con cabeza globosa y sólo $A$. thalictroides var. hirsutum exhibe en el hipofilo diversos tipos de pelos eglandulares combinados con glandulares; son glabros Adiantum raddianum y $A$. thalictroides var. thalictroides. Con respecto a los pelos glandulares de A. orbygnianum, Giudice (1999) los restringe a los soros bajo el término parafisos; sin embargo, estos mismos pelos se han encontrado también en otras áreas de las pínnulas.

La excepcional diversidad morfológica del indumento es una característica de Cheilanthes (Tryon \& Tryon 1982), la que es evidente en las tres especies estudiadas: Cheilanthes obducta se destaca por presentar la mayor densidad y diversidad tricomática. Especial referencia merecen los pelos estrellados presentes en rizomas de Cheilanthes myriophylla, Cheilanthes obducta y Cheilanthes marginata que no habían sido citado en publicaciones anteriores como la de Hernández de Terán (1992). En estudios anatómicos de otras especies de Cheilanthes de México (Knobloch et al. 1975) y de Argentina (Ponce \& Morbelli 1989) tampoco se encuentran referencias a los pelos estrellados, pero sí se los han mencionado para algunas especies de Cheilanthes de Australia (Quirk et al. 1983, Chambers \& Farrant 1991). Por último, Adiantopsis chlorophylla se destaca y diferencia de las restantes especies de Pteridaceae estudiadas por los pelos ramificados de tipo dendroide.

En Polypodiaceae s.l., Ogura (1972) se refiere a la amplia variabilidad morfológica de los pelos, haciendo mención, entre otros tipos, a los ramificados; entre los representantes de la familia estudiados, se observó que Serpocaulon gilliesii presenta pelos glandulares ramificados. Estos mismos resultan similares en su morfología a los observados en gametófitos de Synammia feuillei (Bertero) Copel. var. feuillei (sub nom. Polypodium feuillei Bertero, Gabriel-y-Galán et al. 2008) y en el hipofilo del esporófito joven de Pleopeltis lepidopteris (Langsd. \& Fisch.) de la Sota (sub nom. Polypodium lepidopteris (Langsd. \& Fisch.) Kunze, cfr. Sota 1966).

En Blechnaceae, Blechnum hastatum es un taxón muy afín a Blechnum australe subsp. auriculatum; según Rolleri \& Prada (2006a) no es clara la delimitación de ambos taxones ya que algunos autores aducen criterios para separarlos (Sota $1972 \mathrm{a}, \mathrm{b}$ ) o, por el contrario, otros los consideran una única entidad (Murillo 1968, Durán 1997). En los ejemplares de Blechnum hastatum estudiados se halló una amplia variedad de pelos glandulares y eglandulares presentes en pinnas, ejes foliares, indusios y sobre las escamas peciolares y rizomáticas, además de microescamas en los raquis, datos que son novedosos para esta especie. Un carácter relevante es la conspicua pilosidad del indusio en Blechnum hastatum que es poco frecuente en Blechnum australe subsp. auriculatum (Sota1972 a, b, Sota et al. 1998). Si bien Rolleri (1976) y Durán (1997) afirman que la pilosidad no es por sí misma determinante debido a su variabilidad en este complejo de especies, el indumento de Blechnum australe subsp. auriculatum muestra algunas diferencias con el de Blechnum hastatum (Morero, obs. pers.), en cuanto a tipos de pelos y distribución en la planta. Por lo que esta información podría apoyar la aceptación de dos entidades independientes.

Con respecto a la presencia de papilas en la epidermis de las especies de Blechnum, se sugirió que este carácter es un rasgo propio del grupo Blechnum penna-marina (Rolleri \& Prada 2006b). Sin embargo, hemos observado que el pecíolo presenta papilas restringidas al surco medio en Blechnum cordatum y distribuidas uniformemente en todo el órgano en Blechnum hastatum; esta situación pone en evidencia que las papilas no son exclusivas del complejo Blechnum penna-marina.

Dentro de Dryopteridaceae, tanto Guantay \& Hernández-de-Terán (1995) como Lavalle \& 
Rodríguez (2010) diferencian anatómicamente a varias especies de Elaphoglossum incluyendo a Elaphoglossum gayanum. Estas autoras reportan para Elaphoglossum gayanum, epifilo glabro e hipofilo con algunas escamas. Sin embargo, en nuestras observaciones confirmamos la presencia de pelos unicelulares cónicos y acintados acompañados por una mayor variedad de escamas en la lámina.

Estomas- Helechos y licófitas muestran una gran variedad de estomas siendo Anemia tomentosa y Nephrolepis cordifolia las especies con mayor diversidad estomática. Algunos tipos de estomas resultan diagnósticos a nivel genérico. Tal es el caso de los paracítico-criptoporo de Equisetum (Fryns-Claessens \& Van Cotthem 1973, los pericíticos y desmocíticos de Anemia (Fryns-Claessens \& Van Cotthem 1973), los anomocíticos de Azolla, con las paredes contiguas de las células oclusivas perpendiculares al eje del poro (Di Fulvio 1956). Respecto a los estomas pericíticos de Anemia tomentosa var. anthriscifolia, Ribeiro et al. (2007) afirman que esta variedad sólo presenta estomas flotantes si bien también hemos observado estomas suspensa (desmocítico) en el hipofilo de los tres taxones de Anemia aquí analizados.

En Lycopodium, la presencia y ubicación de los estomas parece no ser constante a nivel específico. Así, Rolleri-de-Dougherty (1972) sostiene que los tallos de Lycopodium clavatum y Lycopodium thyoides poseen estomas que no han sido observados en los ejemplares aquí examinados. De igual manera, la lámina de Lycopodium thyoides puede ser hipostomática (Rolleri-de-Dougherthy 1972) o anfistomática (este trabajo).

Asplenium monanthes presenta cuatro tipos de estomas: anomocíticos, polocíticos, copolocíticos y algunos pocos diacíticos; los dos primeros se encuentran también en el grupo de "Asplenium squamosum" de América descriptos por Ganem et al. (2007), en tanto que los últimos son novedosos para esta especie.

Durán (1997), en su revisión del género Blechnum para Argentina, observó sólo estomas anomocíticos en todos los taxones y, dada la uniformidad de este carácter, desestimó su valor diagnóstico. Sin embargo, y coincidiendo con Van Cotthem (1973), hemos observado, además, estomas polocíticos y copolocíticos en Blechnum cordatum y Blechnum hastatum. Por otro lado, en el grupo Blechnum penna-marina, Rolleri \& Prada (2006b) reporta también estomas anisocíticos y diacíticos.
Contrariamente a las opiniones de Rolleri \& Prada (2006b) coincidentes con Durán (1997), estimamos que este carácter debería reconsiderarse como valor diagnóstico para la delimitación de especies o grupos de especies dentro del género.

Las Pteridáceas estudiadas presentaron con mayor frecuencia estomas anomocíticos y polocíticos comunes en la familia (Van Cotthem 1973, Graçano et al. 2001), y en menor medida poseen estomas tetracíticos y, en algunos casos, copolocíticos. En las especies de Adiantum se observaron, además de los mencionados, el tipo diacítico, ya citado para otras especies del mismo género (Graçano et al. 2001). Asimismo, en Adiantum la posición de los estomas en relación a las células epidérmicas tiene valor taxonómico a nivel específico (Chuang \& Liu 2003); esto se evidenció en los cuatro taxones analizados ya que sólo tienen estomas levemente hundidos Adiantum orbygnianum y Adiantum raddianum en tanto que las dos variedades de Adiantum thalictroides los poseen a nivel.

En el género Adiantopsis, los estomas anomocíticos parecen ser lo más comunes (Link-Pérez \& James-Hickey 2011); sin embargo, Adiantopsis chlorophylla mostró los cuatro tipos de estomas típicos de la Pteridaceae.

Caracteres epidérmicos - Se mencionan por primera vez para las especies de Adiantum aquí estudiadas, la presencia de proyecciones unguladas, denominadas "armpalisade type" por Haberlandt (1882); este carácter ha sido descripto en otras especies de Adiantum por Wylie (1948) y Graçano et al. (2001).

En Córdoba (Argentina), habitan los tres taxones infraespecíficos de Argyrochosma nivea habiendo reportes de sólo dos de ellos como medicinales (Barboza et al. 2009). Su diferenciación se basa fundamentalmente en la presencia o ausencia y coloración de la farina (Tryon \& Tryon 1982, Sigel et al. 2011). Las variedades medicinales se distinguen especialmente por la coloración de la farina siendo blanca en Argyrochosma nivea var. nivea y amarilla en Argyrochosma nivea var. flava. Este carácter también tiene relevancia filogenética según Sigel et al. (2011), quienes sostienen que el género Argyrochosma comprende dos grandes grupos monofiléticos: uno exclusivamente no farinoso y otro mayormente farinoso, en el cual se incluye a Argyrochosma nivea. Solo Argyrochosma nivea var. flava sería monofilética en tanto que Argyrochosma nivea var. nivea y Argyrochosma nivea var. tenera integran otro clado independiente que no tienen resueltas sus relaciones de parentesco. 
En Huperzia saururus, las excrecencias globosas que observamos sobre la cutícula son las que Rolleri-de-Dougherty(1972) describió como "papilas en las paredes celulares epidérmicas foliares". Estas estructuras papiliformes están ausentes en otras especies de Huperzia de Brasil analizadas por Borges Pita et al. (2006).

Un carácter que resultó interesante en distintos géneros es la presencia de idioblastos esclerenquimáticos, cuya presencia es frecuentemente utilizada en la taxonomía de las Pteridáceas (Graçano et al. 2001), especialmente en las especies de Adiantum. En este género, se ha verificado la presencia de unas pocas células muy lignificadas, que interrumpen la epidermis a nivel de las venas, continuándose en torno al hacecillo formando una vaina completa, denominada "endodermis" por Wylie (1948). En cambio, en otros taxones, como en Elaphoglossum gayanum y las especies de Anemia, las células esclerenquimatosas de la epidermis protruyen hacia el exterior en tanto que en Huperzia saururus y Lycopodium thyoides, los idioblastos lignificados están aislados.

Caracteres diagnósticos para un control de calidad La información que se brinda en este trabajo resultó relevante para diferenciar las especies de helechos y licófitas, según se puede apreciar en la clave que se aporta. De todos los caracteres observados, merecen especial atención para un buen control de calidad, en orden de importancia: el indumento (tipo de escamas y de pelos), tipo de estomas, disposición de los estomas respecto del resto de la epidermis y su distribución en epifilo e hipofilo, características de los indusios/pseudoindusios, forma de las células en vistas superficial y en transcorte, sustancias adcrustantes $\mathrm{y}$ engrosamientos de la pared celular, presencia y características epidérmicas de las expansiones alares, presencia de lenticelas e hidatodos.

De todos los helechos y licófitas de Córdoba citadas en la literatura con propiedades medicinales (Barboza et al. 2009), se comercializan las especies de Equisetum, Adiantum, Cheilanthes, Anemia y Huperzia (Luján \& Morero, obs. pers.). Para estas especies, es importante contar con adecuados caracteres diagnósticos que permitan su identificación en las muestras comerciales picadas o molidas. En este sentido, fue importante encontrar marcadas diferencias, particularmente entre las especies de Adiantum que se expenden picadas y mezcladas bajo un mismo rótulo y nombre vulgar ("culandrillos").
Morfológicamente estas especies son similares, más aún cuando aparecen trozadas; en estos casos, la forma de los pseudoindusios y su entramado celular, los tipos de pelos eglandulares y no glandulares y la forma de las células en el epi- e hipofilo fueron los caracteres que resultaron más útiles para diferenciarlas en estas condiciones. Conviene aclarar que si bien las escamas rizomáticas contribuyen en la diferenciación de los taxones (Giúdice 1999), en los controles de calidad este rasgo no puede ser considerado ya que sólo se expenden las frondes.

Con respecto a Cheilanthes y Anemia, la situación es similar a la anterior. Cheilanthes myriophylla, Anemia tomentosa y Anemia australis comparten el mismo nombre vulgar de "doradilla" (Sota 1977, Barboza et al. 2009). Estos tres taxones se comercializan picados. Todas las muestras controladas son expedidas bajo el nombre de "doradilla", algunas sin el nombre científico y otras bajo Anemia tomentosa. El control de calidad aplicado con los caracteres epidérmicos de este estudio reveló que estas especies se venden separadamente o bien mezcladas en el mismo envase. Aquí, las escamas de los raquis y los pelos y tipos de estomas de la lámina fueron los que permitieron tomar decisiones sobre la identidad de las especies.

Desde el punto de vista morfohistológico, se describen por primera vez pelos y escamas inéditos o poco frecuentes: pelos de aspecto escamoso, pelos ramificados cónicos y diversas microescamas. Asimismo, se citan distintos tipos de estomas no descriptos con anterioridad para los taxones estudiados. Por otra parte, la información morfohistológica provista a través de las descripciones por especie, queda disponible para ser incorporada a Libros Oficiales (Farmacopeas) o cuando una especie es registrada como un agente fitoterapéutico.

Desde el punto de vista taxonómico, el indumento y los tipos de estomas fueron los caracteres más significativos para diferenciar taxones a nivel específico e infraespecífico en tanto que la forma de las células, las características de la pared celular y la cutícula de las células epidérmicas propiamente dichas, quedan más relegados por ser caracteres más uniformes en la mayoría de los helechos estudiados.

Desde el punto de vista del aporte al control de calidad, la caracterización epidérmica de los helechos medicinales que crecen en Córdoba, resumida en la clave, demostró ser una herramienta eficaz para la identificación de una especie cuando la droga vegetal se encuentra fragmentada o pulverizada. 


\section{Agradecimientos}

Expresamos nuestro agradecimiento a los Curadores de los herbarios del Museo Botánico de Córdoba (CORD) y de la Universidad de Río Cuarto (RCV; RIOC), por poner a nuestra disposición parte de los materiales estudiados. Asimismo, hacemos extensivo nuestro reconocimiento a los dibujantes L. Ribulgo y P. Peralta por la confección de las ilustraciones, al Arq. J. Giorgis por el diseño y diagramación de las fotografías y a los revisores anónimos por las sugerencias realizadas para mejorar sustancialmente el manuscrito. Este trabajo fue financiado por la Secretaría de Ciencia y Tecnología de la Universidad Nacional de Córdoba (Secyt-UNC).

\section{Literatura citada}

Arana, M.D., Ponce, M. \& Vischi, N.B. 2004. Sinopsis de los helechos y grupos relacionados (Pteridophyta) de la Provincia de Córdoba, Argentina. Boletín de la Sociedad Argentina de Botánica 39: 89-114.

Barboza, G., Cantero, J.J., Núnez, C. \& Ariza-Espinar, L. (eds.). 2006. Flora Medicinal de la Provincia de Córdoba (Argentina). Pteridofitas y Antófitas silvestres o naturalizadas. Museo Botánico, Córdoba.

Barboza, G., Cantero, J.J., Núñez, C., Pacciaroni, A. \& Ariza-Espinar, L. 2009. Medicinal Plants: A general review and a phytochemical and ethnopharmacological screening of the native Argentinean Flora. Kurtziana 34: 7-365.

Bianco, C.A. \& Cantero, J.J. 1988. Las Plantas Vasculares del suroeste de la provincia de Córdoba. Parte IV. Pteridophyta. Revista de la Universidad Nacional de Río Cuarto 8: 5-55.

Borges Pita, P., Menezes, N.L. \& Prado, J. 2006. Morfologia externa e interna de raiz e caule de espécies de Huperzia Bernh. (Lycopodiaceae-Pteridophyta) do Brasil. Hoehnea 33: 495-510.

Chambers, T.C. \& Farrat, P.A. 1991. A re-examination of the genus Cheilanthes (Adiantaceae) in Australia. Telopea 4: 509-557.

Chuang, Y.Y. \& Liu, H.Y. 2003. Leaf epidermal morphology and its systematic implications in Taiwan Pteridaceae. Taiwania 48: 60-71.

Conticello, L., Gandullo, R., Bustamante, A. \& Tartaglia, C. 1997. El uso de plantas medicinales por la comunidad mapuche de San Martín de los Andes, Neuquén (Argentina). Parodiana 10: 165-180.

D’ Ambrogio-de-Argüeso, A. 1986. Manual de técnicas en histología vegetal. Hemiferio Sur, Buenos Aires.

Di Fulvio, E. 1956. Observaciones morfológicas y taxonómicas sobre las especies de Azolla del centro de Argentina. Revista de la Facultad de Ciencias Exactas, Físicas y Naturales, Córdoba 18: 337-354.
Di Fulvio, T.E. \& Dottori, N. 1995. Contribución al conocimiento de tricomas y emergencias en Hidrophyllaceae. Clasificación y consideraciones taxonómicas. Kurtziana 24: 19-64.

Durán, M.L. 1997. Estudios morfológicos, taxonómicos y biosistemáticos en el género Blechnum L. Blechnaceae-Pteridophyta. Tesis Doctoral, Universidad Nacional de Córdoba, Córdoba.

Farmacopea Nacional Argentina. 1978. 6 ed. Ministerio de Bienestar Social, Buenos Aires.

Filipov, A. 1997. La farmacopea natural en los sistemas terapéuticos de los indígenas Pilagá. Parodiana 10: 35-74.

Font Quer, P. 1993. Plantas Medicinales I-III. Labor, Barcelona.

Fryns-Claessens, E. \& Van Cotthem, W. 1973. A new classification of the ontogenetic types of stomata. The Botanical Review 39: 71-137.

Gabriel y Galán, J.M., Prada, C. \& Rolleri, C. 2008. Spore germination, gametophyte morphology and sexual expression of Polypodium feuillei. Gayana, Botánica 65: 1-9.

Ganem, M.A., Giúdice, G.E., Luna, M.L. \& Sota, E.R. 2007. Revisión del grupo "Asplenium squamosum" (Aspleniaceae) en América. Candollea 62: 149-156.

Gifford, E.M. \& Foster, A.S. 1989. Morphology and evolution of Vascular Plants. 3 ed. W. H. Freeman and Company, New York.

Giúdice, G.E. \& Nieto, M.L. 1994. Morfología, sistemática y distribución geográfica de las especies bonaerenses del género Adiantum (Adiantaceae, Pteridophyta). Revista del Museo de La Plata, nueva serie, Botánica 14: 221-241.

Giúdice, G.E. 1999. Sinopsis de las especies argentinas del género Adiantum (Pteridaceae, Pteridophyta). Darwiniana 37: 279-300.

Graçano, D., Alves-Azevedo, A. \& Prado, J. 2001. Anatomia foliar das espécies de Pteridaceae do Parque Estadual do Rio Doce (PERD) MG. Revista Brasileira de Botânica 24: 333-347.

Guantay, M.E. \& Hernández-de-Terán, M. 1995. Estudio morfoanatómico de las especies del género Elaphoglossum Schott de Tucumán. Lilloa 38: 73-84.

Haberlandt, G. 1882. Vergleichende Anatomie des assimilatorischen Gewebesystems der Pflanzen. Jahrbücher für wissenschaftliche Botanik13: 74-188.

Hernández-de-Terán, M.A. 1992. Análisis histofoliar comparado de las especies tucumanas de Cheilanthes Swartz (Pteridophyta, Adiantaceae). Lilloa 38: 33-38.

Hieronymus, G. 1882. Plantae diaphoricae Florae Argentinae. Kraft, Buenos Aires.

Hurrell, J. \& Sota, E.R. 1996. Etnobotánica de de las Pteridófitas de los pastizales de altura de Santa Victoria (Salta, Argentina), Revista del Museo La Plata, nueva serie, Botánica 14: 343-364. 
Knobloch, I.W., Rasmussen, H.P. \& Johnson, W.S. 1975. Scanning electron microscopy of trichomes of Cheilanthes (Sinopteridaceae). Brittonia 27: 245-250.

Lahitte, H., Hurrell, J., Belgrano, M., Jankowski, L., Helova, P. \& Mehltrete, K. 1998. Plantas Medicinales Rioplatenses. Lola, Buenos Aires.

Lavalle, M. C. \& Rodríguez, M. 2010. Indumento y modelos epidérmicos en especies argentinas de Elaphoglossum (Dryopteridaceae-Pteridophyta). Boletín de la Sociedad Argentina de Botánica 45: 245-256

Lellinger, D.B. 2002. A modern multilingual glossary of taxonomic Pteridology. Pteridologia 2: 1-263.

Link-Pérez, M.A. \& James-Hickey, R. 2011. Revision of Adiantopsis radiata (Pteridaceae) with descriptions of new taxa with palmately compound laminae. Systematic Botany 36: 565-582.

Looser, G. \& Rodríguez, R. 2004. Los helechos medicinales de Chile y sus nombres vulgares. Gayana, Botánica 61:1-5.

Luján, M.C. \& Barboza, G. 2008. Control de calidad botánico e higiénico-sanitario de muestras comerciales usadas como droga cruda en Argentina. Arnaldoa 15: 109-125.

Luján, M.C., Barboza, G., Weler-de-Serra, S. \& Ariza Espinar, L. 2000. Control de calidad en dos helechos medicinales y su inserción en el mercado local. Studia Botánica 19: 75-94.

Luján, M.C., Morero, R., Bonzani, N. \& Barboza, G. 2007. Sobre la identidad de algunos helechos medicinales que se comercializan en Córdoba (Argentina). Boletín Latinoamericano y del Caribe de Plantas Medicinales y Aromáticas 6: 376-377.

Martínez, G.J. 2010. Las plantas en la medicina tradicional de las sierras de Córdoba. Un recorrido por la cultura campesina de Paravachasca y Calamuchita. Ediciones del Copista, Argentina

Martínez Crovetto, R. 1981a. Las plantas utilizadas en medicina popular en el noroeste de Corrientes (Rep. Arg.). Miscelánea (Tucumán) 69: 1-139.

Martínez Crovetto, R. 1981b. Plantas reguladoras de la fecundidad utilizadas en la medicina popular del nordeste argentino. Parodiana 1: 97-137.

Mickel, J.T. \& Lersten, N.R. 1967. Floating stomata (adetotomy) in ferns: Distribution and ontogeny. American Journal of Botany 54: 1181-1185.

Morero, R., Giorgis, M.A., Sota, E. R. \& Barboza, G. 2006. Nuevas citas de Pteridófitas para el Distrito Chaqueño Serrano de Córdoba (Argentina). Boletín de la Sociedad Argentina de Botánica 41: 327-330.

Murillo, M.T. 1968. Blechnum subgénero Blechnum en Sur América, con especial referencia a las especies de Colombia. Nova Hedwigia 16: 329-366.

Murillo, M. 1983. Usos de los helechos en Suramérica con especial referencia a Colombia. Universidad Nacional de Colombia, Bogotá.
Navarrete, H., León, B., Gonzáles, J., Avilés, D. K., Salazar Recaro, J., Mellado, F., Alban, J. \& Øllgaard, B. 2006. Helechos. In: M. Moraes, B. Øllgaard, L.P. Kvist, F. Borchsenius \& H. Balslev (eds.). Botánica Económica de los Andes Centrales Universidad Mayor de San Andrés, La Paz. v.1, parte 5, pp. 385-411.

Ogura, Y. 1972. Comparative anatomy of vegetative organs of the Pteridophytes. In: K. Linsbauer, G. Tischler \& A. Pascher (eds.). Encyclopedia of Plant Anatomy Gebrüder Borntraeger, Berlín, v. 7, pp. 1-502.

Pacciaroni A., Santillán S., Morero R., Luján L., Barboza G. \& Sosa, V. 2009. Estudio farmacobotánico y químico de los "helechos machos" de Argentina. In: XVIII Congreso Internacional Italo-Latinoamericano de Etnomedicina “Juan Tomás Roig y Mesa” y VIII Taller Internacional "Química de los productos naturales", La Habana, pp. 2 (Anexo).

Payne, W.W. 1978. A glossary of plant hair terminology. Brittonia 30: 239-255.

Ponce, M.M. \& Morbelli, M.A. 1989. The Cheilanthes dichotoma group of South America. America Fern Journal 79: 127-135.

Ponce, M., Mehltreter, K. \& Sota, E.R. 2002. Análisis biogeográfico de la diversidad pteridofítica en Argentina y Chile continental. Revista Chilena de Historia Natural 75: 703-717.

Prantl, K. 1881. Vorläufige Mitteilung über die Morphologie, Anatomie und Systematik der Schizaeaceen. Botanische Jahrbücher für Systematik 2: 297-303.

Quirk, H., Chambers, T.C. \& Regan, M. 1983. The fern genus Cheilanthes in Australia. Australian Journal of Botany 31: 501-553.

Ribeiro, M.L.R.C., Guerra-Santos, M. \& GomesMoraes, M. 2007. Leaf anatomy of two Anemia Sw. species (Schizaeaceae-Pteridophyte) from a rocky outcrop in Niterói, Rio de Janeiro, Brazil. Revista Brasileira de Botânica 30: 695-702.

Roig, F. 2002. Flora Medicinal Mendocina. Las plantas medicinales y aromáticas de la provincia de Mendoza (Argentina). Ediunc, Mendoza.

Rolleri de Dougherty, C. 1972. Morfología comparada de las especies de "Lycopodium" (Lycopodiaceae-Pteridophyta) del Noroeste de Argentina. Revista del Museo de La Plata, nueva serie, Botánica 68: 223-317.

Rolleri, C.H. 1976. Estudio de la morfología foliar comparada de especies e híbridos interespecíficos del género Blechnum subgénero Blechnum (BlechnaceaePteridophyta). Boletín de la Sociedad Argentina de Botánica 17: 5-24.

Rolleri, C.H. \& Prada, C. 2006a. Catálogo comentado de las especies de Blechnum L. (Blechnaceae, Pteridophyta) de Mesoamérica y Sudamérica. Anales del Jardín Botánico de Madrid 63: 67-106. 
Rolleri, C.H. \& Prada, C. 2006b. Revisión de los grupos de especies del género Blechnum (BlechnaceaePteridophyta): El grupo B. penna-marina. Acta Botánica Malacitana 31: 7-50.

Salvo-Tierra, E. 1990. Guía de helechos de la Península Ibérica y Baleares. Ediciones Pirámide, Madrid.

Sen, U. \& De, B. 1992. Structure and ontogeny of stomata in ferns. Blumea 37: 239-261.

Sigel, E.M., Windham, M.D., Huiet, L., Yatskievych, G. \& Pryer, K.M. 2011. Species relationships and farina evolution in the Cheilanthoid Fern Genus Argyrochosma (Pteridaceae). Systematic Botany 36: 554-564.

Sylvestre, L.S. \& Ponce, M.M. 2008. Pteridophyta. In: Zuloaga, F.O., Morrone, O. \& Belgrano, M. (eds.). Catálogo de las Plantas Vasculares del Cono Sur. Monograph of the Missouri Botanical Garden (USA) 107: 1-161.

Smith, A.R., Kreier, H.P., Haufler, C.H., Ranker, T.A. \& Schenider, H. 2006. Serpocaulon (Polypodiaceae), a new genus segregated from Polypodium. Taxon 55: 919-930.

Sota, E.R. 1960. Polypodiaceae y Grammitidaceae Argentinas. Opera Lilloana 5: 1-229.

Sota, E.R. 1966. Revisión de las especies americanas del grupo Polypodium squamatum L. (Polypodiaceae). Revista del Museo de La Plata, nueva serie, Botánica 10: 69-186.

Sota, E.R. 1972a. Notas sobre especies austrosudamericanas del género Blechnum L. (Blechnaceae-Pteridophyta) III. Boletín de la Sociedad Argentina de Botánica14: 177-184.

Sota, E.R. 1972b. Notas sobre especies austrosudamericanas del género Blechnum L. (Blechnaceae-Pteridophyta), IV. Boletín de la Sociedad Argentina de Botánica 14: 185-189.

Sota, E.R. 1977. Pteridophyta. In: A.L. Cabrera (dir.). Flora de la Provincia de Jujuy, v. 2, Colección Científica, Instituto Nacional de Tecnología Agropecuaria, Buenos Aires, pp. 1-275.
Sota, E.R., Ponce, M.M., Morbelli, M.A. \& Cassá de Pazos, L. 1998. Pteridophyta. In: M. N. Correa (ed.). Flora Patagónica, v. 1, Colección Científica, Instituto Nacional de Tecnología Agropecuaria, Buenos Aires, pp. 282-369.

Strasburger, E., Noll, F., Schenck, H. \& Schimper, A.F.W. 1994. Tratado de Botánica (Actualizado por P. Sitte, H. Ziegler, F. Enrendorfer \& A. Bresinsky): Omega, Barcelona.

Sundue, M.A. 2010. A morphological cladistic. Analysis of Terpsichore (Polypodiaceae). Sistematic Botany 35: 716-729.

Sundue, M.A., Islam, M.B., Ranker, T.A. 2010. Systematics of Grammitid Ferns (Polypodiaceae): Using morphology and plastid sequence data to resolve the circumscriptions of Melpomene and the polyphyletic genera Lellingeria and Terpsichore. Systematic Botany 35: 701-715.

Theobald, W.L., Krahulik, J.L. \& Rollins, R.C. 1979. Trichome description and classification. In: C.R. Metcalfe \& L. Chalk (eds.). Anatomy of the Dicotyledons, v.1, Clarendon Press, Oxford, pp. 40-53.

Tryon, R.M. \& Tryon, A.F. 1982. Ferns and allied plants, with special reference to Tropical America. Springer Verlag, New York.

Van Cotthem, W.R.J. 1970a. Comparative morphological study of the stomata in the Filicopsida. Bulletin du Jardin Botanique National de Belgique 40: 81-239.

Van Cotthem, W.R.J. 1970b. A classification of stomatal types. Botanical Journal of the Linnean Society 63: 235-246.

Van Cotthem, W.R.J. 1973. Stomatal types and systematics. In: J.A. Crabbe \& B.A. Thomas (eds.). The phylogeny and classification of the ferns. Botanical Journal of the Linnean Society 67: 59-71.

Wilkinson, R.B. 1979. The plant surface (mainly leaf). In: C.R. Metcalfe \& L. Chalk (eds.). Anatomy of the Dicotyledons, v.1. Clarendon Press, Oxford, pp. 27-165.

Wylie, R.B. 1948. The dominant role of the epidermis in leaves of Adiantum. American Journal of Botany 35: 465-473. 